FACULDADE DE FILOSOFIA, LETRAS E CIÊNCIAS HUMANAS DEPARTAMENTO DE LETRAS MODERNAS

ESTUDOS LINGUÍSTICOS E LITERÁRIOS EM INGLÊS

\title{
Utopia, feminismo e resignação \\ em The left Hand of Darkness e The Handmaid's Tale
}

Ana Rüsche

Tese apresentada ao Programa de Pós-Graduação em Estudos Literários e Linguísticos em Inglês do Departamento de Letras Modernas da Faculdade de Filosofia, Letras e Ciências Humanas da Universidade de São Paulo para a obtenção do título de Doutora em Letras.

Orientadora: Profa. Dra. Maria Elisa Burgos Pereira da Silva Cevasco

Versão corrigida

São Paulo

2015 
Autorizo a reprodução e divulgação total ou parcial deste trabalho, por qualquer meio convencional ou eletrônico, para fins de estudo e pesquisa, desde que citada a fonte.

Catalogação na Publicação Serviço de Biblioteca e Documentação

Faculdade de Filosofia, Letras e Ciências Humanas da Universidade de São Paulo

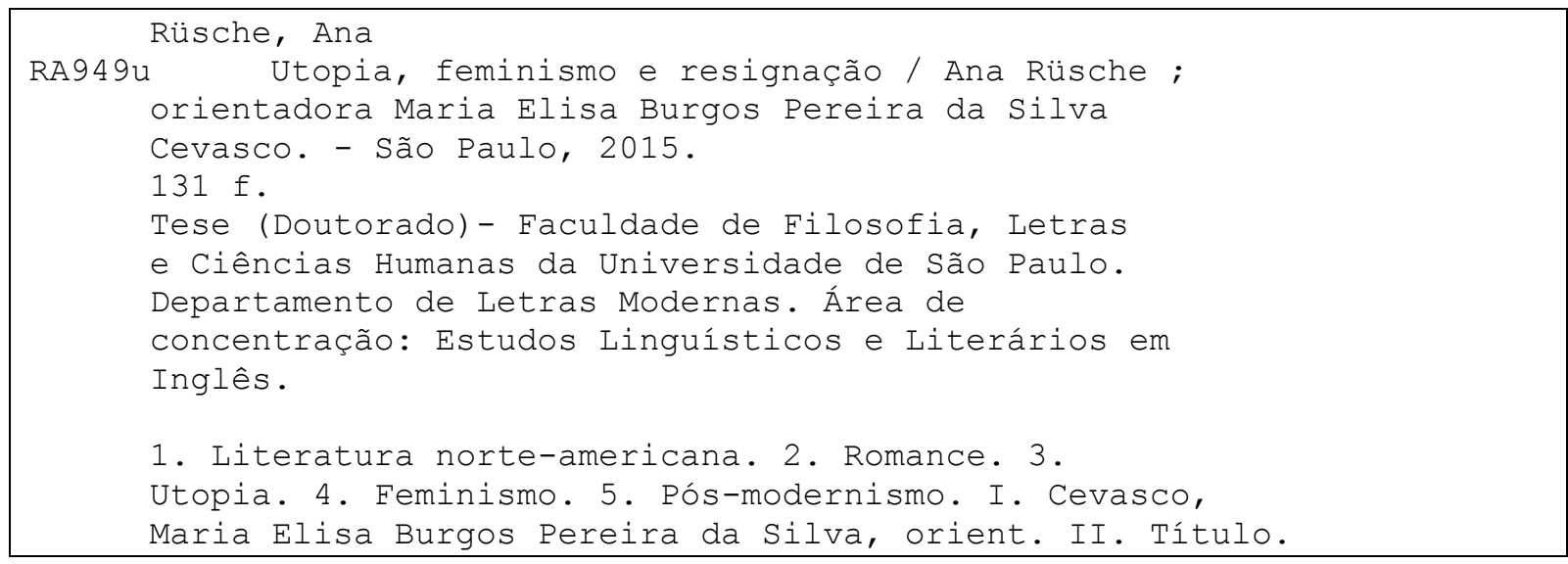


RÜSCHE, Ana. Utopia, feminismo e resignação em The left Hand of Darkness e The Handmaid's Tale. Tese apresentada ao Programa de Pós-Graduação em Estudos Literários e Linguísticos em Inglês do Departamento de Letras Modernas da Faculdade de Filosofia, Letras e Ciências Humanas da Universidade de São Paulo para a obtenção do título de Doutora em Letras. 
Para todas as pessoas que, de vez em quando, acordam com lembranças vagas, como se tivessem finalmente em sonhos avistado a ilha da Utopia. 


\section{AGRADECIMENTOS}

Aos meus pais, ao Beto e ao Canek;

À Maria Elisa Cevasco, que me orientou com sinceridade e bom humor invejáveis. Aos membros da banca, Profs. Drs. Marcos Cesar de Paula Soares, Maria Silvia Betti, Isabel Loureiro e José Corrêa Leite Jr, cujos comentários e críticas foram úteis e pertinentes.

A Jeanne Callegari, Karla Lima, Rafael Rocha Daud, Roberto Rüsche e Thiago Tavares Vidal, que tiveram uma atuação decisiva nestes escritos, seja revisando, me auxiliando na pesquisa da fortuna crítica, conferindo traduções e dando conselhos (a existência de qualquer deslize pequeno ou grave na pesquisa e redação se deve unicamente a minha pessoa). Também faço o agradecimento à Ana Paula Ferraz e ao Elton Furnaletto, que me deram bons conselhos sobre os futuros deste trabalho.

Aos colegas da Fundação Rosa Luxemburgo, Instituto Martius-Staden e KQi Produções, que sempre me apoiaram nesta empreitada, mesmo não a entendendo muito bem;

Às Blogueiras Feministas, Pedalinas, Hildegarda e Quatro Peixes, coletivos que me auxiliaram a compreender questões feministas no cotidiano e pela privilegiada via do respeito e da amizade;

Aos grupos de criação e discussão literária $A$ Narrativa revela o sentido, sem cometer o erro de defini-lo, Fantastika, Frio \& fúria e Utopia na padaria, que me fizeram pensar melhor a respeito das obras estudadas;

Aos grupos de criadores Pequenos Punks Pôneis, Reprimidos da ABIN e Telegram, queridos companheiros do insone, ruidoso e amoroso Partido da Utopia. 
Hard times are coming, when we'll be wanting the voices of writers who can see alternatives to how we live now, can see through our fear-stricken society and its obsessive technologies to other ways of being, and even imagine real grounds for hope. We'll need writers who can remember freedom - poets, visionaries - realists of a larger reality.

Right now, we need writers who know the difference between production of a market commodity and the practice of an art. Developing written material to suit sales strategies in order to maximise corporate profit and advertising revenue is not the same thing as responsible book publishing or authorship.

Yet I see sales departments given control over editorial. I see my own publishers, in a silly panic of ignorance and greed, charging public libraries for an e-book six or seven times more than they charge customers. We just saw a profiteer try to punish a publisher for disobedience, and writers threatened by corporate fatwa. And I see a lot of us, the producers, who write the books and make the books, accepting this - letting commodity profiteers sell us like deodorant, and tell us what to publish, what to write.

Books aren't just commodities; the profit motive is often in conflict with the aims of art. We live in capitalism, its power seems inescapable - but then, so did the divine right of kings. Any human power can be resisted and changed by human beings. Resistance and change often begin in art. Very often in our art, the art of words.

I've had a long career as a writer, and a good one, in good company. Here at the end of it, I don't want to watch American literature get sold down the river. We who live by writing and publishing want and should demand our fair share of the proceeds; but the name of our beautiful reward isn't profit. Its name is freedom.

\section{URSULA K. LE GUIN}

Trecho do discurso de agradecimento da escritora por ocasião da entrega do National Book Awards em 20 de novembro de 2014. 


\section{RESUMO}

\section{RÜSCHE, Ana. Utopia, feminismo e resignação em The left Hand of Darkness e The} Handmaid's Tale. 2015. 131 f. (Tese) Faculdade de Filosofia, Letras e Ciências Humanas da Universidade de São Paulo, São Paulo, 2015.

Os romances norte-americanos The left Hand of Darkness de Usula Le Guin (1969) e The Handmaid's Tale de Margaret Atwood (1985) traduzem os anseios dos ideários políticos e feministas em seus momentos de publicação. As obras são consideradas, respectivamente, um romance utópico do gênero ficção científica e um romance distópico que se tornou best seller. The left Hand of Darkness coloca, em fragmentos, a questão do planeta Gethen, que se vê diante de uma ginada histórica: ingressar ou não, figurando como uma nação periférica, no Ekumen, uma liga interplanetária. O planeta é habitado por seres ambissexuais e recebe a visita do Enviado, um homem, o incumbindo em trazer esta questão. The Handmaid's Tale traz relatos da Aia Offred, residente de Gilead, nação que seria um fantasmagórico duplo dos Estados Unidos dos anos de 1980, onde se instituiu um governo teocrático, abolindo os direitos mais básicos de todas as mulheres, embora restem mantidas a propriedade privada e a produção capitalista. Offred é uma Aia, o seu útero é tutelado por este Estado e seus relatos foram reconstituídos por dois professores em um simpósio acadêmico no ano de 2195. No trabalho, discute-se a impossibilidade da configuração da utopia nos romances, observando-se as teorias feministas e estudos de gênero na segunda metade do século XX; as formas literárias dentro da noção do que seria o romance no pósmodernismo; a crítica da representação e suas funções ideológicas e a emergência de impulsos utópicos em produtos da cultura de massa, tendo em vista a medologia desenvolvida pela crítica materialista, com ênfase nas análises de Fredric Jameson na obra Archaeologies of the future: the desire called utopia and other science fictions.

Palavras-chave: Literatura norte-americana. Romance. Utopia. Feminismo. Pós-modernismo. 


\begin{abstract}
The North American novels The Left Hand of Darkness by Usula Le Guin (1969) and The Handmaid's Tale by Margaret Atwood (1985) reflect the political and feminist aspirations at the time they were each published. They are considered, respectively, a science-fiction utopian novel and a best-seller dystopian novel. The Left Hand of Darkness presents, in a fragmented way, the question faced by the planet Gethen at a turning point in its history: to join or not, as a peripheral nation, the interplanetary league known as 'Ekumen'. The planet is inhabited by "ambisexuals" beings and receives a visit from "the Envoy", a male, who is tasked with presenting this choice to Gethen. The Handmaid's Tale tells the story of the handmaid Offred, a resident of Gilead, a nation that represents a phantasmagoric version of the United States in the 1980s, where a theocratic government was stablished, suppresing the most basic rights of all women, while mantaining capitalism and private property. Offred is a handmaid, which uterus is managed by this state and her story is reconstituted by two professors in an academic symposium in the year 2195. In this paper, I discuss the impossibility of the utopia in these novels, taking in account feminist theory and gender studies in the second half of the twentieth century; literary forms and the idea of what would constitute the postmodern novel; the critique of representation and its ideological functions and the emergence of utopic impulses in the products of mass culture, having in mind the to metodology developed by the materialist critique, with emphasis in Fredric Jameson and his work Archaeologies of the future: the desire called utopia and other science fictions.
\end{abstract}

Keywords: North American Literature. Novel. Utopia. Feminism. Postmodernism. 


\section{LISTA DE SIGLAS}

EUA Estados Unidos da América

FC ficção científica

HT The Handmaid's Tale

LHD The Left Hand of Darkness

ONU Organização das Nações Unidas 


\section{Sumário}

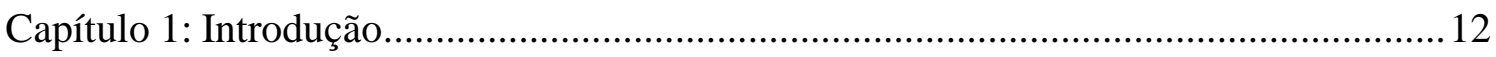

1.1 Utopia e resignação, uma dialética da insistência ..............................................12

1.2 A forma dos romances e a força da tradição .........................................................18

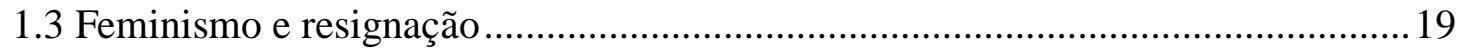

1.4 Sobre o contexto no qual a pesquisa foi realizada ...........................................21

1.5 Dados bibliográficos resumidos sobre as autoras ............................................2 23

Capítulo 2 - The left Hand of Darkness: utopia e imaginação ......................................26

$2.1 \mathrm{O}$ ciclo hainiano: anticapitalismo e pacifismo..................................................26

2.2 Três momentos da crítica: de utopia política aos estudos de gênero.......................29

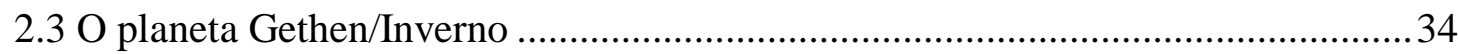

2.4 A forma do romance e as possibilidades da imaginação utópica ............................37

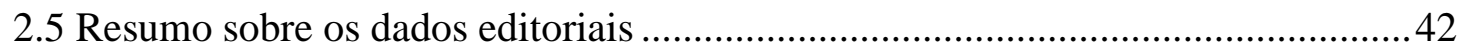

Capítulo 3 - The Handmaid`s Tale: nostalgia e resignação ...........................................43

3.1 As narrativas que formam "O conto da aia".....................................................43

3.2 Vertentes críticas sobre o romance: backlash e utopia.......................................48

3.3 A nostalgia e o tabu: poderiam os EUA ter originado Gilead? ..............................53

3.4 A resignação como princípio de composição ......................................................58 
3.5 Alguns dados sobre a publicação

Capítulo 4 - Feminismos e teorias de gênero nos dois romances.........

4.1 Gender, questão comum aos dois romances

4.2 Os impactos causados pela alteração do status da mulher 66

4.3 A segunda onda: narrativas sobre as teorias feministas 68

4.4 As teorias feministas e o mais novo espírito do capitalismo .72

4.5 Que ele era uma mulher, assim como era um homem 78

4.6 O conceito de shiftgrethor. 84

4.7 HT, um romance recepcionado como feminista. 86

4.8 HT, imaginar o feminismo somente dentro do possível

Capítulo 5 - Forma, funções ideológicas e impulsos subjacentes .96

5.1 O romance como gênero ambivalente e acomodação de novos materiais .96

5.2 Um método capaz de fazer justiça 100

5.3. Descontinuidades de gêneros e a força da tradição em LHD 103

5.4 Resignação e a emergência da solidariedade

Capítulo 6: Considerações finais. 119

Bibliografia 121 


\section{Capítulo 1: Introdução}

\subsection{Utopia e resignação, uma dialética da insistência}

Não deixa de ser curioso que gêneros literários com proposta de refletirem sobre mudanças sociais possuam como característica justamente as limitações nas configurações de suas utopias - aqui nos referimos aos gêneros denominados "ficção científica", "ficção especulativa" e "ficção política". Mesmo tendo à disposição todo o livre-arbítrio que estas formas artísticas presumem, a imaginação parece que encontra entraves no momento em que estas visões fantásticas são relatadas: aparentemente, há uma imensa liberdade criativa - estão autorizadas as viagens ao espaço e às mais longínquas civilizações alienígenas; os retornos ao passado são possíveis, assim como conhecer o futuro; a biologia que conhecemos pode receber novas regras; golpes de estado ocorrem a qualquer momento e impõem novas formas de organização social. Entretanto, esta liberdade criativa se limita, estacando na fronteira do "conhecido". Há um desejo premente pelo surgimento de novas ordens sociais, mas ainda não é possível pensar em como se dariam concretamente no atual horizonte histórico. Aqui se faz então a proposta de analisar estes tipos de texto pelo que não conseguem dizer ou ainda não logram apresentar. Por que a utopia fracassa quando é nela em que mais se pensaria? Qual o motivo de não se conseguir imaginar o mundo perfeito se, ao mesmo tempo, este desejo não sai da ordem do dia?

O presente trabalho procura contribuir com o estudo de uma questão situada no recorte cronológico que se inicia na segunda metade do século $\mathrm{XX}$ e que é recorrente na literatura produzida na América do Norte: o aparecimento, com bastante insistência, de romances que tratam de utopias e distopias, que acabam tendo suas configurações imaginativas limitadas ao serem formalizadas. A indagação central desta tese gira em torno de se refletir sobre o porquê de certas literaturas, que possuem a utopia como parte constituinte das características do gênero - como o são a ficção científica e a ficção política, resignarem-se e não conseguirem perfazer suas utopias em uma obra literária. Dentro do tema, os limites à configuração de utopias e distopia, escolheu-se uma delimitação - problematizar as tentativas de construir utopias e distopias em romances que trazem o ideal feminista. 
A atual proposta é conjecturar sobre o fracasso da imaginação utópica quando ocorre a idealização de uma sociedade em que haveria paridade entre homens e mulheres. O campo de prova são duas obras relevantes à produção de língua inglesa: The left hand of darkness, de Ursula Le Guin, publicado em 1969, e The handmaid's tale, de Margaret Atwood, publicado em 1985, que serão esmiuçadas nos Capítulos 2 e 3.

Para contextualizar a proposta, é importante lembrar que a devastação deixada por duas guerras mundiais e uma crise econômica severa no intervalo entre os dois conflitos marcaram, de forma definitiva, a imaginação ocidental sobre o que poderia ser o outro mundo possível - uma sociedade mais justa, mais equânime e respeitosa com todas as formas de vida.

Na segunda metade do século $\mathrm{XX}$, quando se origina o tipo de literatura em língua inglesa que aqui se investiga, o trauma é instaurado. Por um lado, com a Guerra Fria, as "ideias vermelhas" são alastradas e combatidas na América do Norte, inclusive com forte arsenal estatal de McCarthy. Por outro, com a ciência do que ocorria sob o regime totalitário da URSS, a "utopia teria sido convertida em sinônimo de estalinismo e acabava por designar um programa que descuidava da fragilidade humana e o pecado original" (JAMESON, 2005), sugerindo um programa com características pouco animadoras: autoritário, burocrático, não solidário, ignorando a fragilidade ecológica, um rolo compressor ideológico assentando o asfalto de uma nova rua de mão única para o leste.

No campo cultural, surge o que se convenciona chamar de pós-modernismo, que pode ser descrito em termos de uma hegemonia cultural (JAMESON, 2006a, p. 176), sem sugerir, contudo, que seja homogêneo, massificado e uniforme, pois seria como um campo de força em que coexistem outras formas de produção cultural - residuais, resistentes e heterogêneas (por exemplo, de grupos marginais, de linguagens residuais ou de culturas emergentes radicalmente distintas), tendo a dinâmica de tentar dominar e incorporar estas formas de alteridade, de maneira a absorvêlas ao seu modo. Nas palavras de Jameson:

(...) devo lembrar ao leitor o óbvio, a saber, que a nova cultura pós-moderna global, ainda que americana, é expressão interna e superestrutural de uma nova era de dominação, militar e econômica, dos Estados Unidos sobre o resto do mundo. (2006, p. 31)

A tarefa de investigar impulsos utópicos acaba por ser útil à crítica do período pósmoderno, pois se trata de uma tentativa de problematizar a ideia de "fim das ideologias", embora 
essa tentativa não possa constituir por si só uma política. O período é marcado por características que aprofundam aspectos já embrionários no modernismo, sendo que dois possuem importância para este trabalho: uma nova falta de profundidade (o fim, por exemplo, do estilo único, da manifestação vinda do âmago de um sujeito que agora estaria "morto") e um enfraquecimento da noção de historicidade. Ambos os aspectos afetariam relações públicas e privadas, unindo-se em um novo tipo de matriz emocional, em "uma profunda relação constitutiva de tudo isso com a nova tecnologia" (JAMESON, 2006a, p. 32). Mais do que efetuar uma condenação ou um elogio moral ao pós-modernismo, parece ser mais apropriado refletir a respeito desta nova produção cultural a partir da hipótese de estar em curso uma modificação na própria cultura.

Nas literaturas em análise, o acirramento do espírito dos tempos ora assiste à emergência breve de uma alteridade utópica, ora se fortalece em distopias. Especificamente nas utopias, por mais que fracassem em sua constituição, exprime-se um desejo pelo aparecimento de novas ordens sociais, mesmo que não seja mais possível pensar em como se dariam. Perry Anderson explica o fenômeno na comparação com o modernismo:

A possibilidade de outras ordens sociais era um horizonte essencial do modernismo. Uma vez desaparecido esse horizonte, surge em seu lugar algo como o pós-modernismo. Este é o momento não declarado da verdade, na interpretação de Lyotard. Como, então, pode ser resumida a conjuntura pós-moderna? Uma comparação capsular com o modernismo poderia ser a seguinte: o pós-modernismo surgiu da combinação de uma ordem dominantemente desclassificada, uma tecnologia mediatizada e uma política sem nuances. $(1999$, p. 96$)$

No que diz respeito às utopias feministas, o período é contraditório e dos mais interessantes - há um processo de afastamento de correntes feministas norte-americanas dos programas tradicionais ligados ao socialismo e, em paralelo, ocorre uma nova ascensão do feminismo liberal. Ainda é notável que muitas das demandas históricas feministas (como a horizontalidade e o questionamento da autoridade) sejam acolhidas pelo discurso hegemônico e acabem por se tornar parte da reelaboração do novo espírito do capitalismo, o neoliberalismo assuntos tratados no Capítulo 4. Assim, muitos dos sonhos feministas acabam por ser leiloados no próprio mercado, em um fantasmagórico duplo, propondo um tipo de paridade de gênero muito diferente da sonhada por muitas gerações militantes anteriores.

Uma voz central para a presente análise a respeito das limitações sobre configurações de utopias é Fredric Jameson. O autor é um dos expoentes da crítica marxista e da interpretação da 
cultura, sendo suas obras dos anos 1980 e 1990 fundamentais para a compreensão do momento histórico atual e do que se convenciona chamar de pós-modernismo - destacam-se as obras $O$ inconsciente político (1981) e Pós-modernismo ou a lógica cultural do capitalismo tardio (1996).

Entre seus escritos, a obra de referência para este trabalho é o Archaeologies of the future: the desire called utopia and other science fictions, publicado pela editora Verso em 2005 (ainda inédito em português). A obra possui duas partes: o longo ensaio The Desire Called Utopia e, na segunda parte, uma reunião de textos publicados em revistas de 1973 a 2003 (como na Science Fiction Studies e na New Left Review), além de um texto inédito sobre Phillip K. Dick.

As teses do livro Archaeologies of the future, que giram também em torno das possibilidades de configuração de utopias na era do capitalismo tardio, possuem diálogo com outra obra importante para este trabalho, Metamorphoses of science fiction: on the poetics and history of a literary genre de Darko Suvin, crítico que foi editor da revista Science Fiction Studies e publicou alguns dos ensaios que Jameson reunirá em 2005.

Se, em 1979, a obra de Darko Suvin logra assentar análises fundadoras para o gênero da ficção científica - traçar uma genealogia do gênero, mostrar a existência de formas literárias comuns, trabalhar com a ideia de estranhamento na FC, enfim, propor uma metodologia crítica para este corpus literário -, Jameson, no século XXI, dá um passo além, pois sua proposta é refletir sobre as motivações destas formas sociais, tendo sua análise uma perspectiva histórica nas mudanças, apostando no poder latente de imaginação desta literatura. É este poder latente criativo que se elege como ponto de contato entre as obras que constituem o gênero literário.

As palavras iniciais de Jameson, em Archaeologies of the future, seriam:

A utopia sempre foi uma questão política e um destino pouco comum para uma forma literária. (JAMESON, 2005, p. xi)

Ao mesmo tempo em que afirma ser um destino pouco comum, o crítico ressalta que a questão utópica é um tema recorrente do qual poderiam partir muitas análises sobre a ficção científica produzida a partir dos anos 1960.

Considerando-se a formulação de Adorno, a forma artística como conteúdo sóciohistórico decantado, é possível refletir ainda que não se trata de mero acaso a recorrência, na produção da ficção científica, da formulação do tema utopia, ao mesmo tempo em que, 
formalmente, as produções literárias raramente atinjam seus ideais de explicitar, por fim, como este brave new world seria. A insistência do aparecimento da questão utópica nos romances resolve a aparente contradição com o seu fracasso, pois caminham ligados, em uma dialética entre o aparecimento do desejo utópico e de sua impossibilidade de configuração.

Dentro do raciocínio, segundo Fredric Jameson, a dinâmica fundamental de qualquer política utópica será estabelecida, então, na dialética entre a identidade e a diferença, na medida em que tal política tenha por objetivo imaginar um sistema radicalmente diferente do presente e às vezes, inclusive, tentar torná-lo realidade. Entretanto, o fracasso reside no fato de que mesmo nossas imaginações mais delirantes não passam de colagens de experiências que já existem, construções compostas de fragmentos do aqui e do agora (JAMESON, 2005). Assim, embora a literatura apresente uma suposta liberdade infinita para o ato criativo, este não está livre das amarras do existente e nele se limita. Há um exemplo clássico de Olaf Stapledon que demonstra essa ideia a respeito dos limites de nossa imaginação:

Quando Homero constituiu a ideia da Quimera, não fez mais do que unir, em um único animal, partes correspondentes a animais distintos: cabeça de leão, corpo de cabra e rabo de serpente. (apud JAMESON, 2005, p. xiii)

Ainda na linha argumentativa de Jameson, no plano social, isso significaria dizer que nossa imaginação é refém do modo de produção existente e refém dos passados que esse modo de produção ainda conserva. Assim, no mais otimista dos casos, a utopia pode servir ao fim negativo: fazer-nos mais conscientes do nosso aprisionamento mental e ideológico. Portanto, as melhores utopias são aquelas que mais largamente fracassam.

Dessa maneira, a ideia da crítica proposta por Jameson é centrar a análise do romance na própria representação e não estritamente no conteúdo do que é imaginado: "for the more surely a given Utopia asserts its radical difference from what currendy is, to that very degree it becomes, not" (JAMESON, 2005, p. Xv). Assim, mais do que verificar o que é dito, seria mais interessante pensar no que não é dito - ou, no caso de romances que discutam utopias, - o que não é passível de ser imaginado. De forma dialética, sem conseguir nos dizer o que não é possível imaginar, esses romances, por fim, nos devolvem a nosso próprio mundo.

É importante lembrar que a mais bela das astúcias do capitalismo é nos persuadir de que somente ele pode existir - uma colonização da imaginação tanto do agora quanto do futuro. Em 
tempos de pouca esperança de transcender o modo de produção atual, como são os atuais no capitalismo tardio, talvez não seja mais possível oferecer esquemas pré-fabricados e receitas de revoluções. Mais do que definir um rumo certo e arbitrário, o interessante é manter a ideia que a alteridade é possível e poderá existir. Como afirma Jameson no fecho do ensaio sobre a trilogia marciana de Kim Stanley Robin, a respeito da estrutura desta obra que vai mitigar gradualmente a possibilidade utópica nos livros, ao ponto de a utopia nem chegar a ser configurada:

Yet utopia as a form is not the representation of radical alternatives; it is rather simply the imperative to imagine them. (JAMESON, 2005, p. 417)

A ideia que a alteridade é possível, lida nas primeiras décadas do século XXI, época em que se vislumbra o absoluto triunfo do neoliberalismo, é premente refletir sobre os últimos setenta anos como uma construção de uma ideologia de manutenção e analisar as supostas impossibilidades de alternativas, quaisquer que sejam, em uma "incessante colonização do futuro", um quadro que quase sempre nos leva à imobilidade e aporias. Como coloca Maria Elisa Cevasco (2005):

\begin{abstract}
A nossa questão cabeluda é a de como gerar alternativas nesse solo em que não nascem mais flores, nem mesmo as amarelas do medo. E mais ainda, temos que fazer isso com um olho aqui e outro na discussão geral que nos compete testar na nossa qualidade de fratura exposta do capitalismo internacional. Tanto quanto nossos colegas de esquerda do centro, temos que lutar contra a incessante obra de colonização do futuro. Como coloca Jameson, a questão para a crítica contemporânea é deslocar a temática da modernidade pelo desejo da utopia e, para tal, necessitamos construir uma ontologia do presente que exija mais do que previsões do passado, uma arqueologia do futuro.
\end{abstract}

Dentro do tema, a impossibilidade da configuração de utopias na literatura de língua inglesa na segunda metade do século XX, os livros foram escolhidos por apresentarem tentativas de utopias feministas sem as lograr, embora as duas autoras sejam conhecidas por abraçarem em sua produção as questões candentes do momento histórico, não apenas o feminismo, mas também o pensamento ecológico e a justiça social são tônicas de seus livros. Politicamente, poderíamos situar Ursula Le Guin dentro de um discurso esquerdista libertário com viés ecologista e Margaret Atwood em discurso de liberalismo democrático. ${ }^{1}$

1 Em entrevistas, Atwood já respondeu ser uma "red tory", corrente canadense que se propõe a ser progressista liberal e que balencearia direitos individuais e coletivismo. A cor vermelha é geralmente associada ao Partido Liberal de centro. A resposta: "I'm a Red Tory. To get a fix on this category, you have to go back to the 19th century. The Tories were the ones who believed that those in power had a responsibility to the community, that money should not be the measure of all things". Disponível em: http://www.motherjones.com/media/1997/07/margaret-atwood?page=2. Acesso em: 13 de dez. 2014. 
Para se discutir a dialética entre o aparecimento do desejo utópico e a impossibilidade de sua configuração nos romances, observam-se duas instâncias de análise, mais detalhadas no Capítulo 5: a das formas literárias e a da crítica da representação.

\subsection{A forma dos romances e a força da tradição}

Em primeiro lugar, a impossibilidade da configuração da utopia materializa-se nos romances no que diz respeito à sua elaboração formal. A arquitetura formal utilizada por ambas as autoras apresenta inovações na tradição do romance, o que as situa como escritoras propositivas sobre esta forma literária no século XX e acaba por movimentar materiais de conteúdo sociocultural não consolidado em literatura antes - a própria alteração do status das mulheres no pós-guerra e suas decorrências poderia ser um exemplo de material novo, que não se amolda com facilidade às produções de tradições anteriores. Entretanto, essa movimentação de novos materiais, nos romances, não é realizada de maneira isenta de contradições.

Sobre Ursula Le Guin, é possível dizer que molda seus discursos com tais "novos materiais" com bastante sintonia com seu momento histórico: em um único livro, utiliza vários gêneros literários considerados estrangeiros em comparação às formas utilizadas no romance tradicional, incorporando discursos e temas que não poderiam ser absorvidos e debatidos de outra maneira. Em The left hand of darkness, são inseridos textos, cuja forma original não provém de tradições literárias (como relatórios antropológicos, dados técnicos sobre o calendário e o relógio em outro planeta), textos estes colocados ao lado das formas típicas do romance (como narrativas em primeira e em terceira pessoas) - ocorrendo o fenômeno que Jameson irá denominar como “descontinuidades genéricas” em Generic discontinuities in SF: Brian Aldis' starship (JAMESON, JAMESON, 2005, p. 254) para a situação em que gêneros retirados de fontes e contextos diferentes são contrapostos em uma colagem, formando o romance.

Margaret Atwood, por sua vez, inova ao utilizar uma moldura à narrativa central - o relato da Aia, que ocupa grande parte do romance, seria fruto de uma reconstituição de gravações feita por dois acadêmicos - uma forma literária em diálogo com os discursos da 
contemporaneidade, como os testemunhos orais utilizados para reconstituir violações de direitos humanos, tão em vogas nas comissões de justiça e tribunais na segunda metade do século XX.

O fenômeno interessante é que, embora queiram enfrentar os temas polêmicos de suas épocas - e o feminismo seria esta polêmica -, acabam por utilizar formas conservadoras em suas constituições. Nos dois romances, é visível a oscilação entre gêneros no plano das formas tecnicamente descontinuidades genéricas, que parecem sugerir a impossibilidade da configuração de uma forma literária que tenha um "espírito genuinamente feminista", como se a força da tradição impelisse as autoras a escolhas bastante previsíveis. Se, de um lado, os romances possuem um espírito vanguardista na forma de apresentar os debates que estão na ordem do dia, por outro, quando literariamente os instituem, usam uma mescla entre formas literárias contemporâneas e formas de literaturas bem pouco propositivas, como as da tradição de romances escritos para o público feminino.

Nos dois livros, ocorre o aproveitamento das tradições de romances escritos para mulheres, o que poderia ser resumido nas seguintes estratégias de estruturar o conteúdo: o uso do melodrama e a colocação da questão subjetiva como conflito central. Exemplificando, nada mais conservador e tradicional do que a narrativa, com certo suspense, de uma história de amor impossível seguida de morte - em lugar de Capuleto e Montecchio, apresentam-se alienígenas de planetas diferentes, que é o caso de um dos fragmentos de narrativa que se encontra no romance Le Guin. Em Margaret Atwood, a voz do relato da Aia solitária e sem outra pessoa em que possa confiar muito nos recorda as cartas da lamentosa Pamela, personagem de Richardson, voz que inaugurara um importante viés que veio a ser a tradição de romances escritos para mulheres. A tradição romanesca destinada ao público feminino parece ditar os rumos das escolhas formais das autoras em momentos centrais nos romances.

\subsection{Feminismo e resignação}

Em segundo lugar, a impossibilidade da configuração da utopia pode ser analisada na crítica da representação, ou seja, indo além do conteúdo estrito das obras. 
Fredric Jameson possui um ensaio que será central: World reduction in Le Guin, publicado em 1975 e que irá depois compor Archaeologies of the future: the desire called utopia and other science fictions (2005), no qual sugere que, em última instância, o maior tema do romance de Le Guin não seria a utopia propriamente dita e sim a nossa própria incapacidade para concebê-la. Corroborando o raciocínio, é interessante que a obra descreve um impasse na história do planeta Gethen. O enclave discute os rumos do modo de vida no planeta - devem os habitantes ingressar em uma liga intergaláctica, na qual seriam da periferia de uma espécie de neoliberalismo, manter-se em um capitalismo de estado, ou, ainda, fechar-se e permanecer no feudalismo? Em lugar de o romance avançar, esse impasse é encerrado, sem ser resolvido, junto com as páginas do livro. A religião de parte dos habitantes do planeta Gethen propõe uma solução interessante a impasses sem resposta: simplesmente, não fazer perguntas às quais não se possa responder.

Margaret Atwood, por sua vez, não chega nem a representar uma utopia - uma vez que seu romance trata diretamente de uma distopia, não há proposição sobre o que poderia ter acontecido em uma história paralela além do capitalismo. Em The handmaid's tale, aprofunda-se o atual horror da economia de guerra para cruzadas infindas e vê-se uma estratificação de classes sociais mais rígida do que a que hoje conhecemos, dentro de um capitalismo inabalável com forte presença estatal. A representação, aqui, aponta para uma limitação: não se consegue vislumbrar outra ordem social possível além do capitalismo e do patriarcado.

Dessa maneira, os romances capitulam duplamente ao tentarem configurar suas utopias feministas. Enquanto forma literária, parecem não conseguir abandonar a força da tradição da literatura destinada a mulheres, embora lá tenham um desejo vanguardista. Enquanto representação, não logram apontar o que poderia ser o imaginar além do mundo que nos é apresentado hoje e, pelo contrário, ressaltam nossa incapacidade de imaginar outras formas possíveis de organizar a sociedade.

Entretanto, uma questão maior se levanta: seria o feminismo suficiente para perfazer uma utopia? Se tivéssemos a equiparação total de gênero por toda a sociedade, estaríamos em um mundo de plena justiça?

Certamente seria um mundo bem melhor do que o que hoje conhecemos. Contudo, não se resolveria a mesma velha questão que estrutura a injustiça social no capitalismo tardio: a concentração da propriedade privada, aliada à produção irracional de mercadorias, incentivando um 
padrão de consumo cada vez mais acelerado e reorganizando a obrigatoriedade do trabalho. Inclusive, o feminismo, como força capaz de alterar sensibilidades e relações entre pessoas, acaba por estar no centro da reelaboração do neoliberalismo, como se esta alteração no status das mulheres pudesse oferecer uma liberdade e uma mudança que, por fim, não ocorre. Essa capitulação, nos romances, a despeito de não perfazer ao final suas utopias sobre a questão de gênero, acaba por sinalizar a insuficiência da questão do feminismo em postular isolado a utopia de uma nova sociedade.

Qual a contribuição, então, deste estudo? Retirar alguns véus já tecidos pela crítica anterior a estes romances e esmiuçar a interpretação de maneira a perceber suas contradições inerentes, ligadas a questões históricas e sociais que são típicas do final do século XX: a resignação ao capitalismo como única forma de sociedade possível. Ler nos romances o mundo como ele realmente se apresenta.

\subsection{Sobre o contexto no qual a pesquisa foi realizada}

Por fim, uma breve consideração sobre contexto latino-americano em que este trabalho é produzido. É importante lembrar que o surgimento dos novíssimos movimentos latino-americanos na década de 2010 caminha junto de um aumento no protagonismo de mulheres. Aponta-se aqui o surgimento de muitos grupos ativistas feministas ligados a práticas novas, organizados geralmente de maneira horizontal, sendo comum o discurso anticapitalista, mas sem se inserir em um programa político-partidário. Apresentam uma grande rapidez de aglutinação e também de desarticulação, consequências de estratégias típicas de movimentos horizontais. Não se dizem representados pelas instituições mais tradicionais; tais instituições de articulação feminista já não deteriam o monopólio da militância, da discussão e da produção de conhecimento - como "tradicionais", seriam consideradas as feministas ligadas a partidos políticos, sindicatos, aos movimentos do campo ou mesmo à academia.

Segundo considera Raul Zibechi, na entrevista Movimentos portadores de uma nova cultura política (2014), esses grupos estão em constante aprendizado do fazer política e desenvolvem culturas próprias - aqui seriam considerados os espaços de encontros na internet, militantes em periferias urbanas, novas articulações feministas do movimento negro, LGBTT, 
transexuais, ativistas que mesclam outras demandas, como direitos da natureza etc. Em comum, poderíamos dizer que nascem de um contexto urbano de gentrificação (por oposição, o campo seria colonizado pelo agronegócio e pela ideologia da produção de commodities), não se enxergam representados pelos grupos de militância tradicional e sim, clamam por dialogar como equivalentes; possuem aguda percepção sobre privilégios de classe e raça; colocam em suspeita a aquisição do conhecimento e as autoridades pensantes, por exemplo, na valorização de conhecimentos nãoocidentais e na descoberta do uso de novas tecnologias; na suas constituições, procuram formas radicalizadas de democracia ("a horizontalidade é o fator unificador dos movimentos que ganharam as ruas". CLAMESHA, 2013), embora nem sempre efetivas em suas realizações; são extremamente flexíveis e conseguem amplas aglutinações, assim como se desfazem com grande rapidez, e são anticapitalistas.

Embora a crítica econômica nem sempre esteja presente com relevo, também não é possível dizer que estejam despidos de um senso sobre a totalidade da produção capitalista (como questionamentos sobre os salários das empregadas domésticas, preço do transporte público etc.). Esses movimentos feministas rompem, por hora, a imobilidade da discussão do fazer política e colocam novas perguntas, assim como inserem novos lugares e atores nos desafios do feminismo contemporâneo em uma época de crise do capitalismo global. É bem possível que suas demandas sejam reabsorvidas em uma nova etapa do neoliberalismo, se este movimento já não estiver acontecendo no momento.

Apesar de não se fazer alusão direta a este contexto histórico, é importante que seja explicitado para se compreender a importância da reflexão sobre utopia e feminismo no Brasil de 2015, pois se assiste a um sopro de novas mobilizações de grupos de militância feminista, com outras lógicas, organizações e demandas. Que o trabalho possa ser útil para estas antigas lutas e novas práticas. 


\subsection{Dados bibliográficos resumidos sobre as autoras}

Darko Ronald Suvin, crítico que dedicou boa parte de sua produção à ficção científica e foi editor da revista Science Fiction Studies, ${ }^{2}$ comenta que poderia designar certo grupo de escritores com romances publicados por volta do ano de 1969, aqui inserida Ursula Le Guin de LHD, como New Left' SF writers (1970; 1975), exemplificando também com The lagged orbit de John Brunner, Bug jack barron de Norman Richard Spinrad, assim como com a produção de Roger Joseph Zelazny e Joanna Russ - para Suvin, Ursula Le Guin é a mais significativa escritora deste grupo (SUVIN, 1975). A alcunha se refere mais à sensibilidade e à visão de mundo destes autores do que à filiação política propriamente dita. $\mathrm{O}$ denominador comum destes escritores seria a oposição radical à crença na ideologia do individualismo e a maneira pela qual lidam com uma sociedade neocapitalista, ${ }^{3}$ em que as escalas são massivas: nos descontentamentos, nas comunicações e nos colapsos.

Retomando a cronologia desenvolvida por Ian Watson (1975), os principais livros de Le Guin, na ordem de sucessão do denominado "ciclo hainiano", seriam: The dispossessed (publicado em 1974), que se passa entre o planeta-mãe Urras e sua lua árida Anarres, contrastando sistemas sociais: no planeta, há formas comunitárias de organização social e, na lua, um sistema análogo ao capitalista, figuras que discutem as polaridades configuradas na Guerra Fria; ${ }^{4}$ The word for world is forest (1976), sobre a colônia Novo Taiti fundada no planeta Athshe; depois se seguem três romances, que foram algumas vezes publicados em um único volume: Rocannon's world (1966),

\footnotetext{
${ }^{2}$ Suvin foi editor do periódico nos anos de 1973 a 1980. A revista, de grande valia aos estudos sobre ficção científica, pode ser encontrada site http://www.depauw.edu/site/sfs, mantido pela Universidade DePauw em Greencastle, Pensilvânia.

${ }^{3} \mathrm{O}$ termo neocapitalismo foi utilizado também por outros teóricos para designar as transformações do capitalismo após 1945. Por exemplo, Ernest Mandel, antes de publicar $O$ capitalismo tardio, também utilizava o termo, como na obra Ensayos sobre el neocapitalismo (1971). Mandel passa a utilizar "capitalismo tardio" por entender que "neocapitalismo" poderia caracterizar "tanto uma continuidade como uma descontinuidade em relação ao período anterior", mesmo que ache o termo "capitalismo tardio" limitado, por ser apenas uma caracterização cronológica e não sintética". Cf. SILVA (2012, p.18).

${ }^{4}$ Em The Dispossessed, Le Guin constrói no texto várias ambiguidades e contradições: é interessante apontar que, em Urras, aparentemente não há benefícios especiais a classes superiores ou mesmo ainda se sugere que haja a supressão da categoria classe social (a meta dos colonos originários do planeta). Entretanto, pouco a pouco, são deslindadas formas de controle e de poder diferenciados a certos nichos, como cientistas, e mostradas formas de exploração, como o trabalho em transportadores pelos desertos, o sorteio viciado de postos de trabalho e outros indícios de estratificação social. Ainda permeiam a vida em Urras o autoritarismo, a burocracia, o impedimento à criação artística (por exemplo, o músico que gostaria de compor outras melodias) e a impossibilidade de vida conjugal. Na lua árida denominada Anarres, é clara a segmentação em classes sociais e a estratificação, assim como a questão central do poder e desprezo às classes mais baixas, muito semelhante ao que conhecemos. Dessa maneira, Le Guin deixa aberta muitas possibilidades críticas, sendo uma das obras mais discutidas de sua produção.
} 
Planet of exile (1967) e City of illusions (1967). ${ }^{5} \mathrm{Na}$ sequência cronológica hainiana, teríamos, então, The left hand of darkness (1969). Dentro da série, existem ainda contos esparsos, como os resumidos no tomo Four ways to forgiveness (1995), e o livro The telling (2000). Ursula Le Guin publicou, em paralelo, a série Earthsea, constituída por seis livros, lançados entre 1968 e 2001, que o mercado editorial destina ao público infantojuvenil, e alguns outros contos e romances.

Margaret Eleanor Atwood é uma escritora canadense nascida em 1939, Ottawa. Possui uma obra profícua, ${ }^{6}$ que se inicia em 1961. Publicou vários romances, livros de poesia (uma coletânea representativa seria Selected poems 1966-1984 [1990]), livros de contos (com destaque para Wilderness tips [1991] e Good bones [1992]), livros infantis (Wandering Wenda and widow Wallop's wunderground washery [2011]), apanhados críticos (por exemplo, sobre literatura canadense, Survival: a thematic guide to canadian literature [1972], e sobre criação literária, Negotiating with the dead: a writer on writing [2002]), assim como peças de teatro, roteiros para rádio e televisão.

No que se refere a seus romances, poderíamos traçar uma divisão que a própria autora sugeriu (INGERSOLL, 2006, p. 219): um primeiro trio, que trata de relações interpessoais dramáticas entre mulheres e homens - The edible woman (1969), Surfacing (1972) e Lady Oracle (1976) - e um segundo trio, em que a temática central teria um aprofundamento na representação do feminino (With women and women), onde se situa o objeto atual de estudo: The handmaid's Tale (1985); Cat's eye (1988) e The robber bride (1993). A produção durante os anos 80 e 90, de certa maneira, mantém esses eixos temáticos, que poderíamos dizer que tratam de relações interpessoais; assim teríamos, cronologicamente, as publicações de Life before man (1979), Bodily harm (1981), Alias grace (1996) e The blind assassin (2000) - este último obteve um largo alcance editorial. No século XXI, há uma ruptura temática maior na produção e a autora incursiona pelo gênero da ficção científica com três livros: Oryx and Crake (2003), em que duas distopias e uma utopia encontram-se imbricadas (cf. JAMESON, 2009), cuja narrativa paralela se desenrola em The year of the flood (2009) e depois em MaddAddam (2013).

Atwood trabalha com muita recorrência sobre as questões da condição social da mulher e de sua representação, dentro da circunscrição do universo feminino norte-americano e europeu de

\footnotetext{
${ }^{5}$ Os livros Three Hainish Novels (1978, Ed. Nelson Doubleday) e Worlds of Exile and Illusion (1996, Orb) trazem os romances Rocannon's World, Planet of Exile and City of Illusions em um único volume.

${ }^{6} \mathrm{O}$ catálogo com a bibliografia completa pode ser encontrado em seu site: http://margaretatwood.ca.
} 
classe média, questões que irão encontrar eco também em alguns outros círculos sociais. Esses temas são bem explorados em romances como The edible woman, Lady Oracle, The handmaid's tale e Cat's eye. Um dos temas em The edible woman é a problemática sobre a identidade que envolve a construção da mulher ter ainda um vínculo necessário com o rito do casamento e as configurações sociais sobre a divisão de papéis de gênero. Em Lady Oracle e Cat's eye, aparecem também o questionamento da educação sentimental destinada às mulheres, a configuração do corpo dentro de regras estéticas rígidas, as maneiras de ocupação do espaço privado e a construção identitária do que seria "mulher". Em The handmaid's tale, os temas citados aparecem com bastante ênfase, incluindo o acesso das mulheres aos poderes político e econômico.

Dessa forma, pode-se dizer que, nos anos de 1970 até início dos 1990, Margaret Atwood trata de discutir o papel das mulheres e sua educação sentimental, dentro de uma moldura interessante de transição histórica no que se diz respeito às mulheres brancas de classe média (principalmente marcada pela consolidação de sua entrada maciça destas no mercado de trabalho, sem vislumbrarem, contudo, a tão prometida equiparação aos homens), quando se assiste a muitas ações de resistência ao papel subalterno que lhes seria destinado, ao mesmo tempo em que não se consegue enxergar uma superação possível da condição que não seja a destruição dos próprios privilégios. 


\section{Capítulo 2 - The left Hand of Darkness: utopia e imaginação}

\subsection{0 ciclo hainiano: anticapitalismo e pacifismo}

A produção de Ursula Le Guin nos anos de 1960 e 1970 é considerada pela crítica como engajada à agenda de movimentos anticapitalistas, tratando de temas como o neocolonialismo, ecologia, feminismo e formas possíveis de organização política quanto a reorganização do modelo de produção - um de seus críticos que faz esta consideração é Darko Suvin, que pode ser lida em Parables of De-Alienation: Le Guin's Widdershins Dance (SUVIN, 1975). A autora, nestes anos, está inserida no auge dos movimentos da contracultura e está atenta a examinar propostas sociais que procuram novas formas de organização em sociedade - interessa-se pelas posturas contrárias ao consumo exacerbado, pela busca por novas formas de interação entre pessoas e por vivências comunitárias radicalmente contrárias à guerra e ao autoritarismo.

Cada um dos livros do ciclo hainiano de Le Guin, romances que possuem como eixo de ligação os humanoides hainianos, retrata o cotidiano de determinado planeta ou de um sistema planetário, tendo em vista as condições ambientais, o modo de vida de seus habitantes e o modo de produção adotado. No centro das narrativas de todo o ciclo, situa-se o Ekumen, uma liga supraplanetária, uma espécie de Organização das Nações Unidas ou Organização Mundial do Comércio fortalecida, politicamente liderada pelo planeta Hain. Os hainianos são colonizadores de outros mundos e detentores de alta tecnologia, como o ansível, meio de comunicação entre planetas. The left hand of darkness passa-se no planeta Inverno.

Um dos eixos temáticos do ciclo hainiano gira em torno de ocorrências típicas do desenvolvimento do capitalismo após a Segunda Guerra: a exploração econômica entre planetas e sistemas planetários de desenvolvimento desigual, os resultados do colonialismo e de outras formas de dominação econômica perpetuados por uso de tecnologias tidas como superiores (como o ansível para se comunicar e formas mais rápidas de viagens espaciais), a pressão para a integração de 
economias mais frágeis a pactos econômicos para circulação de mercadorias, que gera efeitos profundos nas populações nativas de planetas menos "desenvolvidos".

Aqui, a ficção científica atua como uma maneira de extrapolar hipóteses imaginativas criadas a partir de fatos reais. As ocorrências de catástrofes humanitárias e ambientais no pós-guerra possuem uma dimensão de tal enormidade e irracionalidade, que dependem de um dispositivo mental - que seria a representação de tais ocorrências na literatura e no cinema - para que possam ser apreendidas pelas pessoas, para que se consiga absorver essas informações. Por exemplo, se observarmos a atual exploração de minérios - embora se diga que hoje a tecnologia mineradora seja "a mais avançada", em pleno século XXI ela segue dizimando populações inteiras, extinguindo ecossistemas, intoxicando solo e ar, perpetuando a concentração de terra e de poder nas mesmas mãos que os detinham no século XIX. Os Estados modernos, no pós-guerra, seguem corporificando ainda tanto a parteira quanto o componente imanente do sistema produtor de mercadorias, "recipientes institucionais da riqueza nacional abstrata, para cuja acumulação sem sentindo ele tem de reunir as necessidades e os impulsos humanos numa única vontade global exteriormente imposta" (KURZ, 2004, p. 40). O dinheiro, que somente pode existir no contexto do mercado e da circulação de mercadorias, é a existência encarnada da riqueza abstrata, deste trabalho morto que se multiplica (KURZ, 2004, p. 68). Le Guin, com sua percepção sensível às causas humanas e ambientais, transpõe essas realidades e lugares-comuns de regiões na África, América Latina e Ásia para hipóteses imaginativas situadas em planetas sob o domínio hainiano.

Esta época, denominada capitalismo tardio, expressão difundida por Ernest Mandel (termo que preserva, na semântica, uma continuidade do período anterior, assim como o declínio do sistema), tem como marcas tanto a expansão do processo de acumulação quanto o agudização das contradições inerentes ao modo de produção capitalista (ANDERSON, 1989, p. 140). Fredric Jameson, quando discute o uso do termo, em sua introdução da obra Pós-modernismo - a lógica do capitalismo tardio (2006, p. 89), descreve o cenário da seguinte maneira:

Além das empresas transnacionais (...), suas características incluem a nova divisão internacional do trabalho, a nova dinâmica vertiginosa de transações bancárias internacionais e das bolsas de valores (incluindo as imensas dívidas do Segundo e do Terceiro Mundo), novas formas de inter-relacionamento das mídias (incluídos os sistemas de transportes como a conteinerização), computadores e automação, a fuga da produção para áreas desenvolvidas do Terceiro Mundo, ao lado das consequências sociais mais conhecidas, incluindo a crise do trabalho tradicional, a emergência dos yuppies e a aristocratização em escala agora global. 
Entretanto, é preciso ressaltar que, no campo da cultura, as transformações sociais e psicológicas ocorrem apenas nos anos 60, "que varreram do mapa tantas tradições no nível das mentalités". (JAMESON, 2006a, p. 23-24) Somente após a vivência do pós-guerra, marcada pela falta de bens de consumo e de peças de reposição, os quais, por sua vez, foram repostos por novas tecnologias, formas de comunicação e produtos, é que ocorrerá uma alteração mais profunda na configuração cultural (inclusive, Jameson aponta que alguns experimentos modernistas vistos como “predecessores” dessa mudança não o são propriamente). Dessa maneira, ainda segundo Jameson, a cristalização do sistema econômico do capitalismo tardio, com o desenvolvimento das formas culturais do pós-modernismo, dar-se-ia somente "com o grande choque da crise de 1973 (a crise do petróleo, o fim do padrão-ouro internacional, o fim, para todos os efeitos, das 'guerras de libertação nacional' e o começo do fim do comunismo tradicional)" (JAMESON, 2006a, p. 24). Assim, é no período que antecede essa cristalização da "nova e estranha paisagem", a que se refere Jameson quando comenta a lógica cultural do pós-modernismo, que Ursula Le Guin situa seus planetas e tece suas investigações imaginativas.

Dentro dos romances da série hainiana, há a sugestão de que, para os colonizadores de mundos, os planetas que ainda não foram tocados pela alta tecnologia e que não se inserem em ligas planetárias marcadas "não possuiriam história" (uma apropriação distorcida pelos hainianos do conceito hegeliano de História) - em LHD, esta ideia não aparece com relevo, pois é exatamente a chegada do colonizador que gira a roda da História em Inverno.

É interessante perceber como assuntos que não caberiam na forma do romance tradicional são bem acomodados nas obras de Le Guin do ciclo hainiano, sendo a utilização da forma literária com alternância de vários gêneros a responsável por conseguir acomodar matérias distintas, a princípio de caráter "não-literário": 7 informações etnográficas, análises socioculturais, políticas, econômicas, todas com grande relevância para esta época da produção da ficção científica, dado que, entre outras preocupações, os New Left' SF writers procuram imaginar "como seriam as relações humanas sem a mercantilização, como seria um mundo sem publicidade, como as

\footnotetext{
${ }^{7}$ Empresta-se aqui uma noção dos estudos de Análise do Discurso: "texto não-literário" seria um texto em que não há preponderância da função poética, sendo essa última compreendida resumidamente como o emprego de procedimentos no plano de expressão em combinação com o plano de conteúdo (para mais detalhes, BARROS, Diana Luz Pessoa, A Comunicação Humana, in Introdução à Linguística I, São Paulo: Contexto, 2004, p. 39). Mesmo dentro dessa concepção teórica, o uso de tais textos, como um "manual para pilotar aeronaves" dentro de um livro de ficção científica, poderia adquirir o caráter de uso "literário", pois estariam dentro de uma moldura metafórica maior.
} 
narrativas moldariam a vida das pessoas sem os corpos estranhos dos negócios e do lucro" (JAMESON, 1997, p. 84).

\subsection{Três momentos da crítica: de utopia política aos estudos de gênero}

Pode-se analisar a recepção crítica de LHD segmentada em três períodos cronológicos. Essa maneira de divisão em três momentos é bastante útil para se pensar um movimento histórico por detrás da crítica à obra, mostrando emergências de questões que pareciam adormecidas de início e também aponta o arrefecimento de questões que, no início, pareciam essenciais, embora a divisão arbitrária não dê conta do número de trabalhos críticos e nem de sua complexidade, como se pode esperar. De qualquer forma, a proposta é observar, em linhas gerais, um primeiro momento, durante os anos de 1970, em que a obra recebe análises interessadas nos temas da colonização, das formas literárias e das utopias políticas. Em um segundo momento, o livro seria lido dentro das chaves feministas e de questões de gênero, o que se daria com a década de 1980 a 2000. No terceiro momento, a partir dos anos 2000, em que este próprio trabalho se enquadra, se proporiam leituras que tentam organizar um diálogo com as preocupações críticas anteriores - este diálogo foi nem sempre bem sucedido ou claramente estruturado, pois as linhas críticas atuais apresentem um grau maior de independência metodológica e diferenças ideológicas, sendo muito mais difíceis de resumir e de se categorizar os temas e objetivos das análises críticas mais contemporâneas, até pela menor diferença de tempo transcorrido que impede uma mirada mais afastada e objetiva.

Neste primeiro momento, logo após a publicação da obra, além do já comentado ensaio de Fredric Jameson World-reduction in Le Guin: the emergence of utopian narrative de 1975, despontam alguns trabalhos iniciais para se pensar a obra de Le Guin. Muitos destes textos encontram-se nas revistas especializadas, algumas bastante engajadas com temas políticos, o que é evidenciado em seus títulos: Anarchist studies, Extrapolation: a Journal of science fiction and fantasy, Science fiction studies, The magazine of fantasy and science fiction e Women's studies international forum. Ian Watson (1975) fez um esforço, muito citado na crítica que o sucede, em realizar uma cronologia, citada anteriormente, dos romances do ciclo hainiano (aquelas obras em que figuram a atuação do planeta Hain), no sentido de organizar a ordem interna dos livros, conforme as tentativas de colonização do Ekumen. Também compreendendo o ciclo hainiano em 
um todo maior, Barbour (1974), em Wholeness and balance in the hainish novels of Ursula K. Le Guin, fez a proposição de ler os romances como interligados no que se concerne a enredo e temas, apontando uma moldura maior em que a autora trabalha, ressaltando alguns valores que são repetidos em LHD, como o encontro de culturas e a possibilidade de uma coexistência pacífica, uma forma de contato fora do marco da colonização e do domínio:

For Le Guin's artistic vision, her deep understanding of the real meaning of culture, has always been ambiguous, multiplex, subtle, and dualistic/holistic in the sense that it has always recognized the cultural relativity of "truth." Always, in her work, the representatives of different cultures meet, interact, and, in the cases that count, learn of each other (often through love) that they are equally human, part of the great brotherhood of "man". (BARBOUR, 1974).

A estes críticos dos anos de 1970 concede-se um papel importante que é o de serem a primeira geração que fará colocações sobre o romance. Cada qual apresenta um olhar independente, fresco, sem ser necessária a reiteração da crítica anterior. Assim, dentro do tema maior que são as análises sobre utopias políticas, cada um consegue organizar aspectos mais específicos sobre a obra. São exemplos disso Martin Bickman (1977), que analisa a maneira de construção formal que Le Guin utiliza em LHD, contrastando a forma dos romances com a de outros escritores do período como Phillip K. Dick e Stanislaw Lem - a forma de LHD já traria incorporada os movimentos de “tese-antítese-síntese” obtida pela alternância e interpenetração de fatos, mitos, de texto literal e de texto figurativo; e John Huntington (1975), que trabalha o romance dentro da proposta de analisar o que seria considerado de âmbito público e privado:

LHD attains a more difficult balance of public and private imperatives, for this later novel does not offer the earlier one's clear-cut public justification for private sacrifice. The two political systems of Gethen, Karhide's feudal one and Orgoreyn's totalitarian-collectivist one, are both corrupt and destructive of individual values, and if the feudal is favored over the totalitarian it is only because it is the more flexible and the more easily influenced of the two; its inefficiency is its virtue. We find no neat distinction available between the good and bad political systems; Genly Ai faces no absolute enemy against whom any act is permitted or sacrifice justified. Also, Ai's goal of persuading Gethen to join the Ekumen lacks the element of urgent crisis that sanctions Rocannon's public acts. In fact, it is important to Ai's mission that there be no public compulsion that would make Gethen's decision to join seem anything less than completely voluntary.

A guinada nas análises de LHD, que depois será aprofundada dentro dos que se convenciona chamar de gender studies, inicia-se no final dos anos de 1970 e será um dos grandes tópicos nos anos de 1980 para os estudos sobre o romance. Aqui se pode considerar que a crítica 
traça um segundo movimento, no qual um dos pontos de partida para a leitura do romance é, necessariamente, o feminismo.

Um dos textos precursores da questão é o de Ellen Morgan (1977), com o texto The feminist novel of androgynous fantasy. De saída, considera o romance de Le Guin feminista, o que não era assinalado de maneira tão clara pela crítica anterior. A estudiosa pergunta-se qual a necessidade de se utilizar um aparato de ordem não-realista, no caso, a ficção científica, para se conseguir representar o que seria a androginia - em outras palavras, qual o motivo do realismo não dar conta de discutir uma nova/outra femininity? Sublinha a importância da fantasia neste tipo de literatura:

Fantasy remains the primary vehicle for the depiction of women who successfully breach the barriers of sexual caste in order to achieve authenticity. So fantasies are an important kind of feminist literature. (MORGAN, 1977, p. 40)

Morgan, em seu texto, analisa ainda o clássico Orlando de Virginia Woolf (1928), In transit: an heroicycle novel de Brigid Brophy (1969) e The female man de Joanna Russ (1971) e outras obras que considera feministas, propondo não apenas uma questão teórica, mas também uma forma de aglutinar o estudo de romances que, até então, pareciam figurar em tradições distintas como na alta literatura, na ficção científica, etc. Entre outros como LEFANU e MURPHY (1989), o crítico Peter Fitting (1985) dará continuidade a esta lógica de entender, de saída LHD como romance feminista, em uma análise que seleciona diversas obras dentro deste guarda-chuva maior desde obras pertencentes à FC, como Triton de Samuel Delany (1976), Woman on the edge of time de Marge Piercy (1976) e o citado The female man de Joanna Russ (1975), até romances que pertenceriam ao gênero fantástico como Motherlines de Suzy McKee Charnas (1978), The wanderground de Sally Gearhart (1978) e Ecotopia de Ernest Callenbach (1975). A proposta do crítico é apontar como o ideal feminista consegue retratar a vida cotidiana e nos oferecer algumas esperanças de emancipação:

One of the most significant features of the revival of utopian themes in US popular fiction has been the impact of feminism. Through an examination of seven novels, I will argue both for the importance of feminist ideals in reshaping utopian writing, especially in its portrayal of everyday life in worlds without the present hierarchies and gender system, and for the effectiveness of such writing in awakening and giving shape and direction to existing emancipatory hopes.

Observa-se, neste período, uma tentativa de se propor outra metodologia de análise literária com base nas demandas políticas feministas ou ainda de unificação de parâmetros críticos 
para obras que, a princípio, filiariam-se a tradições distintas - alta cultura, ficção científica e fantasia. Este "incômodo" na diferença de linguagens e de gêneros será mais bem trabalhado, anos depois, por Jameson com o suporte de Raymond Williams, na compreensão de que haveria uma provável superação da dicotomia tradicional entre cultura de massa e alta cultura no pósmodernismo.

No paralelo com esta linha crítica que considera LHD um romance feminista $a$ priori, nos anos de 1980 e 1990, a crítica apresenta um novo movimento: surgem várias contestações ao "feminismo" representado no romance (PEEL, 1997), o que parece ter forçado a autora a dar explicações sobre a própria obra (a série de textos Is gender necessary?), considerações que podem ser lidas no item 4.5 do presente trabalho - os escritores Stanislaw Lem e Joanna Russ, além de outros críticos, trarão uma série de questionamentos sobre a suposta ambissexualidade dos habitantes do planeta Gethen, que poderia mascarar uma insuficiência na imaginação utópica sobre o que poderia ser uma liberdade absoluta causada pela ausência de diferença de gênero.

Em estudos mais recentes, a exemplo do trabalho de Brian Attebery e Patricia Melzer, procuram-se resumir estas contradições não no sentido de desatar um suposto nó e sim manter as tensões que a respeito das questões de gênero. Em Alien constructions, Melzer (2006, p. 222) procura mostrar como, em obras posteriores, muitas romancistas darão conta de ir além da mera androginia espelhada em um modelo masculino, como considera LHD de Le Guin, embora tragam outras contradições. No capítulo Androgyny as difference, Brian Attebery resume uma série de discussões a respeito do que seria a androginia ou a ambissexualidade dos habitantes do planeta Gethen à luz de várias críticas específicas sobre o tema no seguinte parágrafo:

So "The left hand of darkness" has become part of the feminist canon - although within that canon, unfortunately, it is sometimes reduced to a few memorable quotations about gender, with the more obviously science fictional elements discreetly ignored. Along with attention, futhermore, has come controversy. Two objections have been raised against the book: first, that it does not go far enough in its depiction of androgyny; and, second, that androgyny itself is, rather than a liberating vision, a betrayal of feminist aims. (ATTEBERY, 2002, p. 131).

Em resumo, é possível dizer que, em um primeiro momento, as análises se centravam em compreender LHD dentro do ciclo hainiano da autora e tendo por linhas de análises mestras o questionamento de forma do romance e de uma configuração de uma utopia política. Em um segundo momento, a fortuna crítica encaminhou-se para centralizar suas preocupações sobre o 
ideário feminista trazido pelo romance, procurando um diálogo de LHD com obras do alto modernismo, em especial Orlando, na afirmação de uma suposta construção de um cânone de uma literatura considerada feminista. Este segundo momento encerra-se com uma aporia: justamente o aprofundamento do estudo sobre a representação da ausência de gênero no romance aponta suas insuficiências. O terceiro momento da crítica, que assistimos nos dias de hoje, procura entender estas contradições dentro do horizonte histórico e mostrar que seguem existentes em obras produzidas no século XXI. Neste trabalho, tenta-se recuperar estas ideias, sem esquecer a contribuição de Jameson no estudo da obra a respeito da limitação à configuração da utopia política que o romance encerra, preocupação que parece bastante esquecida nos estudos críticos contemporâneos.

No mais, algumas observações sobre as especificidades das fontes críticas sobre FC em âmbito de língua inglesa: sendo a ficção científica um gênero literário de valorização bastante recente dentro da universidade (aqui se assinala os esforços de Jameson, Suvin e outros), há uma quantidade significativa de textos elaborados por pessoas interessadas, mas não necessariamente com propósitos acadêmicos ou uma metodologia crítica clara: são textos de outros escritores, leitores engajados, fãs e curiosos. Estes textos foram relevantes, historicamente, para a atual construção crítica que se forma em torno do gênero. Ainda se fazem dignos de menção alguns blogueiros que se dedicam aos temas da FC, compartilhando bibliografias e listas de leituras, muitas bem mais completas do as que constam em revisões críticas de cunho acadêmico (como WEYANT, 2014, e TILLACK, 2014). No caso do presente trabalho, foram levados em conta quando se mostraram pertinentes. Por fim, percebe-se uma recorrência na utilização do compartilhamento com direitos autorais flexibilizados ou com maior acessibilidade do que estudos críticos sobre outros corpora literários, sendo possível dizer que os estudos em torno da FC apresentam uma sensibilidade maior ao tema da propriedade intelectual e à necessidade da organização de informações - cita-se, por exemplo, os arquivos da DePauw University, o trabalho da The Free Library, da Internet Science Fiction Database e da OpenLibrary. Essa generosidade ao acesso é um bonito estímulo para os críticos do futuro.

Por fim, a respeito da repercussão crítica da produção de Ursula Le Guin no Brasil, é possível afirmar que é bastante restrita, apesar do relativo sucesso na distribuição de suas obras no 
território brasileiro e do grande número de leitores. Até o momento, não se encontraram registros de estudos feitos nos principais bancos de teses, segundo busca feita no Portal da CAPES em $2014 .^{8}$

\subsection{0 planeta Gethen/Inverno}

Examinando a obra do período de produção da autora ao qual se convencionou denominar ciclo hainiano (obras em que figuram o planeta Hain), The left hand of darkness ocupa uma posição privilegiada, pois investiga a maneira pela qual é feita a integração de um planeta ao Ekumen. O planeta em questão, Inverno (denominado Gethen pelos próprios habitantes), é inicialmente apenas observado pelos hainianos. Após esta etapa, recebe uma intervenção pontual: a ida do Primeiro Móvel, um único homem, de maneira a não gerar alarmes ou respostas violentas pelos povos recebedores do cavalo troiano. A missão do Primeiro Móvel é sensibilizar os governos locais e fomentar o processo de "amadurecimento político" do planeta para que um dia seus governantes se decidam, então, pela integração ao Espaço do Ekumen.

Há sempre uma crítica subjacente ao discurso liberal e aparentemente democrático do Ekumen ("o Ekumen não governa, ele coordena" [LE GUIN, 2005, p. 25]), crítica presente até na própria escolha irônica do título da liga: Ekumen, que traz a semântica de "ecumênico", "universal", “conciliador", "pacífico", "que reúne em comunhão" (a passagem é considerada ecumênica no contexto da Bíblia, nas palavras do apóstolo Paulo, "o que nos une é maior do que o que nos separa").

$\mathrm{Na}$ obra, estabelece-se uma insistência nesta "persuasão" aos planetas ainda não ingressantes: se o Primeiro Móvel falhar, serão enviados outro e mais outro. Também é deixado claro o tamanho ameaçador do Espaço do Ekumen, composto por 83 planetas habitáveis e 3.000 nações. Por fim, uma vez tendo ingressado, o planeta não está livre de sanções ekumênicas, inclusive militares:

(...) o Ekumen interfere como mediador, tentando fazer um ajuste, um acordo, uma escolha legal ou ética. Agora, se o Ekumen, como experiência no superorgânico, vier a fracassar, terá que se tornar uma força de paz, desenvolver uma polícia e assim por diante. (LE GUIN, 2005, p. 135)

\footnotetext{
${ }^{8}$ O portal da CAPES apresenta a limitação de indexar obras somente a partir dos anos 2000.
} 
O contexto histórico em que o livro foi produzido é útil para se interpretar a figura do Ekumen, época em que a liberalização prevista por mecanismos internacionais no pós-guerra começava a ter efeitos plenos. Lembre-se, por exemplo, do GATT - Acordo Geral sobre Tarifas e Comércio, estabelecido em 1947 e implantado de forma progressiva: assiste-se ao estabelecimento de transações comerciais dimensionadas agora para escalas globais, com lucros inegáveis aos conglomerados empresariais situados em países de maior desenvolvimento; à flexibilização de antigas barreiras aduaneiras, antes um importante instrumento de proteção de indústrias nacionais; às negociações agressivas em fóruns multilaterais, de modo que países com menor desenvolvimento relativo sejam pressionados a assumir seus papéis subalternos no livre comércio, enfim, assiste-se à construção da hegemonia político-econômica dos Estados Unidos e suas indústrias na segunda metade do século XX, atores que fazem as vezes dos hainianos de Le Guin.

Argaven Harge, o rei da nação Karhide em Inverno, tem um diálogo esclarecedor com o Primeiro Móvel sobre o motivo principal da missão ekumênica: ampliar o lucro material. No diálogo, inicialmente, o Primeiro Móvel defende-se dos ataques do rei, explicando sua missão:

- Não fiz segredo disso, senhor. O Ekumen quer uma aliança com as nações de Gethen.

- Para quê?

- Lucro material. Expansão do conhecimento. Aumento da complexidade e intensidade no campo da vida inteligente. Enriquecimento da harmonia e da glória maior de Deus. Curiosidade. Aventura. Prazer. (LE GUIN, 2005, p. 41)

Mais à frente, o Primeiro Móvel fornece mais detalhes sobre a sua missão e os supostos benefícios para a nação Karhide no planeta Inverno, com tom de representante para assinar acordo de livre comércio:

O comércio, entretanto, vale a pena. De ideias e técnicas, comunicadas via ansível; de mercadorias e artefatos, enviadas por naves, tripuladas ou não. Embaixadores, estudiosos e mercadores, alguns deles poderiam vir para cá; alguns dos seus poderiam visitar outros planetas. O Ekumen não é um reino, mas sim um coordenador, uma câmara de compensação de comércio e conhecimento. (LE GUIN, 2005, p. 41-42)

O relatório do Primeiro Móvel, Genly Ali, que desempenha "o trabalho de um homem só", cuja missão é anunciar os interesses do Ekumen e explicar como serão os novos tempos, possui um grande valor na obra. Dividido em vários capítulos, os quais são entrecortados por outros 
assuntos, o relatório assume uma importância formal na estrutura do romance, dado que condensa muitos dos trechos em que ocorre a ação propriamente dita. Há um sentido formal para que a narrativa caminhe quando Genly Ali narra, dado o fato de que sua missão irá alterar o rumo da vida dos habitantes de Gethen, que, até então, parecia congelada e resumida ao planeta de gelo:

Os Estáveis do Ekumen são homens muito pacientes, senhor. Vão esperar cem, quinhentos anos, até que Karhide e o restante de Gethen deliberem e decidam se desejam unir-se ao resto da humanidade. (LE GUIN, 2005, p. 41)

Ironicamente, não há outra escolha possível aos que são escolhidos para a intervenção ekumênica. O "toque ekumênico" feito pelo Primeiro Móvel girará a roda da História em Inverno: no planeta, há o confronto entre duas nações locais, eternamente rivais, embora a guerra não seja conhecida em Inverno (“[...] não falei em guerra por uma boa razão: não existe palavra para isso em karhideano" [LE GUIN, 2005, p. 41]). Em Inverno, há uma nação medieval, Karhide, que possui um rei e uma rede intrincada de conselheiros políticos ("Karhide não é uma nação, mas uma briga de família") ${ }^{9}$, e uma nação burocrática, Orgoreyn, com polícia secreta e conselho de comércio aberto ("O Sarf tem um controle mais completo sobre as comunicações do que eu sabia ou pensava ser possível” [LE GUIN, 2005, p. 41]). Darko Suvin sugere que, embora Orgoreyn possa parecer uma justaposição da União Soviética com os Estados Unidos, sua configuração é mais complexa e sairia da simplicidade do "eles contra nós” típica da Guerra Fria (SUVIN, 1970).

Sem parecer paradoxal, o planeta Gethen/Inverno apresenta reis, camponeses e burocratas. Ao mesmo tempo, possui uma tecnologia avançada sem ser fruto do capitalismo. Há um confronto dormente em Inverno, que a vinda do Enviado acordará. Contudo, nem o início nem o desfecho deste confronto são descritos no livro, a narrativa é suspensa antes, sem nos contar o futuro de Inverno - LHD apenas posiciona peças no tabuleiro para que o leitor possa imaginar saídas possíveis para essas nações.

Além da ausência de guerra ou de revolução social, um dos elementos centrais no livro é o fato de os habitantes de Gethen/Inverno serem ambissexuais: os gethenianos são andróginos na maior parte do tempo. Quando entram no cio, o kemmer, adquirem características femininas ou masculinas, podendo, assim, qualquer habitante gerar no ventre um filho - uma frase que ficou famosa com a publicação do livro foi "the King was pregnant”. Esta característica é esmiuçada de

9 “Sarf”seria a polícia secreta em Orgoreyn (LE GUIN, 2005, p. 149). 
diversas maneiras no livro e foi a que gerou maiores comentários críticos à época de seu lançamento.

A hipótese para essa característica dos gethenianos é que seria fruto de manipulações genéticas dos hainianos, nas palavras da investigadora Ong Tot Oppong:

Dia 81. Parece provável que eles tenham sido uma experiência. A ideia é desagradável. Mas, agora que há evidências de que a Colônia Terráquea foi uma experiência, com a implantação de um grupo Hainiano Normal num planeta com seus próprios proto-hominídeos autóctones, a possibilidade não pode ser ignorada. (...) Acidente, talvez; seleção natural, dificilmente. Sua ambissexualidade tem pouco ou nenhum valor adaptativo. (LE GUIN, 2005, p. 91)

Aqui, novamente, há o contexto que emerge - à época da publicação do romance, já se vislumbrava a possibilidade de isolar genes humanos ${ }^{10} \mathrm{e}$, por ocorrência da Guerra do Vietnã, especulava-se sobre a utilização de armas biológicas e realização de experimentos em seres humanos no front, considerando que os Estados Unidos faziam uso de armas químicas proscritas pela Convenção de Genebra na Guerra do Vietnã, como o Napalm e outros agentes químicos tidos como "ilegais". Frise-se: os mesmos Estados Unidos que, em 1947, conduziram o "Processo dos Médicos”, o primeiro julgamento do Tribunal de Nuremberg (Estados Unidos da América v. Karl Brandt, et al.), para condenação dos médicos nazistas acusados de realizar experimentos em seres humanos. A noção de que o corpo do "inimigo" ou o corpo do "subjugado" poderia ser reduzido à mera matéria-prima em processo de produção de mercadorias (extrapolada pelos nazistas com sua racionalidade macabra de utilizar até cartões perfurados para organizar a administração - a famosa acusação sobre a colaboração da empresa IBM ao Segundo Reich) está presente no romance com a hipótese da investigadora Ong Tot Oppong a respeito dos limites pouco éticos dos hainianos quando realizaram experimentos para que o corpo assumisse a forma andrógina, experimentos semelhantes aos que utilizaram ao colonizarem a Terra.

\subsection{A forma do romance e as possibilidades da imaginação utópica}

A forma do romance é constituída por distintos gêneros narrativos - nas páginas do livro, encontramos a narração em primeira pessoa feita pelo Primeiro Móvel Genly no desempenhar

${ }^{10}$ A primeira vez que foi isolado um gene ocorre no ano da publicação do romance, na Universidade de Harvard, em Boston, sob a direção do bioquímico Jonathan Beckwith. 
de sua missão, o diário de Estraven, natural de Gethen/Inverno, o relatório prévio de investigadores do Ekumen, as lendas de Karhide e parábolas, as observações técnicas como um apêndice sobre o calendário e o relógio gethenianos.

Seguem cinco excertos exemplificativos:

(1) E no Centro não existe tempo passado, nem tempo futuro. O Centro está em todo o tempo passado. E está em todo o tempo futuro. Não foi e nem será. O Centro é tudo. [Provérbios de Tuhulme, um livro do cânone yomeshita escrito no Orgoreyn Norte há 900 anos. (LE GUIN, 2005, p. 157)]

(2) Observações do ponto de vista social: muito superficiais, até agora: tenho me deslocado demais para fazer observações sociais coerentes. [Nota de campo de Ong Tot Oppong, investigadora do primeiro grupo pertencente ao Ekumen, vinda do planeta Terra com missão Gethen/Inverno ciclo 93 A.Y. 1448. (LE GUIN, 2005, p. 93)]

(3) Ottormenbod Thern. Nevando neserem. Dormimos o suficiente. Ai me ensinou um jogo terráqueo chamado Go, jogado em tabuleiros com pequenas pedras, um jogo excelente e complexo. Como ele observou, há pedras de sobra aqui para se jogar Go. [Diário de Estraven, o getheniano que acompanhará Genly Ali na cruzada do Gelo Gobrin, a área mais gélida do planeta.(LE GUIN, 2005, p. 215)]

(4) Atiraram para matar. Estraven estava morrendo quando cheguei, caído e retorcido, separado de seus esquis, que estavam fincados na neve, metade do peito despedaçado pelo disparo. Segurei sua cabeça em meus braços e falei com ele, mas não me respondeu; apenas de um modo reagiu a meu amor, gritando, em meio aos silenciosos e destroços e tumultos de sua mente, à medida que sua consciência se esvaía, na linguagem muda, uma vez, claramente - Arek! - Depois, mais nada. [Narração do enviado Genly Ali. O trecho possui o tom de uma space opera ${ }^{11} \mathrm{e}$ trata da perseguição sofrida e o autossacrifício final do getheniano Estraven para salvar Genly. No excerto, é possível observar as questões do amor entre espécies e da tecnologia telepática, que possibilitaria uma troca mais íntima de mensagens, ambos temas clichês do gênero SF. (LE GUIN, 2005, p. 273)]

(5) Ano. O período da revolução de Gethen é de 8401 Horas-padrão Terrestres, ou 0,96 do Ano-padrão Terrestre. [Excerto final, a respeito das medidas de tempo do calendário e o relógio gethenianos. (LE GUIN, 2005, p. 293)]

Embora haja um enredo central - os fatos encadeados a respeito da missão de Genly Ali, que são narrados tanto pelo próprio Enviado quanto pelo getheniano Estraven ${ }^{12}-$, é digno de

\footnotetext{
${ }^{11}$ Termo utilizado para se referir pejorativamente e/ou nostalgicamente a alguns escritos de FC que se assemelhariam às soap operas - rádio- e telenovelas.

${ }^{12}$ Ursula Le Guin não faz uso de linguagem inclusiva em seu romance ao mencionar seres ambisexuais e assim a segue, de forma acertada, a tradução ao português. Neste trabalho, também foi observada a diretriz de declinar de forma tradicional o gênero das palavras (e não se usar a marcação com x), pois se considerou dois aspectos: a crítica a respeito da autora nem sempre utiliza esta norma bastante recente e como há quantidade considerável de vocábulos próprios do universo hainiano de Le Guin, o uso das terminações em x poderiam causar ruídos na leitura.
} 
atenção o rompimento entre os estilos textuais utilizados no livro. Os capítulos que elucidam com dados técnicos, antropológicos e religiosos a vida, as ideologias e as tradições de Gethen/Inverno movimentam materiais que não seriam cabíveis na forma narrativa do considerado romance tradicional. Mais do que contar uma história, o romance apresenta um modo de vida alienígena e questiona a nossa própria maneira de viver. Nesta arquitetura formal, a ação já não mais é preponderante - todos os excertos contribuem para a reflexão do leitor sobre as principais questões postas.

Uma vez ressaltados os diferentes gêneros textuais que formam o romance, um ponto de unidade entre eles diz respeito ao espaço. Os textos são restritos ao mesmo planeta Gethen/Inverno, cujas temperaturas médias são baixíssimas, um desafio à sobrevivência de seus habitantes e também ao resto da humanidade ekumênica. Todo o romance faz referência ao meio ambiente gélido, árduo para a sobrevivência de espécies humanoides, em que o frio constante se impõe a todo o momento.

As observações finais de Ong Tot Oppong, investigadora do primeiro grupo ekumênico sobre o planeta Inverno, são as seguintes:

(...) na verdade, não consigo ver como alguém poderia dar muito valor à vitória e à glória depois de passar um inverno em Inverno e ver a face do Gelo. (LE GUIN, 2005, p. 97)

Genly Ali, o Enviado, possui sempre dificuldades em se adaptar às condições climáticas - em suas próprias palavras:

O rei parece ter terminado seu trabalho de pedreiro, e me alegro; mas, atravessando sob a curva do arco em sua teia de tábuas, ele começa a trabalhar do outro lado da pedra-chave, que, afinal, tem dois lados. Não adianta ser impaciente em Karhide. Eles são tudo menos um povo fleumático, contudo obstinados, pertinazes, e terminam de rejuntar juntas. A multidão na Margem do Sess anima-se ao ver o rei trabalhando, mas estou entediado e com calor. Jamais havia sentido calor em Inverno; jamais sentirei de novo; contudo, não consigo apreciar o evento. Estou vestido para a Era Glacial e não para o calor do sol, em camadas e mais camadas de roupas, tecidas em fibras vegetais, fibra artificial, peles, couro, uma armadura maciça contra o frio, dentro da qual, agora, murcho como uma folha de rabanete. (LE GUIN, 2005, p. 15)

Como em todos os mundos inventados, LHD desperta uma irresistível reminiscência do real; segundo Fredric Jameson, uma espécie de "Moscóvia de Eisenstein", em seu ensaio World reduction in Le Guin: the emergence of utopian narrative, de 1975, que irá compor o livro Archeologies of the future de 2005 . O crítico traça uma reflexão a respeito da tradição literária de 
língua inglesa e os sentidos do "calor intenso" para chegar à ecologia gélida de Gethen/Inverno: o calor, como o sentido dentro de uma selva, sugere que o corpo seja desmantelado, tenha seus limites desmanchados, a selva como um organismo imenso pelo qual o corpo humano corre o risco de ser absorvido, o medo da perda da autonomia física - aspectos envolvidos no discurso britânico a respeito da desmoralização colonial regada a uísque, uma dissolução física e inclusive moral embutida na mensagem eurocêntrica e fóbica a respeito da ameaça que reside no modo de vida das massas do Terceiro Mundo, que poderiam se colocar contra a prosperidade e os privilégios das nações hegemônicas (e com temperaturas médias muito mais frias). Para Jameson, o frio simbólico teria, assim, uma interpretação relacionada à autonomia do organismo, a separação praticamente total entre corpo e seu entorno, o isolamento entre indivíduos e o fazer de cada recurso interno um forno autossuficiente para a vida.

Entretanto, o frio, pensado como uma extrapolação e levado às últimas consequências, acaba por apontar ainda um processo mais interessante, que Le Guin utiliza em outros momentos da obra - a extirpação, quase cirúrgica, de certo aspecto da realidade empírica, uma operação de abstração e simplificação radical que Jameson denominará de "redução do mundo". Trata-se de um processo criativo em que se recorta e ressalta dada característica da realidade, de forma a atenuar, ontologicamente, a sua imensa gama de possibilidades, e reduzindo-a a um mínimo.

O processo de "redução de mundo" seria utilizado, segundo Jameson, não apenas com relação ao frio, mas também à inexistência de outros animais no planeta - na ficção, isso reforçaria a hipótese de que os gethenianos seriam uma experiência genética, e mesmo com relação às questões relacionadas a sexo: suprime-se drasticamente a "problemática relacionada ao desejo" imagina-se que, como o desejo é reduzido a alguns dias e pode ser satisfeito, não haveria distúrbios relevantes de ordem sexual, dado que negar o desejo tem raízes tão antigas como o próprio desejo sexual. ${ }^{13}$ Acrescente-se ainda, ao rol de supressões fornecidas por Jameson, a ausência de expansão comercial ou territorial por parte dos gethenianos, os quais não conhecem a guerra, embora conheçam a inimizade entre dois povos.

O fio condutor do texto de Jameson traz a proposta teórica, então, de que um dos campos de prova para as obras de Ursula Le Guin, em particular The left hand of darkness e The dispossed,

\footnotetext{
13 Jameson não menciona explicitamente a relação incestuosa entre irmãos que resulta em filhos, que move parte da narrativa de Estraven e poderia ser uma exceção.
} 
não seria a construção da utopia propriamente dita e sim questionar a nossa própria capacidade para concebê-la, considerando a maneira pela qual Le Guin tenta construir sua utopia por processos de supressões sucessivas (supressão de outros animais, supressão do desejo, supressão do desejo de expansão comercial e territorial por parte dos gethenianos etc.).

$\mathrm{O}$ título The left hand of darkness refere-se também a um mecanismo de redução de mundo. A frase é retirada de um verso da religião handara, praticada pelos habitantes de Karhide, um culto ao desconhecimento, privar a mente de todos os elementos não essenciais. Um dos propósitos fundamentais da prática ritual é predizer o futuro. Entretanto, a previsão futurológica possui uma limitação bem clara: apesar de ser possível perguntar qualquer coisa aos respondedores, é recomendável pela religião que não se faça isso. Aqui atua novamente o mecanismo de redução de mundo - embora seja possível perguntar qualquer coisa, é necessário que se evite fazer as perguntas cujas respostas são impossíveis de se imaginar, o que seria, em última análise, conseguir imaginar a própria utopia. Dessa forma, a religião ressalta a "inutilidade de conhecer a resposta para a pergunta errada" e, levando mais longe, ressalta-se a inutilidade de se fazer perguntas em geral. Citando o romance, segue excerto do diálogo entre o sacerdote Faxe e o Enviado Genry Ali:

- Bem, vivemos nos Retiros principalmente para aprender quais perguntas evitar.

- Mas vocês são os Respondedores!

- Ainda não percebeu, Genry, por que aperfeiçoamos e praticamos a Vidência?

- Não...

- Para demonstrar a completa inutilidade de saber a resposta para a pergunta errada. (LE GUIN, 2005, p. 73)

Segundo o raciocínio de Jameson, saber quais perguntas são impossíveis de responder e não as fazer: esta habilidade é supremamente necessária em tempos de tensão e obscuridade. (JAMESON, 1975). Como o motor da narrativa é ligado à ideia de "ignição histórica", a vinda do Enviado altera definitivamente o gélido planeta, desencadeando em Inverno a avalanche de lutas que pareciam adormecidas. O que sairia no final de uma suposta guerra? Um feudalismo karhideano? Um estado capitalista orgoreyniano? A narrativa estanca e termina antes de obtermos a resposta. As perguntas ficam suspensas no ar e o Enviado não poderia proferi-las. A astúcia da enunciação, construída por meio dos gêneros literários alternados, faz com que, coincidentemente, a narrativa comece no exato momento em que o Enviado chega. Também se finda com sua partida, 
configurando algo como "a 'História' prossegue com o término da 'estória", apontando para uma "narrativa maior" dentro da narrativa de um homem só. Conforme Fredric Jameson: ante o enclave para romper um círculo vicioso que é estar entre as opções de um feudalismo e de um capitalismo, qual seria a saída? Entrar para o Ekumen? Colocar a estratégia de não fazer perguntas não é a melhor maneira de resguardar a imaginação utópica contra o retorno a essas contradições históricas. $^{14}$

\subsection{Resumo sobre os dados editoriais}

LHD foi publicado em 1969, pela editora Ace Books. Para fornecer uma ideia do contexto editorial, a Ace Books, fundada em 1952, tinha por objetivo publicar livros de gêneros considerados "literatura menor", como suspense, western e pulp magazines. Após 1960, já publicava, majoritariamente, ficção científica. Junto com outra editora, a Ballantine Books, era uma das principais divulgadoras do gênero, com obras de Philip K. Dick, Robert Bloch, Jack Vance e outros. Os livros eram de baixo custo e vendidos por menos de um dólar - em 1967, o grosso volume de Duna, de Frank Herbert, foi comercializado por 95 centavos de dólar, aproximadamente US\$ 6,65 em valores de 2012. Com o falecimento de seu proprietário, Aaron A. Wyn, a Ace Books teve sucessivos problemas financeiros, sendo adquirida por Grosset \& Dunlap e depois por G.P. Putnam's Sons. Desde 1996, pertence ao grupo Penguin.

\footnotetext{
14 "But, of course, the real alternative to this dilemma, the only conceivable way of breaking out of that vicious circle which is the option between feudalism and capitalism, is a quite different one from the liberal "solution"-the Ekumen as a kind of galactic United Nations-offered by the writer and her heroes. One is tempted to wonder whether the strategy of not asking questions ("Mankind," according to Marx, "always [taking] up only such problems as it can solve") is not the way in which the utopian imagination protects itself against a fatal return to just those historical contradictions from which it was supposed to provide relief. In that case, the deepest subject of Le Guin's LHD would not be utopia as such, but rather our own incapacity to conceive it in the first place" (JAMESON, 1975).
} 


\section{Capítulo 3 - The Handmaid`s Tale: nostalgia e resignação}

\subsection{As narrativas que formam "O conto da aia"}

Como análises literárias não são exatamente conhecidas pelo seu suspense, comecemos a interpretação do romance pelo seu final: em tom estridente, grandiloquente e irritante, nas últimas páginas do livro apresenta-se o principal narrador do romance $O$ conto da aia, que mais soa como um apresentador de show de variedades da programação televisiva de domingo à tarde, o qual ainda se revela um renomado acadêmico, o Professor James Darcy Pieixoto, da Universidade de Cambridge.

Esta segunda e curtíssima parte do romance, "Notas históricas sobre $O$ conto da aia", apresenta-se na forma de um relatório, "consistindo em uma transcrição parcial das atas do Décimo Segundo Simpósio sobre Estudos de Gilead", (ATWOOD, 2006, p. 351) em congresso acadêmico no futurístico dia 25 de junho de 2195.

Primeiramente, nosso narrador é introduzido pela presidente do Simpósio, Professora Maryann Lua Crescente, do Departamento de Antropologia Caucasiana da Universidade de Denay, com as seguintes palavras:

É com grande prazer que dou as boas-vindas a todos os presentes aqui esta manhã, e estou muito satisfeita por ver que tantos dos senhores compareceram para ouvir a apresentação do professor Pieixoto, que, tenho certeza, será fascinante e valerá a pena ser ouvida. Nós da Associação de Pesquisa de Gilead acreditamos que este período é rico em recompensar o estudo adicional, por ter sido responsável como foi, em última instância, por redesenhar o mapa do mundo, especialmente neste hemisfério. (ATWOOD, 2006, p.351)

A apresentadora dá recados para os presentes ao seminário, faz piadinhas para que o Prof. Pieixoto respeite o tempo para que ninguém perca o almoço "como aconteceu ontem (risos)" e enfim passa a palavra para o acadêmico, que irá proferir a palestra "Problemas de Autenticação com 
Relação a $O$ conto da aia". A plateia, que se comporta como a de um programa de auditório, escutao atentamente e recebe cada uma de suas falas com aplausos e congratulações.

Com um ar que vai da troça à empáfia, o Professor Pieixoto faz, finalmente, a grande revelação do romance: o que líamos até o momento não passava de uma reconstituição histórica de um relato que ele e outro acadêmico, Professor Knotly Wade, realizaram em conjunto. O material bruto consistia em trinta fitas cassetes cujo conteúdo fora transcrito e organizado da maneira que os dois acadêmicos julgaram mais apropriada.

A revelação é bastante chocante para quem, até então, lia o lamentoso relato da aia Offred, narrativa que ocupa $90 \%$ das páginas anteriores do livro. A narrativa dramática da aia relata a perda de todas as liberdades individuais que possuía nos Estados Unidos até ter sido reduzida a um útero a serviço de Gilead, estado teocrático sucessor dos então Estados Unidos da América. A figura caricatural do narrador Pieixoto, cujo discurso faz arrepiar qualquer simpatizante de direitos humanos, não deixa nenhuma dúvida sobre seu deboche a respeito dos augúrios da pobre Offred, agora reduzida a mero objeto histórico.

A inversão proposta - de iniciar a análise do romance pelo seu final - confere acréscimos às interpretações mais consolidadas sobre a obra: as críticas mais reconhecidas sobre o romance frisam a figura de Offred e seu relato, minimizando a importância da impactante revelação sobre quem efetivamente organiza o relato, um homem machista.

Um exemplo deste ponto de vista mais tradicional seria o da crítica Coral Ann Howells, referência em estudos sobre a autora. Em seu ensaio Science fiction in the feminine: The handmaid's tale, a crítica sublinha a importância de Atwood em ressaltar as habilidades de "narrar histórias" de suas personagens femininas, como um ato de resistência, o que ocorreria em The handmaid's tale e em Bodily harm:

Embora restrita a espaços privados e domésticos e relegada às margens de uma estrutura política que lhe nega sua existência como indivíduo, Offred assegura o seu direito a contar a sua história. (HOWELLS, 1996, p.127)

Entretanto, neste trabalho, a ideia da interpretação é entender essa moldura narrativa como parte inseparável do todo que é o romance. Em lugar de se idealizar a narrativa de Offred como um "ato de resistência" e se aferrar à narrativa dramática, cuja presença seria tão ofuscante a ponto de nublar a segunda e curtíssima parte, a tentativa é ler o romance como ele se apresenta, em 
sua maneira mais cruel e distópica: não obstante o sofrimento da Aia, suas memórias são reorganizadas e editadas por dois homens sem escrúpulos e ainda de prestígio.

Esta possibilidade de leitura confere um ganho interessante no estudo da forma do romance. Forma é compreendida aqui na lição de Roberto Schwarz ao analisar outro defunto autor (SCHWARZ, 2000, p. 18), tomando o termo forma em dois sentidos, (a) como regra de composição da narrativa, e (b) como estilização de uma conduta própria da sociedade que a produz. Se nos afastarmos um pouco e recusarmos cair no canto da sereia do drama da Aia, será possível "entrever as grandes linhas de uma estrutura social” (SCHWARZ, 2000, p. 19), não de Gilead, claro, mas da visão hegemônica da sociedade da América do Norte atual.

Regressemos ao nosso desagradável narrador. Ao dar boas-vindas ao público do Simpósio, já demonstra um espírito afeito a um tipo de humor bem peculiar:

Tenho certeza de que nós todos tivemos grande prazer em apreciar nossa charmosa e saborosa truta do Ártico ontem à noite no jantar, e agora estamos tendo o prazer em apreciar nossa igualmente charmosa presidente do Ártico. Emprego aqui a palavra "apreciar" em dois sentidos distintos, excluindo é claro, o terceiro, obsoleto. (Risos). (ATWOOD, 2006, p. 353)

O acadêmico então revela que, em conjunto com o Professor Wade, transcreveu, compilou e organizou trinta fitas que continham o depoimento da aia Offred, séculos após este relato ter sido proferido: "depois de termos a transcrição em mão - e tivemos que refazê-la e revisála várias vezes, devido a dificuldades criadas por sotaque, referências obscuras e arcaísmos tivemos que tomar algumas decisões quanto à natureza do material que havíamos tão laboriosamente adquirido" (ATWOOD, 2006, p. 355). Batizam o relato como "The handmaid's tale" em homenagem a The Canterbury tales de Chaucer, com um gracejo melhor compreensível no original, a partir da proximidade de "tale", conto, e "tail", rabo, partes íntimas, no original:

(...) those of you who know Professor Wade informally, as I do, will understand when I say that I am sure all puns were intentional, particularly that having to do with the archaic vulgar signification of the word tail; that being, in some extent, the bone, as it were, of contention, in that phase of Gileaden society of which our saga treats. (Laughter, applause). (ATWOOD, 2006, p. 313)

Entretanto, a "piada" é bem mais complexa e seu total entendimento depende de a audiência saber mais a respeito da considerada literatura culta de língua inglesa: realmente, Chaucer possui um trocadilho que envolve o som "tail", mas está em The shipman's tale - uma esperta 
esposa paga a dívida com o marido deitando-se com um monge conhecido, quando sua taille, "tail", partes pudicas, é um "tally", livro de contabilidade ("score it upon my taille”) . Na crítica de Arnold Davidson, que elucidou o trecho:

The whole title of the narration is appended by Professor Wade, "partly in homage to the great Geoffrey Chaucer" but also as an intentional pun on "the archaic vulgar signification of the word tail". Yet it is those little jokes that give the larger game away. The grotesque transformation of women's bodies into passive receptacles for the perpetuation of the genes of Regime's Commanders is itself grotesquely transmogrified, in the twenty-second century, into silly sexist jests. (DAVIDSON, 1988, p. 115)

O uso do tom pernóstico do narrador bastante inoportuno parece, contudo, não macular a narrativa dramática principal que antecede a palestra do Prof. Pieixoto. O contraste entre esta parte do romance e a anterior é notável. Entretanto, os rumos do livro estão claramente definidos: se o leitor ou leitora achou um completo horror o que acontece com a aia Offred é porque não imagina que, mesmo depois dessa hecatombe toda, no ano de 2195, ao menos para as mulheres com carreira acadêmica no mundo ocidental, as coisas parecem que continuam bem comuns se comparadas ao ano de 2015. Aliás, relendo o trecho com esta perspectiva, a narrativa de Pieixoto se assemelha muito a experiências de simpósios científicos mal-organizados dos dias de hoje.

O ponto que unifica então as duas partes do romance é a narradora-personagem Offred. A primeira parte do romance, $O$ conto da aia propriamente dito, é escrita em fragmentos de experiência em primeira pessoa, com cunho biográfico, com muitas digressões. Em entrevistas posteriores, a autora reitera sua escolha em fazer com que o relato soe como reconstituição de gravações em fitas cassetes, pois também estariam relacionadas “à natureza descontínua e episódica da narrativa”. A escolha do tom e vocabulário se faz a mais coloquial possível, conforme a autora: "a personagem contando a história foi criada em nosso tempo, em nossa linguagem" (INGERSOLL, 2006, p. 115).

Sobre Offred não sabemos muito, nem mesmo seu nome real (o nome "Offred" refere-se ao Comandante a quem serve, Fred, do inglês "of Fred" - caso venha a servir outro senhor, como Charles, seu nome viraria Ofcharles). Sabemos de sua ocupação: as "aias" são mulheres aptas à maternidade. Neste tempo fictício de Gilead, a grande maioria das mulheres é estéril, sendo a fertilidade um valor a ser preservado pelo Estado teocrático. As mulheres são confinadas a trabalhos domésticos e divididas por classe social, sinalizada pelas cores das vestimentas: azuis para as 
"Esposas", vermelho para as "Aias", verdes para as empregadas "Ritas", cinza para as expulsas, que fazem trabalhos forçados. Há ainda prostitutas, que se vestem como preferem.

O que sabemos da narradora é que se trata de mulher branca, de 33 anos, de classe média norte-americana. Conforme nos adverte Prof. Pieixoto:

Ela parece uma mulher instruída tanto quanto se poderia dizer que qualquer pessoa diplomada por uma faculdade norte-americana da época fosse instruída (Risos, alguns gemidos). Mas as classes trabalhadoras brancas, como se costuma dizer por aqui, eram repletas de mulheres como ela, de modo que isso não ajuda em nada. (ATWOOD, 2006, p. 359)

A única narradora parece ser uma americana "normal”, uma "mulher ordinária" (HOWELLS, 1996, p. 15). Não é tolerável que, após a insistência de movimentos de mulheres latinas, mulheres negras e mulheres que habitam periferias, essa "normalidade" da personagem branca, norte-americana e de classe média de Offred passe sem ser questionada. Inclusive, sendo o romance lido do Brasil, temos um bom modelo de crítica como termômetro desta suposta “normalidade" de Offred: a lição que consta em Duas Meninas de Roberto Schwarz.

Ele aponta momentos nos quais os estudiosos de Dom Casmurro não prosperam nas análises por não repararem em sua própria identificação com Bentinho (SCHWARZ, 1994). Schwarz aponta como a crítica machadiana anterior "de ânimo patriarcal e policial, à cata de prenúncios e evidências do adultério, dado indubitável", não é capaz de identificar a narrativa unilateral e trata o narrador em primeira pessoa como "cidadão acima de qualquer suspeita" e

(...) se deixa seduzir pelo prestígio poético e social da figura que está com a palavra. Aliás, como recusar simpatia a um cavalheiro distinto e sentimental, admiravelmente bem-falante, um pouco desajeitado em questões práticas, sobretudo em dinheiro, sempre perdido em recordações da infância, da casa onde cresceu, do quintal, do poço, dos brinquedos e pregões antigos, venerador lacrimoso da mãe, além de obcecado pela primeira namorada? (SCHWARZ, 1994, p. 10).

Dessa forma, uma das vantagens da leitura de HT feita no Brasil é colocar sob suspeita a identificação imediata de parte da crítica com a narradora Offred e suas mazelas e não aceitar a aia como se fosse uma representante "universal" para o sofrimento das mulheres no patriarcado. 


\subsection{Vertentes críticas sobre o romance: backlash e utopia}

Sendo considerado leitura obrigatória em escolas e universidades em países de língua inglesa, The handmaid's tale apresenta uma fortuna crítica bastante considerável apesar dos joviais 30 anos da publicação. A obra da autora é objeto de muitos livros de crítica e quase todos se referem a HT como central na primeira fase de sua produção, um dos livros responsáveis em colocar Atwood como referência na recente literatura canadense.

É importante esclarecer que muitos livros considerados de crítica apresentam cunho muito mais informativo do que estritamente crítico e poderiam ser considerados como obras de divulgação da autora - referimo-nos principalmente às obras de Coral Ann Howells (2005, 2006), Earl Ingersoll (1990 e 2006) e Reingard Nischik (2002 e 2009). No mais, ao contrário do que ocorre em LHD, em que a crítica irá alterar os temas estudados com o passar do tempo, a crítica sobre HT é praticamente unânime em considerar o tema feminismo logo de saída, quase não se encontrando material que não se refira explicitamente ao tema, inclusive, muitos teóricos são bastante específicos a respeito das questões sobre a militância feminista que o romance suscita. Aliás, um dos acréscimos deste trabalho é a tentativa de pensar HT um pouco além desta moldura, incluindo na análise da obra o questionamento sobre a distopia política que apresenta. Assim, nesta revisão da fortuna crítica, elegeu-se apontar as maneiras pelas quais diferentes correntes do feminismo são representadas no romance e os desdobramentos a respeito do tema utopia.

A palavra central para se compreender a recepção crítica é backlash - conceito desenvolvido por Susan Faludi e incorpora-se, hoje em dia, como termo de uso corrente na militância feminista, um movimento cultural para condenar qualquer mulher que saia do padrão prescrito às "mulheres honestas":

Nos anos 80, o backlash andou pelos subterrâneos secretos da cultura, circulando pelos corredores da bajulação e do medo. Ao longo do caminho usou vários disfarces: desde a máscara de uma condescendente ironia até a expressão sofrida da "profunda preocupação". Os seus lábios demonstram piedade por qualquer mulher que não se enquadre na moldura, enquanto procura prendê-la na moldura. Professa uma estratégia de cizânia: solteiras contra casadas, mulheres que trabalham fora contra donas-de-casa, classe média contra operárias. Manipula um sistema de punição e recompensa, enaltecendo as mulheres que seguem as suas regras, isolando as que desobedecem. $\mathrm{O}$ backlash revende velhos mitos sobre as mulheres fazendo-os passar por fatos novos, ignorando qualquer apelo à razão. Acuado, nega a sua própria existência, levanta um dedo ameaçador contra o feminismo e procura desaparecer nos subterrâneos (FALUDI, 1992, p. 21). 
Parte considerável das leituras a respeito do romance considera a obra fruto deste espírito dos tempos e inicia a análise a partir desta ocorrência. Á época, um dos problemas para a militância feminista a respeito do fenômeno do backlash nos anos de 1980 era conseguir “comprová-lo", pois a nova onda de repressão ocorreria no âmbito cultural, sendo menos visível. A própria Atwood teria feito um clipping de notícias sobre ataques aos direitos das mulheres, material que a autora carregava consigo em eventos como prova de que "não havia inventado nada em Gilead". Em 'Just a Backlash': Margaret Atwood, Feminism, and The Handmaid's Tale (NEUMAN, 2006), é retratado o clima de caça às bruxas feministas instaurado na mídia, nas famílias, nas ruas, que irá ser incorporado na publicação:

The media began to announce that the world had moved into a 'post-feminist' era, while at the same time it gave wide circulation to a number of badly designed, badly analysed, badly misrepresented, or dishonestly co-opted studies claiming to prove that single career women had high rates of neuroses and unhappiness, that women's incomes declined an average of 70 per cent post-divorce, that the United States was in the grip of an 'infertility epidemic,' that a professional woman over thirty was about as likely to win a lottery jackpot as to find a man (see both Faludi and Bouson). Across North America, young women in universities, in the confidence born of their mothers' success, in the desire for self-differentiation that ever characterizes the young, overly credulous of the media and perhaps anxious to find a man, asserted that they didn't need feminism.

É possível afirmar que o romance é lido como representação do momento histórico do backlash, marcado também pela falta pelas subdivisões do movimento feminista e pelo aumento das tensões internas entre grupos por questões bastante específicas - é notório também o enfraquecimento do elo entre as militâncias feministas e de esquerda, o que será mais bem detalhado no Capítulo IV. Essas repartições da militância acabam por facilitar o contra-ataque das correntes conservadoras. Em HT, encontram-se retratados muitos dos problemas mais imediatos da militância feminista. Segundo Neuman (2006), a personagem de Offred incorpora este espírito da geração, tendo muitas vezes vergonha da atitude de sua mãe militante feminista e julgando como temerários os arroubos da amiga Moira. Alanna Callaway exemplifica a respeito da questão da falta de solidariedade que marca o período:

"The Handmaid's Tale" paints the conservative revival as stemming partly from a lack of female solidarity characterizing the Second Wave of the Women's Liberation Movement. Feminist theorist bell hooks has argued that "although [the] contemporary feminist movement should have provided a training ground for women to learn about political solidarity, Sisterhood was not viewed as a revolutionary accomplishment women would work and struggle to obtain". For 
hooks and for Atwood this was one of the most destructive tendencies of SecondWave Feminism. Without solidarity, without sisterhood, women are not united. If women are disunited they have little hope of making the lasting revolutionary changes they see as necessary for social improvement. Unwittingly, then, they become agents of the oppressive social order they wish to escape. Because feminists allowed themselves to be divided over issues of identity, for example, the entire movement appeared weak and more vulnerable to attack (CALLAWAY, 2008).

Grande parte da crítica, então, considera que o trabalho de Atwood foi potencializar o que já existia para mostrar onde o backlash poderia chegar, inclusive sem esquecer as contradições internas ao movimento feminista. Fiona Nolan (2005, P. 19) foi atenta a isso em seu Feminist Utopias and Questions of Liberty: Margaret Atwood's The Handmaid's Tale as Critique of Second Wave Feminism:

In "The Handmaid's Tale", Aunt Lydia and Offred's mother, despite massive differences in their political convictions, both advocate a philosophy of positive freedom. The societies that they envision*/ fundamental Christian and radical feminist*/both necessitate a form of governance that prescribes for its subjects. Moira, however, is an advocate of negative freedom. Her activities, while strictly feminist and super-ficially close to those of Offred's mother, involve demands for freedom of action but are lacking the prescriptive element of the earlier feminists. The burning of books symbolizes this shift: the attempt by Offred's mother to censor and destroy sexualized images of women later becomes, with Moira, a postmodern impulse to subvert and defuse the porno-graphic image, as she organizes 'an underwhore party': 'You know, like Tupperware, only with underwear. Tart's stuff' (Atwood 1985:66). However, with her embrace of lesbianism, Moira's feminism reverts to positive freedom as she charges Offred with perpetuating patriarchy by entering into a heterosexual relationship. With this, Atwood suggests that the persistent utopianism of feminism perpetually endangers feminist liberalism.

Uma das ocorrências mais interessantes, contudo, no exame da crítica é verificar como não se aceita completamente o caráter distópico do romance. Como esses textos são redigidos, na maior parte das vezes, por acadêmicos que se dedicam ao tema feminismo e aos estudos de questões de gênero, é bastante recorrente a necessidade - de ordem psicológica ou social - de se enxergar na obra uma proposta utópica onde ela não existe. Aqui se considera que a própria estrutura do romance encerra um fechamento da questão utópica (vide item 3.4), dado que os narradores acadêmicos da segunda parte da narrativa agem com extrema misoginia, ou seja, em 100 anos o mundo não seria melhor segundo as previsões do romance. Mesmo com esta perspectiva, parte considerável da crítica parece esquecer este desenlace e tece considerações bastante animadoras a respeito das configurações utópicas da obra. Ocorre o fenômeno já mencionado que é a crítica se identificar com a obra, principalmente com a narradora Offred (seria lida como a 
"mulher sofredora universal”), e não conseguir mais ler a obra com distanciamento. Estes achados de emergências de (falsas) utopias são encontrados em vários níveis de análise - na própria representação da distopia, na forma do romance e nas características da narradora-heroína. Neuman (2006) é um exemplo deste movimento e afirma que o livro, ao final, encerraria em si um primeiro passo à utopia, um mundo que não seria nem Gilead, nem a vida atual. Em sua conclusão:

The implicit women's utopia of "The Handmaid's Tale" is not in 'the time before.' It exists outside the 'either/or' thinking so beloved of Aunt Lydia, and outside the novel: outside of the dangers, humiliations, inequities, and backlash that women experience in its 'time before,' but also outside totalitarian Gilead's claims to have improved their lot. A first step to utopia, Atwood's novel tells us, requires that we 'pay attention' and bear witness, as does Offred when she uses her uncertain freedom to tell her story.

Outro exemplo deste ponto de vista um pouco idealizado a respeito do romance seria o de Sarah Morrison (2000), que afirma que Atwood conseguiria retirar da forma tradicional dos romances escritos para mulheres fundamentos para recriação do gênero e conferindo novas possibilidades à representação das mulheres:

In their continued efforts to escape from the influence of women's romantic fiction, women writers repeatedly seem to discover that such escape is impossible; sometimes they pause to wonder whether such escape is even desirable. Atwood and Schaeffer (to borrow Epstein's phrase) "strike a" "bargain. . . with the romance plot"(p. 91). They expose the dangerously seductive elements of women's romantic fiction by showing how their heroines are paralyzed or trapped by the old plots, but they avoid the attack on women's romantic fantasies that becomes an attack on women themselves for succumbing to them. Atwood and Schaeffer do not treat the form or substance of women's romantic fiction with disrespect, but rather point to its profound significance, instilling their work with new power through the force of old forms.

Em um terceiro exemplo, muito valor foi dado ao fato de Offred simplesmente ter a faculdade de narrar em uma situação tão opressora (a esse respeito há muito material crítico, inclusive comparando a mulheres em regimes totalitários hoje, com algumas inclinações antiislâmicas, diga-se de passagem). Em Margaret Atwood's The Handmaid's Tale: resistance through narrating, Hilde Staels (1995) esmiúça as formas discursivas recorrentes em HT, o uso da primeira pessoa e a composição do texto narrativo, comparando o estatuto discursivo da teocracia em Gilead e o discurso pessoal e estético da aia, em uma crítica bastante romantizada sobre o poder do ato de narrar como forma de resistência contra regimes autoritários, mas com conteúdo muito repetido em bancos de artigos acadêmicos: 
By giving expression to her inner feelings and bodily sensations from her situation on the periphery of society, Offred breaks through the discursive Law od the theocracy. Gilead censors the threatening force of creative self-expression. Yet Offred defies the strict rules of authoritative discourse by giving life to a silenced discourse. She revives the capacity for individual spiritual and emotional life. In the margin, she speaks in her own name, the name that she was supposed to forget once and for all: 'I keep the knowledge of this name like something hidden, some treasure I'll come back to dig up, one day. I think of this name as buried'.

Mais interessante sobre este ponto específico são as considerações de "Trust Me": Reading the Romance Plot in Margaret Atwood's "The Handmaid's Tale”, em que a autora Madonne Miner (1991) problematiza a ideia da narradora-testemunha e sugere que o romance é bem ambíguo em relação à atuação dos personagens (algumas metáforas e conexões parecem trazer chaves para se colocar as histórias de Offred sob suspeita), argumento bastante inovador na análise:

Sadly, both of the reconstructions she[Offred] offers us, as well as the fairly-tale construction she employs when she thinks about this affair, limit the range of activities and options available to male and female characters. Operating within this traditional grammar (men are princes or made of darkness; women are princesses or damsels in distress), Offred can individuate neither herself nor Nick; both fall into roles assigned to them by fairy tales and romances. Is the novel's reliance upon fairy tale/romance paradigms so destructive as to counteract its positive representation of Nick as "the prince" - the daring young man who saves the maiden? "Counteract" may be too strong a claim, but I argue that every representation of romance in "The Handmaid's Tale", including that most positive representation, Nick with Offred, is highly qualified, highly ambivalent. The novel seems to want to believe in its own novelistic representations of love (and, by implication, in "real-life" love) at the same time it expresses extreme reservations about how we (authors, characters, readers, real-life lovers) typically realize this emotion.

Resumindo-se, dentro de um panorama crítico com uma produção bastante numerosa, ainda há muitas possibilidades de leituras argutas sobre o romance. Principalmente que coloquem a obra além de demandas específicas da militância feminista da segunda onda, que sejam mais rigorosas em evitar a identificação com a "vítima Offred" e, em terceiro, que enfrentem o fato de Atwood ter escrito, nas palavras de Jameson, "a primeira distopia feminista" e não se ocultar o caráter liberal do feminismo representado na obra - estas posturas poderiam oferecer chaves interpretativas de maior fôlego. 


\subsection{A nostalgia e o tabu: poderiam os EUA ter originado Gilead?}

“Talvez eu esteja louca e isto seria algum novo tipo de terapia. Gostaria que fosse verdade; então eu melhoraria e isto acabaria" (ATWOOD, 2006, p. 177). Nesta nova sociedade totalitária de Gilead, nossa narradora Offred não possui nenhuma liberdade. Está sob custódia do Estado, infeliz, acuada, amedrontada, sempre à espera que façam o uso de seu útero sadio para prover crianças a famílias abastadas. Ocupa um lugar que poderia ser análogo à classe média, considerando que não lhe cabe árduos trabalhos e que, na lógica teocrática e absurda de Gilead, as aias seriam privilegiadas por suas ocupações "nobres".

Para dar vida à protagonista, foi preciso trazer à cena um elenco de personagens que, em certo plano, resume a sociedade norte-americana: "Esposas" e "Ritas" povoam as casas, nas dinâmicas conhecidas de patroas e empregadas. As "Aias", nesta configuração, estariam em um termo médio, quase como uma filha adolescente cerrada no quarto. Os homens também estão nestas posições: "Comandantes" e "Olhos" (estes podem atuar como seguranças ou motoristas e possuem nome próprio, como é o caso de Nick).

A narrativa da aia em primeira pessoa alterna assuntos em tom de uma prisioneira, ressaltando suas limitações nesta nova sociedade de Gilead. Pode existir um belo jardim na casa em que mora, mas os vidros até o jardim são inquebráveis para que a aia não possa experimentar a fuga ou o suicídio. Ela não precisa fazer trabalhos pesados, mas é fonte de um ódio surdo das serviçais da casa. Seus temas são os que tipificariam a vida de uma mulher branca de classe média sem filhos - narra o fazer compras, o asseio, os pequenos passeios, os detalhes do espaço doméstico. Como uma típica representante da classe média, teme a repressão policial, pois está a sua mercê (o que não aconteceria se pertencesse à elite) e sente "alívio" quando assiste a uma cena brutal de violência a um homem supostamente inocente:

Dois Olhos, de ternos cinzas, saltam pelas portas duplas [da caminhonete] que se abrem na traseira. Agarram um homem com uma maleta, um homem de aparência comum, atiram-no com violência de costas contra a lateral preta da caminhonete. (...) Acabou-se, em segundos, e o tráfego na rua recomeça como se nada tivesse acontecido.

O que sinto é alívio. Não fui eu. (ATWOOD, 2006, p. 206)

Faz digressões entre a sua vida atual e a pregressa, quando Gilead era os Estados Unidos, de maneira a não explicitar a estrutura social vigente maior que a contém, para tristeza dos 
acadêmicos que reorganizaram o seu relato cem anos depois ("poderia ter nos contado muito sobre o funcionamento do império de Gilead, se tivesse tido os instintos de uma repórter ou de uma espiã" [ATWOOD, 2006, p. 365]). Entretanto, esta estrutura narrativa não deixa de exercer o seu poder de determinação, mesmo em se tratando de uma história fictícia e paralela à atual. (SCHWARZ, 2000, p. 71) Sim, Gilead não está tão distante assim, assemelha-se muito aos Estados Unidos das décadas de 1980 e 1990. Exemplificando, o livro inicia-se com uma digressão da protagonista:

Nós dormimos no que outrora havia sido o ginásio esportivo. O assoalho era de madeira envernizada, com listras e círculos pintados, para os jogos que antigamente eram disputados ali; os aros para as redes das cestas de basquete ainda estavam em seus lugares, embora as redes tivessem desaparecido. Uma arquibancada cercava o aposento para os espectadores, e imaginei que podia sentir, muito ligeiramente, como uma imagem evocada, o cheiro pungente de suor, mesclado com a doçura latente de goma de mascar e o perfume das garotas assistindo aos jogos vestidas com saias de feltro, como eu tinha visto em fotografias, mais tarde de minissaias, em seguida de calças, depois com um brinco só, os cabelos espetados com mechas pintadas de verde. Bailes tinham sido realizados ali, um palimpsesto de sons jamais ouvidos, um estilo seguindo-se ao outro, como subcorrente, uma cadência de tambores, um lamento desesperançado, guirlandas feitas de flores de papel de seda, máscaras de cartolina, uma esfera giratória coberta de espelhos, salpicando os dançarinos com uma neve de luz. (ATWOOD, 2006, p. 11)

O trecho trata do espaço físico em que a protagonista está confinada - um ginásio esportivo que, no tempo presente da narrativa, foi convertido em um horrível centro de treinamento para as Aias, mulheres que, nessa ficção, estão sob permanente custódia do Estado teocrático de Gilead.

Tudo o que resta à narradora é o relembrar de tempos idos melhores e de outras possibilidades que acabam por não se tornar realidade ("lembro-me daquele anseio, por alguma coisa que estava sempre a ponto de acontecer" [ATWOOD, 2006, p. 11]). Neste excerto, entretanto, é possível verificar uma distinção bem clara de papéis de gênero na sociedade norte-americana, a partir da descrição das vestimentas das mulheres - dos anos de 1950 ("saias de feltro"), 1960 ("minissaias") a 1970 e 80 (“calças"). Nos três momentos históricos, as garotas somente ficavam na arquibancada, assistindo aos jogos dos meninos, em uma posição passiva, sem protagonismo. Contudo, a narradora não ressalta essa distinção de papéis, como se não enxergasse nesta distinção uma problemática, e segue narrando de forma saudosa.

Ainda no início do romance, mais à frente, encontra-se um panorama da sociedade estadunidense antecessora, que originará o Estado totalitário de Gilead: 
Nós ansiávamos pelo futuro. Como foi que aprendemos isso, aquele talento pela insaciabilidade? Estava no ar; e ainda estava no ar, como uma reflexão posterior, enquanto tentávamos dormir, nos catres do exército que haviam sido dispostos em fileiras, espaçadas de modo que não pudéssemos conversar. Tínhamos cobertas, lençóis de flanela de algodão, como as de crianças, e cobertores padrão fabricados para o exército, dos antigos que ainda diziam U.S. Dobrávamos nossas roupas cuidadosamente e as colocávamos sobre os banquinhos aos pés das camas. As luzes eram diminuídas, mas não apagadas. Tia Sara e tia Elizabeth patrulhavam; tinham aguilhões elétricos de tocar gado suspensos por tiras de seus cintos de couro. (ATWOOD, 2006, p. 12)

Deste trecho é possível retirar dois elementos típicos do desenvolvimento do capitalismo no século XX: o consumismo-produção desenfreado, assim como o militarismo - não é de Gilead que se originarão nem o "talento para insaciabilidade" nem "cobertores padrão fabricados para o exército". São instituições fundadoras do capitalismo e afastam a ideia de que o golpe fictício de Estados Unidos para República de Gilead fosse uma fratura completa do que se assistia até então. Anotemos que essa continuidade das instituições Gilead-EUA escape à narradora, que frisa uma suposta oposição entre as duas sociedades, destacando com saudosismo suas liberdades individuais quando o mundo que conhecia era os Estados Unidos da América.

Para analisar o uso do tom nostálgico da narradora e o efeito que seu uso possui na estrutura do romance, é interessante realizar duas análises de contexto histórico da América do Norte: o contexto de crescimento no pós-guerra e o contexto de crise da década de 1980, quando o romance é publicado. No relato de Offred, ocorre uma confusão muito oportuna entre esses dois momentos históricos, com um efeito peculiar. $\mathrm{O}$ tom saudosista faz confundir ou mesmo igualar essas histórias, de modo a apagar a ideia de crise e desmentir qualquer possibilidade de existir uma continuidade ou similaridade entre Gilead-EUA.

Em uma breve digressão histórica, voltemos ao período de 1950 a 1973 (Hobsbawm, 2012), o qual ficou conhecido como os Anos Dourados ou les trente glorieuses, denominação carimbada por slogans dos anos de 1980 sobre a performance anterior dos países capitalistas desenvolvidos: são a era do televisor, do telefone, da batedeira, da sandália plástica, dos letreiros coloridos, do boom de megalópoles e da empresa offshore. O fordismo foi utilizado em novas indústrias, chegando até a alimentícia, com a fast-food, formando a base deste período de expansão pós-guerra que se prolonga até 1973. Segundo David Harvey, “os padrões de vida se elevaram, as tendências de crise foram contidas, a democracia de massa, preservada, e a ameaça de guerras intercapitalistas, tornada remota" (HARVEY, 2006, p. 125). Nestes Anos dourados, os países de 
Primeiro Mundo puderam assistir a um cenário com empregos e consumo em massa - a prosperidade e a privatização que daí advieram alargaram as fendas entre os diferentes setores de classe operária.

O romance, entretanto, está inserido em outro contexto histórico: o Desmoronamento. É uma época de acendimento dos faróis das correntes conservadoras, a exemplo das eleições de Margaret Thatcher e de Ronald Reagan. Assiste-se a um forte crescimento de movimentos religiosos de direita, como religious rights, e culturais, como a reunião da Moral majority nos Estados Unidos, em 1979, que tinha por objetivos tanto frear os "avanços da revolução sexual" das décadas antecedentes quanto combater as perigosas ideias vermelhas que "ventavam do leste" a todas as partes. No que se refere especificamente às conquistas de emancipação de movimentos de mulheres, é marcado pelo backlash, recrudescimento cultural que põe em xeque muitas conquistas anteriores. Visto por este ponto de vista, o panorama da década situa-se em horizonte imaginativo mais próximo a Gilead.

Hobsbawm adverte que a crise, que marcará este período, não será facilmente admitida como existente, pois a tentativa do discurso hegemônico à época era negar a possibilidade de existência de crises cíclicas do capitalismo:

A natureza global da crise não foi reconhecida e muito menos admitida nas regiões
não comunistas desenvolvidas, até depois que uma das partes do mundo - a URSS
e a Europa Oriental do "socialismo real" - desabou inteiramente. Mesmo assim,
durante muitos anos os problemas econômicos ainda eram "recessões". O tabu de
meio século sobre o uso do termo "depressão", lembrança da Era da Catástrofe, não
foi inteiramente rompido. (Hobsbawm, 2012, p. 394)

A tentativa de interpretação que se faz aqui seria apontar que, no romance, há a incorporação do tabu e não se admitiria a existência da Depressão nos anos de 1980.

Em muitas passagens, ocorre que não são os anos dourados que seriam saudosos à protagonista, pois deveriam ser as próprias décadas de crise. Aproveita-se o saudosismo para mirar outro alvo, que seria reforçar a hegemonia vigente - reforçar que não existiria uma crise global e desmesurada e não haveria alternativas viáveis ao modo de produção. Entretanto, em se tratando de literatura, emergem ideias pelas frestas do texto e, ao contrário do que possa a narradora sonhar, a República de Gilead acaba configurada como um aprofundamento da sociedade em que vivia. 
Veja-se um trecho crucial do romance, em que é narrado o golpe de estado, perfazendo a transição de Estados Unidos da América para a República de Gilead:

Foi depois da catástrofe, quando mataram a tiros o presidente e metralharam o Congresso, e o Exército declarou estado de emergência. Na época, atribuíram a culpa aos fanáticos islâmicos.

Mantenham a calma, diziam na televisão. Tudo está sob controle.

Fiquei atordoada. Todo mundo ficou, sei disso. Era difícil de acreditar. O governo inteiro massacrado daquela maneira. Como conseguiram entrar, como isso aconteceu?

Foi então que suspenderam a Constituição. Disseram que seria temporário. Não houve sequer um tumulto nas ruas. As pessoas ficavam em casa à noite, assistindo à televisão, em busca de alguma direção. Não havia mais um inimigo que se pudesse identificar. (...).

As coisas continuaram naquele estado de animação suspensa durante semanas, embora algumas de fato tenham acontecido. Os jornais foram censurados e alguns foram fechados, por motivos de segurança, disseram. As barreiras nas estradas começaram a aparecer, e Identipasses. Todo mundo aprovava isso, uma vez que era óbvio que não se podia ser cuidadoso demais. Eles diziam que novas eleições seriam realizadas, mas que levaria algum tempo para prepará-las. A coisa certa a fazer, diziam, era continuar como de costume. (ATWOOD, 2006, p. 210)

No trecho, há um elemento de conteúdo que fica ressaltado: a complacência da grande maioria da população diante das mudanças bruscas. Não se entende com clareza qual foi a catástrofe. Embora reste claro que o estado de exceção se estabelece por uma medida de segurança do próprio governo. A partir dessa medida de segurança estadunidense é que a República Gilead se ergue, ou seja, sua gestação tem a paternidade bem definida: os Estados Unidos da América dos anos de 1980. Parece que o adágio "tudo que é sólido se desmancha no ar" ecoa certeiro: todo um sistema que parecia ser duradouro - o das garantias legais e humanitárias, assim como as garantias financeiras - é dissolvido em pó num átimo, com a emergência de um estado totalitário capitalista.

Dessa maneira, embora a narradora se esforce para se refugiar em lembranças saudosas do passado, essas recordações não são os “verdadeiros anos dourados” de 1950 e 1960 aos quais ela assistiu, e sim as décadas de crise dos anos de 1980. Ou seja, o tom nostálgico que estrutura a narrativa reforçaria "o tabu do desmoronamento".

Inclusive, é notável que, na narrativa de Atwood, o princípio pelo qual a produção seria erguida se mantém firme: a lógica cultural do capitalismo não se altera nessa distopia. Mantém-se 
os privilégios de classe, a própria produção de mercadorias e a economia de guerra. $\mathrm{O}$ "talento para insaciabilidade" e os "cobertores fabricados para o exército" não simples coincidência do primeiro capítulo do romance.

Nas palavras oportunas de Jameson, o relato de Offred estaria situado para além do tempo histórico real. É como se a abordagem do então presente (anos 1980), traduzida pelo simulacro imaginado pela Aia de um passado estereotipado, emprestasse à realidade um encanto e uma distância dignas miragens - o passado seria um oásis de calmaria, mas, na verdade, configuraria o deserto do real:

(...) essa mesma modalidade estética hipnótica emerge como a elaboração de um sintoma do esmaecimento de nossa historicidade, da possibilidade vivenciada de experimentar a histórica ativamente. (JAMESON, 2006a, 148)

Essa postura imaginativa da nostalgia por um passado em que a historicidade foi esmaecida segue o pensamento hegemônico dos anos de 1980, em que se age como vítimas de situações históricas, situações às quais se assiste sem possibilidade de mudanças ou questionamentos para além do que existe: a resignação ao que conhecemos, a aceitação final de que o capitalismo pós-industrial não vai tão mal assim. Ao final da leitura do romance, parece que o que nos cerca é fantasticamente bonito e livre - folhear revistas femininas, a possibilidade de todos fazerem compras - a moral do romance seria algo como "dê graças a Deus pelo que você tem".

\subsection{A resignação como princípio de composição}

O ponto de contato entre as duas partes do romance - a existência da aia Offred e de seu relato ( $O$ conto da aia propriamente dito), parece providenciar, por intermédio da construção das características da narradora-personagem, um princípio de composição: a resignação ao que conhecemos hoje. Seu tom lamurioso, resume como uma bandeira: "Nenhuma esperança. Sei onde estou, e quem sou, e que dia é hoje" (ATWOOD, 2006, p. 135).

Esse princípio de composição age de maneira diferente nas duas partes do romance. Quando o narrador Pieixoto, inoportuno e sem credibilidade, capaz de irritar a mais branda militante feminista, acaba por confessar que organizou a seu bel-prazer a narração de trechos de histórias de uma sobrevivente, dá um golpe na imaginação de um planeta melhor, predizendo o futuro do mundo 
acadêmico que conhecemos hoje, que seguiria com suas piadinhas e privilégios, parecendo ser exatamente igual, cem anos depois. Importante ressaltar que a própria autora não enxerga esse possível futuro com esse pessimismo todo aqui descrito: ela se refere ao final do romance como algo otimista, pois gostaria de "mostrar que o terceiro Reich, o quarto Reich, o quinto Reich não duraram para sempre" (INGERSOLL, 2006, p. 116), ou seja, Atwood enxergaria esse "retorno ao mundo de hoje" como algo bastante feliz.

No que se refere à narrativa da aia, a resignação opera magistralmente no uso das formas bem familiares ao público feminino: a tradição de romances com heroínas sofridas, que sobrevivem a clausuras e privações, são elementos que evocam nestas tradições o tom desesperançado e a nostalgia de tempos melhores passados.

Qual seria, então, o referente captado e imitado nesta forma de prosa? (SCHWARZ, 2000, p. 35). Diferentemente de algumas análises que procuram fazer de HT um livro de brado feminista - "a feminist poetics" (DAVEY, 1984), aqui se procura trazer as contradições ideológicas do romance. O referente aponta para a emancipação das mulheres norte-americanas de classe média após a Segunda Guerra Mundial, mudanças que, contudo, não trouxeram um mundo mais justo, e sofrem um recrudescimento nos anos 1980 - sem frear a economia de guerra, sem impedir o acirramento das consequências do neocolonialismo ao Terceiro Mundo, sem terminar com a exploração no mundo do trabalho, sem se verificar a inserção de outras mulheres (que seguem excluídas por motivações relativas a raça, origem e classe), sem mesmo se verem livres das velhas pressões em novas roupagens sobre sua aparência física, dimensões corporais, responsabilidade para com a família e julgamentos morais.

A forma do romance denota, assim, implicações estruturais do quadro histórico dos anos 1980: são marcas da narrativa da Aia a frustração, a nostalgia, a hesitação diante da ação direta (a única que existe não nos é narrada até o final), o que é complementado pelo odioso narrador Peixoto, que sela com um possível "so sorry" qualquer aspiração feminista por uma mudança que seja plena e ampla para toda a sociedade.

Dessa maneira, o interesse no estudo de HT reside justamente em permitir a reflexão sobre a distopia e como se chegou a tal lugar o romance - em como a realidade social após a Guerra Fria torna-se constitutiva da própria forma literária, levando-se em conta a realidade social e as circunstâncias históricas que rodeiam o romance e suas funções (CANDIDO, 2006, p. 15). 
Em lugar de nos oferecer um mundo alternativo, Atwood apenas tem a nos oferecer a mesma nossa história. Em seu futuro paralelo, estão a economia de guerra norte-americana, o trabalho, o capital onipresente. Inclusive, a crueldade do relatório acadêmico do Professor Pieixoto faz páreo com programas de televisão - o relato transmitido sobre a vida da Aia parece ser absolutamente banal.

O argumento para se entender o motivo do estudo do livro é o perguntar-se: o princípio de alteridade situado especificamente na questão da opressão feminina em HT não seria insuficiente para se desenhar outra história? Não seria este romance exatamente um registro sobre a capitulação da busca por um sentido histórico e futuros históricos? Ao contrário do que se festeja nos elogios mais comuns ao romance, é na incapacidade de se imaginar outra história possível que reside o interesse crítico na obra. Que tempos são estes, em que a imaginação utópica é atrofiada e as possibilidades do inteiramente outro são impensáveis?

Se até mesmo o mais degradado tipo de cultura de massa apresenta uma dimensão utópica (SCHWARZ, 1994), o que resta é a crítica implícita sobre a ordem social em que este bestseller se originou - por exemplo, uma ideologia que tenta apagar a ideia de crises nos anos de 1980, incentivando a criação de uma atmosfera saudosista sobre o período anterior. A ideia da interpretação é detectar os traços da narrativa ininterrupta sobre a história maior ${ }^{15}$ a que estamos imersos, e trazer à superfície do texto "a realidade reprimida e oculta dessa história fundamental, em que a doutrina de um inconsciente político encontra sua função e sua necessidade" (JAMESON, 1999, p. 18).

\subsection{Alguns dados sobre a publicação}

Alguns dados sobre a publicação: The handmaid's tale figurou por 23 semanas na lista dos best-sellers ${ }^{16}$ do The New York Times. É obra prestigiada pelo mercado editorial de língua

15 “(...) uma que sempre terminou ou na reconstituição revolucionária da sociedade em geral ou na ruína comum das classes em oposição” (MARX, Karl e ENGELS, Friedrich. Manifesto Comunista).

16 Segundo a Enciclopédia Canadense (disponível em: http://www.thecanadianencyclopedia.com/index.cfm?PgNm=TCE\&Params=a1 ARTA0000712, acesso em: 3/11/2011) e muitas outras fontes, The Handmaid's Tale é considerado um best-seller no mercado editorial internacional, como outros da autora que, de acordo com a mesma Enciclopédia, domina as listas de prêmios e best-sellers da virada do século XXI (após o ano 2000, recebeu o Booker Prize por The Blind Assassin e depois teve grande sucesso editorial com Oryx and 
inglesa, recebedora do Governor General's ("for English language fiction") em 1985, Prêmio Arthur C. Clarke em 1987 (“for best science fiction") e menções no Prêmio Nébula, Brooker Prize (1986) e Prêmio Prometheus (1987). A Associação de Bibliotecas Americanas (American Library Association - ALA) considera o livro como um dos "100 most frequently challenged books of 1990-2000".

O livro é leitura obrigatória em escolas públicas e privadas em países de língua inglesa. Pelo seu caráter de “challenged book", esta adoção é periodicamente questionada por conselhos de pais, os quais se queixam de que o livro seria prejudicial aos filhos ${ }^{17}$ - acabou acusado de ser tanto anticristão quanto anti-islâmico. Também foi adaptado para o cinema, ${ }^{18}$ no ano de 1990 , com roteiro de Harold Pinter e direção de Volker Schlöndorff. Foi ainda transmitido em capítulos, em programa para a BBC Radio 4. Encontram-se, internet afora, referências de adaptações feitas para palco, incluindo uma ópera. ${ }^{19}$

Em bancos de artigos acadêmicos internacionais, é possível encontrar já considerável fortuna crítica referente a The handmaid's tale e, de forma mais esparsa, em livros que se dedicam à escritora. ${ }^{20}$ Segundo a CAPES, no Brasil, há 25 trabalhos de pós-graduação, ${ }^{21}$ entre dissertações e teses, que se dedicam à autora (com destaque à Universidade Federal de Minas Gerais), existindo um mestrado a respeito de The handmaid's tale de Marluce de Freitas Oliveira (OLIVEIRA, 2002).

Crake, outra distopia). Sua obra foi traduzida para mais de 35 idiomas, incluindo coreano, finlandês, islandês, japonês e português, sendo seus romances facilmente encontráveis nas livrarias megastore das capitais brasileiras.

${ }^{17}$ Segundo a reportagem: "Parent Robert Edwards lodged a formal complaint before the Christmas holidays, arguing the book is inappropriate because it contains foul language, anti-Christian overtones, violence and sexual degradation". (RUSHOWY, 2009)

18 Título: The Handmaid's Tale, lançamento em fevereiro de 1990, 109 minutes, Estados Unidos.

${ }^{19}$ Adaptação feita por Poul Ruders, lançada em Copenhagen, 2000. Foi apresentada na English National Opera em Londres, em 2003, e foi produzida também pela Companhia Canadense de Ópera em 2004 e 2005.

${ }^{20}$ Os principais seriam: COOKE, Nathalie. Margaret Atwood: A Critical Companion, Greenwood Press, Westport, CN: 2004; HOWELLS, Coral Ann. The Cambridge Companion to Margaret Atwood, Cambridge: Cambridge UP, 2006 e Margaret Atwood, Palgrave Macmillan, London: 2005; INGERSOLL, Earl G., Margaret Atwood: Conversations, Ontario Review Press, Princeton, New Jersey, 1990; McCCOMBS, Judit (org). Critical Essays on Margaret Atwood, G. K. Hall \& Co., Boston, 1988; NISCHIK, Reingard M (org). Margaret Atwood: Works and Impact. Toronto: House of Anansi Press, 2002 e Engendering Genre: The Works of Margaret Atwood, Ottawa: University of Ottawa Press, 2009. REYNOLDS, Margaret. Margaret Atwood: The Essential Guide to Contemporary Literature, London: Vintage, 2002. SULLIVAN, Rosemary. The Red Shoes: Margaret Atwood Starting Out, Toronto: HarperCollins, 1998, RUBBO, Michael, Margaret Atwood: Once in August. National Film Board of Canada, 1984. GORDON, Joel. Turning Pages: The Life and Literature of Margaret Atwood. V-Formation Productions, 2007.

${ }^{21}$ Portal de teses da CAPES consultado em novembro de 2011: http://capesdw.capes.gov.br. 
Sobre Margaret Atwood, encontramos ainda dois livros publicados no mercado editorial brasileiro, ${ }^{22}$ frutos de duas teses de doutorado, de Eliane Campello (2003) e Andrea Saad Hossne.

${ }^{22}$ Pesquisa feita no catálogo da Biblioteca Nacional por título em dezembro de 2014. 


\title{
Capítulo 4 - Feminismos e teorias de gênero nos dois romances
}

\begin{abstract}
Antes da Segunda Guerra, a sucessão de qualquer mulher à liderança de qualquer república, em quaisquer circunstâncias, teria sido encarada como politicamente impensável. (Hobsbawm, 2012, p. 307)
\end{abstract}

\subsection{Gender, questão comum aos dois romances}

O primeiro motivo mencionado para se colocar os dois romances em uma análise lado a lado é a proposta de se refletir melhor sobre a "questão de gênero": tanto LHD quanto HT trazem o tema muito desenvolvido, e este tema foi objeto de várias críticas que os livros receberam.

"Gênero", aqui, é utilizado referindo-se à categoria que faz a distinção social e sexual que, na segunda metade do século $X X$, ganha grande importância política ${ }^{23}$ por vários fatores históricos. O debate, inclusive, não parece esmorecer nos dias de hoje, o que justifica o interesse pelo presente trabalho.

Apenas uma observação sobre a redação: "gênero", em língua portuguesa, possui o par homófono e homógrafo que se refere à distinção entre as formas literárias - "gêneros literários". Dessa maneira, quando for para enfatizar ou explicitar os termos, serão utilizados os sinônimos em inglês: gender (distinção de caráter sexual e social) e genre (distinção de caráter literário).

O conceito de gênero, gender, seria aqui evocado tentando-se manter a complexidade e as tensões que o vocábulo por si só expressa, dado que é ressignificado continuamente pela teoria e pela militância feminista. Nas palavras de Donna Haraway, que se propôs a escrever um verbete para um dicionário marxista sobre a palavra-chave "gênero" e relata depois, no seu conhecido artigo Gênero para um dicionário marxista: a política sexual de uma palavra, toda a dificuldade e a complexidade da tarefa em redigir tal entrada:

O conceito feminista moderno de gênero não se encontra nos escritos de Marx e Engels, embora seus escritos e outras práticas, e as de outros da tradição marxista,

\footnotetext{
${ }^{23}$ Dois textos que sinteticamente trazem esta formulação seriam Hobsbawm, 2012, que no Capítulo 11 menciona a "Revolução cultural", e o Post-Scriptum que consta em ANDERSON, 1987, p. 102.
} 
tenham oferecido instrumentos importantes, assim como barreiras, para as teorizações posteriores sobre gênero. Apesar de importantes diferenças, todos os significados modernos de gênero se enraízam na observação de Simone de Beauvoir de que "não se nasce mulher" e nas condições sociais do pós-guerra que possibilitaram a construção das mulheres como um coletivo histórico, sujeito-emprocesso. Gênero é um conceito desenvolvido para contestar a naturalização da diferença sexual em múltiplas arenas de luta. A teoria e a prática feminista em torno de gênero buscam explicar e transformar sistemas históricos de diferença sexual nos quais "homens" e "mulheres" são socialmente constituídos e posicionados em relações de hierarquia e antagonismo. (HARAWAY, 2004, p.201-246)

Historicamente, o uso do termo "gênero" como diferença sexual é utilizado pela primeira vez em 1963 pelo psicanalista Robert Stoller, que se apropriou do termo como um conceito desenvolvido para contestar a naturalização da diferença sexual (HARAWAY, 2004, p. 211). Segundo Joan Scott (1986), o conceito de gênero teria surgido primeiramente entre as feministas norte-americanas, que preconizariam o dado social em detrimento do meramente biológico (SCOTT, [1995-2014]).

Com as seguidas reformulações teóricas, "gênero" passa a ser palavra que encerra em si uma disputa ideológica. Para exemplificar, Adriana Piscitelli, ao comentar mudanças históricas, ressalta que "o conceito de gênero foi abraçado com entusiasmo, uma vez que foi considerado um avanço significativo em relação às possibilidades analíticas oferecidas pela categoria 'mulher'” (PISCITELLI, 2002) - tal "avanço" e tal "entusiasmo" seriam rechaçados por outras linhas teóricas com mais afinidade com a crítica materialista, como por Roswitha Scholz ou por Nancy Hartsock (esta última, nos anos 1980, rejeitaria a terminologia gender "de modo a enfatizar as dimensões corporais das atividades das mulheres" [HARAWAY, 2004, p. 229]). ${ }^{24}$

A respeito dos romances, em LHD, a pergunta seria: como é imaginar uma utopia em que as diferenças de gênero não existem? Que desdobramentos sociais e políticos daí adviriam? Um processo inverso corre em HT: em lugar de se pensar como seria a ausência de marcação de gênero, a proposta é imaginar desigualdades de gênero mais profundas, em que as mulheres passem a ser determinadas segundo suas "mulheridades": donas de casa, esposas, procriadoras, prostitutas.

Dentro dos romances, essas modificações sociais originárias de seus contextos históricos aparecem representadas com grande frequência e projetadas dentro da lógica de cada narrativa.

\footnotetext{
${ }^{24}$ Para mais, HARTSOCK, Nancy. Money, sex and power: toward a feminist historical materialism. Nova Iorque: Longman, 1983.
} 
Mesmo em passagens que não possuem função estrutural nos romances, a questão de gênero emerge com bastante insistência.

Exemplificando com duas passagens em que o tema reverbera:

(1) Em LHD, o Enviado reflete sobre como as modificações na educação e na família poderiam ocorrer, caso a categoria de gênero fosse abolida, como é o caso dos gethenianos, com desdobramento inclusive na ideia de posse/responsabilidade sobre as crianças:

Aqui, o clã cuidava de suas próprias crianças; ninguém, e todo mundo, era responsável por elas. Eram irrequietas, correndo pelas colinas e praias ocultas pelas brumas. (...) $\mathrm{O}$ instituto materno ou paterno varia tanto em Gethen quanto em qualquer lugar. Não se pode generalizar. (...) O carinho pelas crianças pareceu-me profundo, efetivo e quase desprovido de possessividade. Somente nesta falta de possessividade ele, talvez, se diferencie do que chamamos de instituto "materno". Desconfio que a distinção entre instituto materno e paterno nem mereça ser mencionada; o instituto, o desejo de proteger e de favorecer, não é uma característica ligada ao sexo... (LE GUIN, 2005, p. 100)

(2) Em HT, a aia Offred e doméstica Cora conversam a respeito de um nascimento que ocorreu, ocorrência rara em Gilead. Enquanto Cora oferece a bandeja do jantar, faz perguntas sobre mexericos na vizinhança, embora já os conheça. A cena retrata formas de sociabilidade entre mulheres de classes sociais diferentes:

- É um bebê saudável? - pergunta Cora, enquanto está repousando a bandeja. Cora já deve saber, elas têm uma espécie de telégrafo de transmissão oral, de casa em casa, as notícias circulam; mas lhe dá mais prazer ouvir sobre o que aconteceu, como se minhas palavras venham a torná-lo mais real (ATWOOD, 2006, p. 166)

É possível afirmar que o tema gênero possui função estrutural em ambos os romances, perpassando todos os detalhes das obras, não sendo possível realizar uma análise em que não se estude a questão. Gênero é parte integrante da configuração da utopia e da distopia dos dois livros.

No mais, a ideia de colocar os romances em perspectiva com relação à categoria de gênero cresce em interesse, pois poderíamos vislumbrar propostas distintas: uma proposta de debate com mais afinidades a um programa anticapitalista, como ocorre no livro de Ursula Le Guin, assim como com maior afinidade a um programa feminista liberal, do qual seria representante o livro de Margaret Atwood. Ambos trazem em seus temas a discussão de causas feministas, entretanto, dentro de molduras ideológicas distintas. 


\subsection{Os impactos causados pela alteração do status da mulher}

O contexto histórico em que os romances são produzidos apresenta uma alteração profunda nas relações entre homens e mulheres, o que irá apresentar uma nova configuração cultural que será incorporada à lógica do capitalismo tardio, sendo o feminismo, na segunda metade do século XX, "um monumental fenômeno social que marcou uma época” (FRASER, 2009, p. 12).

Eric Hobsbawm, ao tratar das revoluções sociais e culturais de 1945 a 1990 (Hobsbawm, 2012, p. 307), confere grande destaque às mudanças provocadas pela alteração no status das mulheres, ocupando-se de forma extensa sobre o tema ao tratar do período.

O historiador menciona o impacto causado na classe operária norte-americana pela participação das mulheres casadas que trabalhavam fora do âmbito doméstico (representavam 14\% das mulheres em 1940, percentual que duplicou entre 1940 e 1970), a conquista do direito de voto feminino em muitos países nos anos 60 , a assunção de altos cargos políticos, muitas alterações legislativas (com destaque ao divórcio), as mudanças na forma de educar, no acesso ao ensino superior e na constituição do núcleo da família.

A respeito desse impacto e dos movimentos feministas, Perry Anderson, no Post Scriptum de In the Tracks of Historical Materialism, pondera que:

Nunca há nenhuma centralização global das estruturas de opressão feminina: e essa sua difusão enfraquece criticamente a possibilidade de insurgência unitária contra elas. Sem um foco centrípeto para a oposição, a solidariedade coletiva e a organização conjunta são sempre mais difíceis de se conseguir, mais difíceis de se manter. Nada disso significa, é claro, que seja impossível uma ação conjunta das mulheres pela sua liberação. Pelo contrário, pode-se dizer que, na década passada, tal ação conseguiu um grau de avanço maior do que qualquer luta operária no Ocidente. É verdade não apenas em termos de alterações legais ou atitudes culturais, mas também num sentido mais radical: a contestação do movimento feminista desde os anos 70 provavelmente fez mais do que qualquer outro fenômeno para forçar alguma consideração acerca da ideia de um futuro qualitativamente diverso numa sociedade burguesa em calma. (ANDERSON, 1987, p. 108) 


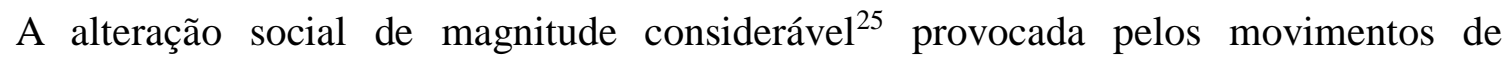
emancipação das mulheres não pode, contudo, ser associada a uma mudança de paradigma na forma de produção global capitalista. ${ }^{26}$ Há que se fazer a distinção crítica desde o início sobre este ponto segundo Perry Anderson:

Por universal que possa ser a causa da emancipação feminina, tão radical que, com ela, também os homens sejam libertados de suas condições existentes, ela é ainda insuficientemente operacional, como ação coletiva, real ou potencial, capaz de eliminar a economia e a política do capital. Para tal, é necessário uma força social dotada de alguma força estratégica. Apenas o "trabalhador coletivo" moderno, os trabalhadores que constituem os produtores imediatos de qualquer sociedade industrial possuem tal força - devido à sua "capacidade de classe" específica ou à posição estrutural no processo geral de maquinofatura capitalista, que só eles podem paralisar ou transformar, assim como só eles, em razão de sua coesão e massa potencial, podem fornecer os contingentes centrais do exército potencial da vontade e aspiração populares requeridos para tal confronto decisivo com o Estado burguês. Este exército certamente incluirá muitos trabalhadores que são mulheres e sempre mais, na medida em que a composição da força de trabalho continua a modificar o seu desequilíbrio sexual tradicional ao longo dos anos vindouros, assim como também incluíra feministas e socialistas, reunidos sob suas bandeiras próprias. Qualquer bloco insurgente capaz de desencadear uma transição para o socialismo será de composição plural e diversificada: mas só será isso, algo mais que um simples confronto dissidente, se possuir um centro de gravidade em torno daqueles que produzem diretamente a riqueza material em que se funda a sociedade do capital. (ANDERSON, 1987, p. 108)

\footnotetext{
${ }^{25}$ Alan Woods, ao lembrar momentos históricos em que a emancipação das mulheres e a luta pelo socialismo andavam próximos, inclusive cita um fato histórico que raramente é creditado às militantes mulheres - o estopim da Revolução Russa em 1917: “O papel das mulheres da classe trabalhadora foi visto na Rússia em fevereiro de 1917. O czar foi derrubado por uma revolução que começou no Dia Internacional da Mulher, quando as trabalhadoras de Petrogrado decidiram entrar em greve e protestar a despeito da recomendação dos bolcheviques locais que temiam a ocorrência de um massacre. Guiadas por seus instintos proletários de classe, elas puseram de lado todas as objeções e começaram a revolução. Veríamos muitos outros exemplos como esse no futuro". WOODS, Alan, Marxismo versus feminismo: a luta de classes e a emancipação da mulher. In: In defense of marxism. [S.1.], 18 de jul. 2001. Disponível em: http://www.marxist.com/marxismo-feminismo-emancipacao-mulher.htm. Acesso em: 14 de dezembro de 2014.

${ }^{26}$ Apenas para contextualizar, Perry Anderson trabalha o tema da emancipação das mulheres fazendo-se a seguinte pergunta: "qual é a relação entre o próprio socialismo, como prática, e o processo de emancipação humana em geral?". Disto decorre a pergunta e a problematização: "Qual a conexão entre a abolição da desigualdade sexual e o advento de uma sociedade sem classes? A dificuldade de qualquer simples identificação entre ambos não reside tanto na manutenção do privilégio masculino, em amplos setores da vida social, nas sociedades pós-revolucionárias atuais: pois essas ordens transitórias não são ainda, em larga medida, caracterizáveis como socialistas em termos marxistas enquanto ao mesmo tempo revelam claramente avanços em direção à igualdade, cada vez mais significativos e maiores do que nas sociedades pré-revolucionárias, recentemente industrializadas ou ainda agrárias, em estágios comparáveis de desenvolvimento econômico. O problema real para qualquer integração direta entre as perspectivas socialista e feminista deve ser buscado preferencialmente na natureza e na estrutura do capitalismo. Pois é perfeitamente claro que a dominação social dos homens sobre as mulheres antecede de muito o capitalismo - na verdade, ela é praticamente coextensiva à história, não apenas registrada, mas mesmo inferida, das espécies. Em nenhuma sociedade primitiva conhecida hoje está ausente a assimetria na sua distribuição de poder e posição entre os sexos. O nascente modo de produção capitalista herdou e retrabalhou essa desigualdade milenar, com sua miriade de opressões, ao mesmo tempo utilizando-a extensivamente e transformando-a profundamente." (ANDERSON, 1987).
} 
Mesmo com a alteração do status da mulher (inclusive restrita, muitas vezes, aos países ditos de maior desenvolvimento e às classes médias), a riqueza das sociedades ainda é dominada pelo modo de produção capitalista e segue apresentando a imensa acumulação de mercadorias. É neste contexto de rápidas alterações culturais e sociais, emergência de um novo tipo de vida social capitalismo tardio (JAMESON, 1985 27), e de manutenção dos pilares sociais capitalistas, como a propriedade privada e a produção de mercadorias, que permanecem imutáveis, que os dois livros foram produzidos. Segundo Jameson:

Podemos datar esta nova fase do capitalismo a partir do crescimento econômico do pós-guerra nos Estados Unidos, no final dos anos 40 e começo dos 50, ou então, na França, a partir da instituição da Quinta República, em 1958. A década de 60, sob muitos aspectos, é o período-chave de transição, um período em que a nova ordem internacional (neocolonialismo, a Revolução Verde, a informatização e a mídia eletrônica) não só se funda como, simultaneamente, se conturba e é abalada por suas próprias contradições internas e pela oposição externa. (1985)

No seio dos movimentos de emancipação das mulheres, são múltiplas e contraditórias as ideologias que envolvem o feminismo - desde o feminismo liberal, que fortalece a presença da mulher nos setores da produção, sem questioná-la ou a ela se opor, até divergentes manifestações do feminismo, que podem incorporar outros programas, como o socialista. Nas palavras de Perry Anderson,

(...) nem todo programa de emancipação humana coincide com o advento do socialismo, que atualmente não detém o monopólio do discurso utópico. (ANDERSON, 1987, p. 122)

Na sequência, serão apresentadas algumas narrativas sobre as teorias feministas do período que ficou conhecido por segunda onda, com as quais será possível oferecer materialidade a esse quadro de múltiplas teorias e contradições.

\subsection{A segunda onda: narrativas sobre as teorias feministas}

O que são as teorias feministas? A quantidade de temas e abordagens teóricas feministas é profusa no período considerado como a segunda onda do feminismo. Sobre a divisão cronológica das teorias feministas em ondas, basicamente há "a primeira onda, [que] vai do final do século XIX

${ }^{27}$ Este artigo foi posteriormente ampliado em Postmodernism or the Cultural Logic of Late Capitalism, New Left Review, n. ${ }^{\circ}$ 146, julho-agosto, 1984. 
ao fim da Segunda Guerra Mundial, quando o movimento experimenta um refluxo após as conquistas do direito ao voto em diversos países"; depois, a segunda onda, que é contabilizada do Armistício até os anos 1990, épocas de produção dos dois romances e de grande parte de sua recepção crítica (a denominada "terceira onda" oscilaria entre a década de 1990 e os dias de hoje, sendo as emergentes teorias de gênero e o suposto "pós-feminismo" o ponto de ruptura que inauguraria uma nova onda (GONÇALVES; PINTO, 2011).

Difícil é resumir tal profusão de temas e abordagens, pois exatamente no resumo do que consistiu essa passagem histórica é que se localizam muitos dos confrontos que irão constituir as teorias de gênero nos anos 1990 e 2000. É comum a utilização do seguinte resumo: em linhas gerais, após os anos 1980, a característica comum às teorias feministas e aos nascentes estudos de gênero, principalmente nos Estados Unidos e na Europa, seria a migração de discussões para o ambiente acadêmico, com maior profundidade e especialização de conceitos, com destaque à ampla frente teórica do estruturalismo e à sucessão pós-estruturalista.

Entretanto, Clare Hemmings fez uma investigação a respeito das narrativas que reconstituem as questões teóricas feministas e coloca que, embora haja uma profusão de autores, objetos, disciplinas e práticas, a história das décadas passadas é constantemente relatada como uma série de narrativas de progresso, perda e retomada que simplifica indevidamente um panorama que foi bem mais diversificado e polêmico do que se imagina:

A teoria feminista ocidental conta sua própria estória como uma narrativa em desenvolvimento, onde nos movemos de uma preocupação com unidade e semelhança, passando pela identidade e diversidade, em direção à diferença e à fragmentação. Tais mudanças são geralmente concebidas em correspondência com as décadas de 70, 80 e 90, respectivamente, e como um movimento partindo do pensamento feminista radical, socialista e liberal em direção a uma teoria pósmoderna do gênero. A mudança, que parte dos anos 70, ingênuos e essencialistas, para a crítica do feminismo negro e da "guerra dos sexos" dos anos 80 , e daí para os anos 90 da "diferença" e além, mapeia a estória como progresso para além das categorias e identidades falsamente delimitadas. (HEMMINGS, 2011, p. 3)

Segundo Hemmings, na "estória dominante da teoria feminista ocidental" (expressão que a autora utiliza ao se referir às teóricas do pós-estruturalismo anglófono), a ideia de superação teórica acaba por apagar traços desses debates tão pouco homogêneos e cheios de nuanças ideológicas. 
Hemmings sublinha as expressões dessas narrativas dominantes que propagandeiam um "progresso teórico" do pós-estruturalismo a partir do aprofundamento da categoria de gênero, supostamente obtido por intermédio das superações/reflexões a partir do "feminismo da diferença".

A expressão "feminismo da diferença" possui algumas acepções distintas dentro da trajetória norte-americana. Inclusive, o apagamento da distinção inicial para o que é tida hoje como a acepção predominante serve de fio narrativo para relatar estas tensões:

(a) A primeira acepção de "feminismo da diferença", que poderia ser situada historicamente na década de 1970, está relacionada às discussões sobre as distinções entre mulheres e homens, com explicações a respeito de matizes biológicas, culturais e outras (tais discussões, inclusive, são engendradas com o aparecimento das teóricas que defendiam o conceito de gênero, lembradas por Joan Scott (1986) - o conceito de gênero teria surgido primeiramente entre as feministas norte-americanas, que enfatizavam a "qualidade fundamentalmente social" das distinções baseadas no sexo, e o gênero "indicava um rejeição ao determinismo biológico implícito no uso de termos como "sexo" ou "diferença sexual” (SCOTT, [1995-2014]).

Um exemplo desta ideia de "diferença" seria a contribuição teórica de Gayle Rubin (1975a) a respeito do sistema sexo/gênero, reflexão que serve para diferenciar aspectos que estariam naturalizados, o sexo biológico e a diferenciação entre homens e mulheres:

O desenvolvimento desse sistema sexual [sistema sexo/gênero] tomou lugar no contexto das relações de gênero. Parte da ideologia moderna do sexo pressupõe que o apetite sexual é da província do homem e que a pureza é da mulher. Não é à toa que a pornografia e as perversões sejam consideradas como parte do domínio masculino (...). Para que possam participar das "perversões", as mulheres tiveram que superar limitações sérias de sua mobilidade social, recursos financeiros e liberdades sexuais. O gênero afeta a operação do sistema sexual e o sistema sexual já teve manifestações específicas do gênero. Mas apesar de o sexo e o gênero serem relacionados, não são a mesma coisa, e eles formam a base de duas arenas distintas da prática social. (Grifos nossos.) $)^{28}$

\footnotetext{
${ }^{28} \mathrm{O}$ adendo que segue à citação é: "essencial separar analiticamente o gênero da sexualidade para refletir com mais precisão a separação social existente. Isso vai contra o alicerce de muitos pensamentos feministas contemporâneos, que tratam a sexualidade como uma derivação do gênero". (RUBIN, 1975b). Tradução livre por Felipe Bruno Martins Fernandes, integrante do grupo de estudos da Profa. Dra. Miriam Pillar Grossi, coordenadora do Núcleo de Identidades de Gênero e Subjetividades - UFSC.
} 
(b) A segunda acepção de "feminismo da diferença" está relacionada às intervenções de feministas negras, homossexuais, imigrantes e de outros grupos, cujo discurso emerge para as discussões acadêmicas com mais relevo na década de 1980,

(...) argumentando que a opressão das mulheres não poderia ser entendida unicamente pelo viés da diferença de gênero, feministas negras, judias, lésbicas, operárias, do "Terceiro Mundo" e chicanas, entre outras (ou uma mistura de todas essas categorias), [que] demandaram atenção para as diferenças múltiplas entre as mulheres". (COSTA; ÁVILA, 2005)

Aqui poderíamos exemplificar ainda com a contribuição de bell hooks, com as obras Feminist Theory: From Margin to Center (1984) e Ain't I a Woman?: Black women and feminism (1981). No Brasil, o feminismo da diferença ocorre inicialmente em termos de militância, que ganha vigor após 1975, com os chamados "grupos de reflexão" ou de "autoconsciência", com a importante contribuição de Nzinga-Coletivo de Mulheres Negras (RJ), Criola (RJ) e Geledés (SP), entre outros. (DAMASCO; MAIO; MONTEIRO, 2012)

(c) A terceira acepção de "feminismo da diferença", que irá marcar a década de 1990, é colocada em pauta com a influência da différance francesa ${ }^{29}$ nos debates norte-americanos - esta última linha de estudo problematizaria a estrutura binária mulher/homem inicialmente colocada. Dessa maneira, a reinterpretação sobre a "diferença" acaba por contribuir para o que, mais tarde, foi denominado de "abordagem interseccional", mecanismo teórico de expansão do conceito de gênero para formulá-lo, segundo Judith Butler, "como parte do conjunto heterogêneo das relações móveis, variáveis e transformadoras do campo social”. (COSTA; ÁVILA, 2005)

Nesta terceira interpretação do sentido do que seriam as "diferenças", abre-se espaço para a colocação, finalmente do feminismo pós-estruturalista, capaz de absorver os discursos de afirmação das diferenças para devolvê-los com novas definições teóricas - nas palavras de Judith Butler, seria "somente através de existirmos no modo da tradução, constante tradução, que teremos alguma chance de produzir um entendimento multicultural das mulheres ou, de fato, da sociedade" (BUTLER, 2004).

Para sua construção teórica, Judith Butler coloca sob suspeita a noção universal de "patriarcado":

29 "Influência esta somente sentida nos anos 1980 a partir da publicação da coletânea New French Feminisms, organizada por Elaine MARKS e Isabel de COURTIVRON, 1979” (COSTA; ÁVILA, 2005). 
(...) uma universalidade categórica ou fictícia da estrutura de dominação, tida como responsável pela produção da experiência comum de subjugação das mulheres para inclusive apontar um caráter não-natural do sexo, este que seria tão discursivo e fruto de construções culturais tais como as que constroem gênero. ${ }^{30}$

Embora "narrativas dominantes" (para usar o termo de Clare Hemmings), como as de Judith Butler acima, tragam acréscimos fundamentais ao conceito de gênero - por exemplo, questionamento a respeito da binariedade, do falocentrismo e da heteronormatividade -, geralmente trazem uma ideia de "evolução" teórica, como se as discussões que afirmam as diferenças relativas a raça e classe social estivessem datadas ou até mesmo superadas.

Segundo Hemmings, as "narrativas dominantes" considerariam que o "pósestruturalismo imaginativamente desemboca na década seguinte [anos 1990], enquanto as críticas das mulheres de cor e das feministas do Terceiro Mundo são fixadas temporalmente" (HEMMINGS, 2011, p. 10) nos anos 1980, em um discurso que trabalha com o atributo de "evolução" no que se refere à desconstrução da categoria gênero - desta maneira, parafraseando Levi-Strauss, "a última finalidade dos estudos de gênero não seria constituir a mulher, mas dissolvêla".

\subsection{As teorias feministas e o mais novo espírito do capitalismo}

Nancy Fraser (FRASER, 2009), ao analisar as perturbadoras convergências das demandas do feminismo na segunda onda com a instauração do "novo espírito do capitalismo" (neoliberalismo), sublinha os benefícios da visão retrospectiva.

Ao escrever durante as décadas de 2000 e 2010 sobre os últimos quarenta anos, torna-se mais simples apontar as contradições e ambiguidades dos discursos feministas anteriores. Inclusive, reforça a importância de ampliar a nossa consciência histórica, principalmente em uma época na qual há uma grande facilidade de se rifar as lutas pela justiça de gênero por prêmios de consolação bem distantes de uma sociedade igualitária.

\footnotetext{
30 “Supondo por um momento a estabilidade do sexo binário, não decorre daí que a construção de 'homens' aplique-se exclusivamente a corpos masculinos, ou que o termo 'mulheres' interprete somente corpos femininos. Além disso, mesmo que os sexos pareçam não problematicamente binários em sua morfologia e constituição (o que será questionado), não há razão para supor que os gêneros também devam permanecer em número de dois. A hipótese de um sistema binário dos gêneros encerra implicitamente a necessidade de haver um sexo estável, expresso por um gênero estável, que é definido oposicional e hierarquicamente por meio da prática compulsória da heterossexualidade." (BUTLER, 2003)
} 
Aproveitando-se então dos benefícios da visão retrospectiva, traçam-se aqui alguns contrapontos a aspectos das teorias feministas dos anos da segunda onda que não apenas fortaleceram a hegemonia quanto contribuem, ainda hoje e de forma ativa, na construção de um novo modelo socioeconômico.

No contraponto então às "narrativas dominantes" (pós-estruturalistas), que tendem a apagar os questionamentos do "feminismo da diferença" pela suposta absorção/evolução da/para “desconstrução da categoria de gênero", é importante colocar as ideias de Roswitha Scholz. Esta crítica alemã reafirma, nos anos 2000, a necessidade de se problematizar, mais uma vez, a relação hierárquica de gênero ante as crises estruturais dos anos 1990, e coloca com insistência o patriarcado como um conceito central ("o patriarcado produtor de mercadorias").

Ao remontar as modulações teóricas dos anos 1980 e 1990, Scholz discorre sobre a mudança de paradigma dos estudos feministas às "teorias de gênero" - o paradigma novo seria então a construção/desconstrução da masculinidade e a feminilidade. Scholz repudia com veemência a abstração que este raciocínio pressupõe: o "esquecimento" sobre o fato de que o homem continua a ser estabelecido como o universal (SCHOLTZ, 2011), abstração que inclusive coloca como suspeitas as nomeações da relação assimétrica de gênero e o investimento político das construções teóricas anteriores, como as pesquisas entre as relações entre classe social e gênero.

Scholz aponta uma relação que não é exatamente a de superação entre os movimentos do "feminismo da diferença" e do "pós-estruturalismo". Apresenta o panorama crítico dos anos 1980, que parecia abrir um vasto leque de estudos e possibilidades - desde inserir na agenda uma “elaboração teórica (marxista) séria”, por exemplo, sobre as relações entre classe e gênero, até mesmo a elevação de gênero "de modo sociologista a princípio estrutural". Diante dessas vertentes críticas, a resposta hegemônica (pós-estruturalista) foi o apagamento da noção de diferença, na absorção das denúncias do feminismo da diferença sexual precisamente na "inversa (des)construção radical do gênero" (SCHOLZ, 2011).

Para contestar a resposta hegemônica, Scholz insere, no debate, um nível de abstração mais profundo sobre como agem as categorias da distinção sexual. Inclusive, esse tipo de recolocação teórica aparece muito nos estudos que confrontam o marxismo e o feminismo; por exemplo, Donna Haraway, em outro contexto, também aponta a "heterossexualidade inquestionável" em Marx e Engels, nas explicações sobre a posição subordinada das mulheres pela 
"categoria da divisão natural do trabalho" (HARAWAY, 2004). Scholz lembra que a teoria feminista, com relação à própria legitimação teórica, recorre à elaboração de conceitos androcêntricos - dessa forma, a partir do momento que se considera que o feminino estaria, desde o Iluminismo, relegado ao "outro da teoria", é necessário tematizá-lo como princípio social fundamental em um alto nível de abstração, de modo semelhante ao que se faz à teoria da dissociação e do valor. Apenas dessa maneira, a "verdade desta determinação não fíca para trás, mesmo se leva consigo a sua inverdade, por ser simultaneamente formulada como universalidade androcêntrica" (SCHOLZ, 2011).

Em seu artigo $O$ valor é um homem, ela explicita essa aproximação com a teoria da dissociação e do valor no seguinte parágrafo:

$O$ valor é o homem, não o homem como ser biológico, mas o homem como depositário histórico da objetivação valorativa. Foram quase exclusivamente os homens que se comportaram como autores e executores da socialização pelo valor. Eles puseram em movimento, embora sem o saber, mecanismos fetichistas que começaram a levar vida própria, cada vez mais independente, por trás de suas costas (e obviamente por trás das costas das mulheres). Como nesse processo a mulher foi posta como o antípoda objetivo do "trabalhador" abstrato - antípoda obrigado a lhe dar sustentação feminina, em posição oculta ou inferior -, a constituição valorativa do fetiche já é sexualmente assimétrica em sua própria base e assim permanecerá até cair por terra. Hoje parece chegada a hora em que este fim se aproxima historicamente, pois o homem deixou de ser literalmente "senhor" de seus próprios monstros e de si mesmo. O homem aparece como um aprendiz de feiticeiro, só que agora não há mais um mestre patriarcal capaz de consertar a situação. (SCHOLZ, 1996)

Mais do que insistir no patriarcado (que, na ironia de Butler, não gozaria mais da credibilidade que teve um dia), Scholz elege-o como princípio social fundamental, contudo, deslocado do que considera o "nível de abstração apropriado": o patriarcado produtor de mercadorias, compreendido como um processo levado à escala mundial. Sem aceitar a ideia de que assim cometeria um "essencialismo", radicaliza o questionamento da relação hierárquica de gênero e aponta o giro em falso das teorias que parecem se esgotar e não causam incômodo maior - repudia com veemência a reverência concedida aos empreendimentos acadêmicos do alegado (pós-) feminismo que “consegue, como quem não quer a coisa, 'estar presente' de certa maneira sem problemas, ofuscado pela 'grande luminosidade', ou seja, pela múltipla visibilidade das mulheres hoje, no sentido do baile de máscaras pós-moderno, que se limita a simular uma liberdade feminina (SCHOLZ, 2011). Em verdade, o sentido da pesquisa deveria caminhar para dar visibilidade ao problema fundamental da "diferença" como relação assimétrica de gênero. 
O pensamento teórico de Scholz seria ancorado nas estruturas patriarcais profundas da socialização da dissociação e do valor, "segundo as quais as mulheres devem ser responsáveis, em primeiro lugar, pelas atividades de reprodução, pelo amor, pela assistência, pelo cuidar e proteger na proximidade, devendo os homens, pelo contrário, ser responsáveis, em primeiro lugar, pelo trabalho abstrato, pela produção de valor, pela economia e pela política em geral". ${ }^{31}$

Diante das sucessivas últimas crises do capitalismo, coloca-se a mulher como gestora das crises - o que não trata de um apagamento das relações hierárquicas e sim de uma "relação neopatriarcal", um rearranjo de codificações sexuais. Para Roswitha Scholz, esses rearranjos podem ser descritos como um desenvolvimento real que somente é esclarecido tendo-se como "pano de fundo um patriarcado produtor de mercadorias entendido como processo à escala mundial" (SCHOLZ, 2011).

Nancy Fraser é outra voz muito importante na crítica feminista norte-americana que visa a recuperar a teorização feminista socialista, contrapondo-se às "narrativas dominantes" e sugerindo certo parentesco entre os impulsos utópicos feministas e a sedimentação do neoliberalismo.

Um de seus pontos de partida para perceber as contradições do movimento é sublinhar o compromisso das feministas para a transformação radical das estruturas profundas da totalidade social nos anos de 1970 a 1980. Embora não utilize o termo "patriarcado" para designar a totalidade social como Roswitha Scholtz faz, alegando que busca evitar um amálgama dos sistemas duais capitalismo/patriarcado, Fraser prefere denominá-lo como um sistema de uma forma historicamente específica:

(...) a sociedade capitalista organizada pelo Estado de forma androcêntrica, estruturada por três ordens inter-relacionadas de subordinação: (má) distribuição, (falta de) reconhecimento e (falta de) representação. (FRASER, 2009, p. 13)

Fraser trabalha com uma importante faceta das lutas e teorizações feministas, principalmente na segunda onda: a perturbadora convergência de seus ideais com aspectos fundadores do neoliberalismo. A teórica utiliza as ideias de Boltanski e Chiapello (2005), nas quais é colocado que

${ }^{31}$ Indo mais além: "A própria dissociação-valor que pode ser pensada como a mais elevada abstração. A teoria crítica da dissociação e do valor, no entanto, enquanto crítica imanente do universalismo androcêntrico, que ela defronta no seu próprio nível de abstração sem simplesmente o reproduzir, está obrigada a 'pensar contra si mesma' neste sentido aconteça o que acontecer, para poder ser ela própria e assim ir além de si mesma em mediação dialética negativa" (SCHOLZ, 2011). 
(...) o capitalismo se refaz periodicamente em momentos de ruptura histórica, em parte recuperando as tendências de crítica dirigidas contra ele. Em tais momentos, elementos de crítica anticapitalista são ressignificados para legitimar uma forma nova e emergente de capitalismo, que assim se torna dotada da mais alta significação moral necessária para motivar novas gerações a arcar com o trabalho inerentemente sem sentido de acumulação infinita. (FRASER, 2009, p. 13)

A hipótese central de Fraser é que houve um abandono da crítica à economia política em um momento em que todas as forças de militância e pensamento se concentravam na crítica cultural, além de ocorrer uma apropriação das utopias de gênero na constituição desta nova lógica mundial.

Em épocas de ascensão do neoliberalismo, em que se assiste ao desmonte do estado de bem-estar social, fortalecimento de mecanismos de controle do mercado pelo mercado, privatizações, desregulamentações e aumento da responsabilidade pessoal, tempos em que as instituições estatais são enfraquecidas em comparação à escalada privatista, as demandas que foram construídas pelo movimento feminista até então - como autonomia, horizontalidade e diminuição da autoridade, são reincorporadas às práticas neoliberais intensificando a valorização do trabalho assalariado. O ponto chave de afinidade dos dois programas - feminista e neoliberal - encontrar-seia na crítica à autoridade tradicional. No feminista, sair da sujeição masculina. No neoliberal, retirar obstáculos à expansão capitalista.

Assim, por exemplo, na classe média, postulados antigos como a igualdade salarial entre mulheres e homens ganham maior visibilidade, até discutidos na mídia tradicional, pois são traduzidos na necessidade da submissão ao trabalho assalariado e a outras formas de subordinação mais flexíveis ao capital, o que se traduz em degradação das condições de trabalho e maior vulnerabilidade social:

Afinal de contas, este capitalismo preferia confrontar mais as reivindicações para o reconhecimento e não as reivindicações para a redistribuição, na medida em que constrói um novo regime de acumulação sob a pedra angular do trabalho assalariado das mulheres, e busca separar os mercados de uma regulamentação social a fim de operar ainda mais livremente em uma escala global. (FRASER, 2009 , p. 28)

Outros fatores mencionados por Fraser foram a dificuldade de confrontar o sexismo dentro da Esquerda e uma crítica feminista que surge contra as instituições e as formas de participação política. Aqui são consideradas as feministas socialistas, as de movimentos de negritude, de grupos LGBT e as anti-imperialistas (para o feminismo liberal não houve este 
confronto, pois simplesmente se apartaram e atuaram de forma independente), o que fez grande parte da produção teórica e militante recair na crítica das instituições - "interpretando que a cultura de instituições de larga escala e hierarquizada expressava a masculinidade modernizada do estrato profissional-gerencial do capitalismo organizado pelo Estado" (FRASER, 2009).

Esta crítica às instituições desenvolveu práticas organizacionais novas, com valores democráticos, participativos, visando ao empoderamento de cidadãos e sujeitos. Aqui as ações apareciam menos com vistas a desmontar as instituições e mais para transformá-las "em agências que promoveriam, e de fato expressariam, justiça de gênero". O fortalecimento do neoliberalismo acaba em uma confluência interessante para essa guinada política das instituições: a difusão de novas práticas de gestão na própria esfera da produção, práticas tributárias da agenda feminista como autonomia, horizontalidade, gosto pela criatividade individual, autoaperfeiçoamento. Tais práticas acabam por revestir a submissão ao trabalho com um novo verniz utópico, que, mais uma vez na história, confere sentido ao que é vazio (qualquer semelhança com o que o Google propagandeia a seus trabalhadores não é coincidência).

Acrescente-se ao raciocínio de Fraser que a mera existência dessas instituições, ironicamente bastante enfraquecidas em tempos neoliberais, gera uma aparência de justiça social e de avanços nas equidades de gênero, quando antes eram impensáveis. A simples existência deste aparato (para exemplificar, seriam aqui consideradas comissões estatais, sindicatos, comissões que integram partidos políticos, ONGs e a própria academia), hoje absorve e direciona os estudos críticos e a militância, dado que constroem ações e asseguram, de certa maneira, justiça de gênero de forma efetiva. De forma dialética, é a sua existência, inclusive, que impede uma reelaboração feminista independente e menos tributária do modelo capitalista atual, dado que essas instituições absorvem demandas e as formatam dentro das soluções e práticas institucionais já consolidadas.

É a partir desse panorama conturbado por muitas correntes teóricas, disputas ideológicas e contradições sobre o que seriam as conquistas do feminismo que os dois romances são analisados. Acredita-se que uma visão crítica interessante seria a que admite que muitas das mudanças culturais impulsionadas pelo feminismo, principalmente na segunda onda, serviram para a formação social hegemônica no pós-guerra. Admitir a capitulação é poder recapitular e apresentar, mais uma vez, a utopia feminista: a luta por uma sociedade justa e igualitária. 


\subsection{Que ele era uma mulher, assim como era um homem}

Ursula Le Guin produz o romance The Left Hand of Darkness no final dos anos 1960 (publica em 1969), em uma época privilegiada de conformação de alguns debates feministas da segunda onda, com grande ebulição de temas e embates ideológicos. No contexto histórico, era possível assistir a articulações de movimentos feministas com outros movimentos sociais, eram tempos em que a militância tinha maior predomínio do que a especialização teórica, apresentando grande força de mobilização em espaços públicos, com uma agenda ampla de assuntos. Nesta época, revoluções culturais pareciam prementes, em um movimento além dos horizontes do modo capitalista de produção e não, como ocorrerá nas décadas a seguir, quando se observa um avanço em questões culturais, mas um retrocesso na "crítica à economia política", para seguir com as teorizações de Fraser.

Para usar a terminologia da própria Le Guin, em sua introdução às edições posteriores de LHD (LE GUIN, 2005, p. 5-6), o objetivo do "experimento mental" expresso no livro seria extrapolar a realidade existente para descrever justamente o mundo que nos rodeia. Em seu experimento mental, a autora propõe que imaginemos como seria nossa sociedade sem a distinção de gênero, provavelmente para apontar como somos dela dependentes e como papéis sexuais são imbricados em nossa economia, cultura e política em um grau muito profundo.

Citando um trecho do romance, em que se evidencia a visão do Enviado sobre Estraven, um dos habitantes de Gethen:

Vi, então, novamente, e de uma vez por todas, o que sempre tivera medo de ver e vinha fingindo não ver nele: que ele era uma mulher, assim como era um homem. (LE GUIN, 2005, p. 240)

Le Guin, então, na sua criação do planeta Gethen, incorpora algumas das preocupações teóricas, típicas das correntes feministas à época, quando ainda se elaborava o conceito de gênero. Ao postular uma utopia em que "não há mais categoria de gênero", a autora parte da configuração do sexo biológico, igualando os dois conceitos: se os corpos são idênticos, não haveria mais a distinção entre os sexos, logo não haveria distinção entre gênero.

A dependência da constituição biológica para a marcação de gênero prevaleceu nessa época. Claudia de Lima Costa coloca que, neste início da segunda onda do feminismo, as principais correntes teóricas trabalhavam com "gênero" como uma variável binária, sendo admitido o binômio 
homem/mulher, sem maiores nuanças, e sua consideração dependia fortemente das relações biológicas (COSTA, 1994). Essa concepção inicial será criticada por diversas correntes que tiveram prevalência acadêmica. Um exemplo seriam os estudos de Gayle Rubin, que não considera a sexualidade como derivação obrigatória do gênero e, sim, como um sistema mais complexo, em que sexo e gênero não apareceriam em um amálgama:

O "gênero" afeta a operação do sistema sexual e o sistema sexual já teve manifestações específicas do gênero. Mas, apesar de o sexo e o gênero serem relacionados, não são a mesma coisa, e eles formam a base de duas arenas distintas da prática social essencial separar analiticamente o gênero da sexualidade para refletir com mais precisão a separação social existente. Isso vai contra o alicerce de muitos pensamentos feministas contemporâneos, que tratam a sexualidade como uma derivação do gênero. (RUBIN, 1975b)

Entretanto, lançando mão das questões como apresentadas à época, no romance, a autora oferece prevalência ao dado biológico. Dessa maneira, há explicações detalhadas sobre o ciclo reprodutivo dos gethenianos. A princípio, no período do somer, são andróginos. Quando entram no período do cio, denominado kemmer, podem entrar em um estado de excitação e adquirirão características femininas ou masculinas. Dessa maneira, qualquer getheniano pode engravidar, pois possui o aparelho reprodutor para isso:

Disseram que o rei estava muito velho para dar à luz e fizeram comentários hilariantes e obscenos sobre o assunto. (LE GUIN, 2005, p. 101)

Interessante observar que os gethenianos transformam-se em pares heterossexuais e não há menção digna à possibilidade de homossexualidade, transexualidade ou mesmo de se transformarem um gênero terceiro ou quarto. Há uma dependência absoluta à ideia binária de gênero (homem/mulher), que termina por sugerir a visão do sexo voltado à reprodução da espécie, aspecto que tolhe consideravelmente a imaginação utópica.

Citando-se alguns detalhes sobre a constituição biológica dos gethenianos:

O ciclo sexual dura, em média, de 26 a 28 dias (eles tendem a falar em 26 dias, aproximando-o do ciclo lunar). Durante 21 ou 22 dias, o indivíduo é somer, sexualmente inativo, latente. Por volta do $18^{\circ}$ dia, mudanças hormonais são desencadeadas pelo controle pituitário e, no $22^{\circ}$ ou $23^{\circ}$ dia, o indivíduo entra no kemmer, o cio. Nesta primeira fase do kemmer (secher, em karhideano), ele permanece completamente andrógino. O gênero ou a potência não são atingidos em isolamento. Um getheniano, na primeira fase do kemmer, se deixado sozinho ou na companhia de outros que não estão no kemmer, permanece incapaz de coito. Contudo, o impulso sexual é tremendamente forte nessa fase, dominando a personalidade, submetendo todos os demais impulsos à sua vontade. Quando o 
indivíduo encontra um parceiro no kemmer, a secreção hormonal recebe novo estímulo (principalmente pelo toque... Secreção? Cheiro?), até que, num dos parceiros, ocorra a dominância hormonal masculina ou feminina". (LE GUIN, 2005, p. 92) (grifos nossos para se ressaltar a equivalência dos termos "gênero" $e$ potência, que são utilizados indistintamente no romance).

O livro foi lido com bastante atenção após sua publicação e foi alvo de duras críticas a respeito da presença da heteronomatividade em um planeta em que, a princípio, não haveria distinção sexual. Esta polêmica resultou em três textos críticos da própria Le Guin em defesa de sua obra: Re: Lost Opportunities (1972) ${ }^{32}$, Is Gender Necessary? (1979) e depois Is Gender Necessary? Redux (1989).

A crítica que mais ficou famosa e inaugurou este debate foi o artigo Lost Opportunities de Stanislaw Lem (1971), conhecido escritor de ficção científica, autor de Solaris. Criticamente, aponta muitas incongruências no texto de Le Guin: embora considere a importância da mensagem, sublinha a ausência de um desenvolvimento mais profundo das decorrências em não se ter a distinção de gênero em uma sociedade. Lem elogia as descrições de natureza antropológica, mas diz que os "entendimentos de ordem psicológica, por outro lado, são apenas suficientes e, algumas vezes, mesmo insuficientes" (LEM, 1971, p. 22) - Lem faz a acusação que as constantes mudanças de sexo nos gethinianos deveriam afetá-los, considerando relacionamentos e identidade pessoal. $\mathrm{Na}$ questão da heteronormatividade, especificamente, para Lem a representação da ambivalência é falha, tendendo ao puramente masculino:

(...) because Karhider garments, manners of speech, mores and behaviour, are masculine. In the social realm, the male element has remained victorious over the female (LEM, 1971, p. 24).

Em outras palavras, aproveitando-se das teorizações feministas, em LHD, a ausência da marcação de gênero estabeleceria assim o masculino. Como seria de se imaginar o "termo neutro"? Judith Butler fará uma observação pertinente, em sua proposta de desconstruir o padrão binário: “oposto de masculinidade [que] não seja necessariamente a feminilidade” (PRINS, MEIJER, 2002).

Em sua primeira resposta às observações de Stanislaw Lem, Ursula Le Guin convida Lem ou qualquer outra pessoa a apontar uma única passagem em que Estraven faz ou fala algo que apenas um homem poderia falar. Le Guin inclusive critica o condicionamento cultural que insiste

\footnotetext{
${ }^{32} \mathrm{Um}$ artigo breve e muito interessante a esse respeito, que inclusive serviu de guia para entender o vaivém crítico, é o post de TILLACK, Tim, The critical reception of Ursula K. Le Guin's "Left Hand of Darkness". Disponível em: http://knowledgeeater.blogspot.com.br/2011_10_01_archive.html. Acesso em: 14 de dez. 2014.
} 
em atribuir masculinidade a Estraven e a outros gethenianos apenas pelo motivo de ser pouco crível, em nossa sociedade, acreditar que mulheres poderiam cruzar perigosamente um deserto de gelo ou ser primeiros-ministros (o que nos remete à epígrafe de Hobsbawm para este capítulo: "antes da Segunda Guerra a sucessão de qualquer mulher à liderança de qualquer república, em quaisquer circunstâncias, teria sido encarada como politicamente impensável"). Susan Willis, em outro contexto, observaria: "Pela simples razão de serem dominantes, os homens não necessitam proclamar-se como sujeitos com um determinado gênero" (WILLIS, 1997, p. 91).

Os questionamentos sobre a obra avançam. Joanna Russ (1972), crítica e autora de ficção científica de cunho feminista, cuja principal obra é The female man, aponta o uso dos pronomes masculinos na referência a Estraven e também sugere que as instituições culturais e a cultura em geral poderiam ser diversas, na ausência do padrão de diferenciação sexual. Uma das observações mais pertinentes desta crítica: e a formação familiar? E os papéis de gênero na condução da educação das crianças?

Alguns anos depois, em 1979, Le Guin publica Is Gender Necessary? e, em 1989, Is Gender Necessary? Redux, admitindo a questão dos pronomes, que seria enfrentada de outras maneiras, tanto por escritores, quanto militantes - por exemplo, na escrita inclusiva do português, terminações escritas com " $\mathrm{x}$ ” em lugar da desinência de gênero dos substantivos e adjetivos (ex.: garotx bonitx). A capitulação da autora é útil para se refletir, depois de tudo, a respeito das limitações em se conseguir imaginar uma utopia em que não haja mais uma distinção que envolva gênero.

Finalmente, é interessante pensar a respeito de interpretações de LHD possíveis à luz de teorias contemporâneas, dado que ocorrem, no romance, algumas antecipações ao que é denominado, hoje, "terceira onda do feminismo", após os anos de 1990. Uma das tendências teóricas do atual momento histórico seria concentrar os questionamentos na alteridade - em lugar de se enfocar o estudo nas mulheres, amplia-se a visão para o estudo das relações de gênero, abrindo espaços para outras militâncias, como a transexualidade, e afastar as noções de binariedade, entre outras demandas. No caso, algumas teóricas da terceira onda irão retirar, inclusive, a categoria mulher como sujeito e objeto do conhecimento feminista (HEMMINGS, 2009): 
as estreitas relações entre teoria e política-militância feminista - dos Estudos de Gênero, cujos pressupostos abarcam a compreensão do gênero enquanto categoria sempre relacional. (KOLLER; NARVAZ, 2006)

Para contextualizar essas ideias, é relevante perceber que muitas são tributárias do feminismo pós-estruturalista, responsável por absorver e redirecionar os discursos de afirmação de desigualdades que envolvem raça, classe social e países com economias periféricas dentro das elaborações feministas mais liberais (ou dentro de uma roupagem mais afinada com o novo espírito do capitalismo), dado que nem sempre é possível dizer que há uma "evolução" no que se refere à desconstrução da categoria "gênero", pois pode ocorrer um apagamento indevido de questões sociais.

O que aproximaria o romance destas tendências teóricas seria que Le Guin parece utilizar-se do mecanismo criativo de dissolução da categoria mulher quando desenha seres que podem apresentar transformações biológicas para ambas as configurações fisiológicas da binária de sexo (/homem/ e /mulher/), não se colocando, a princípio, nenhuma como a única passível de diferenciação. Assim, uma das soluções de Le Guin para desconstruir a distinção de gênero seria simplesmente negá-la, ou seja, retirar a marcação. Veja-se um trecho do romance no qual a observadora e pioneira Ong Tot Oppong faz anotações a respeito dos gethenianos:

A estrutura de suas sociedades, a administração de sua indústria, agricultura, comércio, o tamanho de suas instalações, o assunto de suas histórias, tudo é modelado para se ajustar ao ciclo somer kemmer. Todos tiram férias uma vez ao mês; ninguém, qualquer que seja sua posição, é compelido ou obrigado a trabalhar quando está no kemmer. Ninguém é barrado na casa de kemmer, por mais pobre ou estranho que seja. Tudo abre caminho diante do tormento recorrente e do regozijo da paixão.

É fácil entendermos isto. O que é difícil de entender é que, oitenta por cento do tempo, essas pessoas não têm qualquer tipo de motivação sexual.

Existe espaço para o sexo, espaço de sobra; mas um espaço, por assim dizer, à parte. A sociedade de Gethen, em seu funcionamento diário e em sua continuidade, é assexuada. (LE GUIN, 2005, p. 94)

No trecho citado, é perceptível a configuração de uma sociedade que não se deixaria levar pelas distinções de ordem sexual, como se a diferenciação de gênero fosse passível de apagamento. Le Guin muitas vezes consegue o grande feito de misturar comportamentos e experiências de maneira que haja uma suspensão dessas diferenciações. Em mais um exemplo, 
segue um excerto em que o Enviado é recebido em Orgoreyn, nação burocrática de Gethen, por um alto político dos comensais, Shusgis, muito preocupado em garantir o conforto de seu hóspede:

- Sei como é - disse ele. - Quando eu estava grávido, não conseguia me esquentar - meus pés ficavam um gelo, fiquei sentado perto da lareira durante todo aquele inverno. Já faz tempo, claro, mas eu me lembro! - Os gethenianos tendem a ter filhos ainda jovens; a maioria usa contraceptivos depois dos vinte e quatro anos, mais ou menos, e deixa de ser fértil, na fase feminina, por volta dos quarenta anos. Shusgis tinha cinquenta e poucos anos, daí seu "já faz tempo, claro!", e certamente era difícil imaginá-lo como uma jovem mãe. Era um político vigoroso, astuto e jovial, cujos atos de gentileza serviam ao seu interesse e cujo interesse era ele próprio. (LE GUIN, 2005, p. 115)

Com a extirpação da ideia de gênero, a personagem Shusgis consegue ter dualidades além-gênero - ser maternal e acolhedora no âmbito privado (característica "feminina"), ser política implacável no âmbito público (característica "masculina”), ao mesmo tempo em que pode conceber filhos, em uma sugestão clara de que não existiria o patriarcado, embora existam claramente poder e classes sociais:

Testamentos particulares não são legais: quando um homem morre, deixa sua fortuna para o Estado. Todos começam iguais.

Mas, obviamente, não continuam assim. Shusgis era rico e generoso com suas posses. (LE GUIN, 2005, p. 115)

Dessa forma, em alguns trechos do romance, logram-se configurar "distinções sociais além-gênero" e sugerir formas de discriminação sem relações necessárias com a categoria /mulher/ ou patriarcado, em um acerto interessante da autora tanto à luz de discussões mais recentes quanto em não ignorar outros processos de exclusões sociais.

Entretanto, essa coerência criativa não se mantém por toda a obra, conforme ficou apontado nas críticas de Lem e Russ citadas anteriormente: no jantar que se segue a esse trecho, a "masculinidade" de Shusgis é visível, quando assume o papel público de homem da política, retornando o "fantasma da divisão da humanidade em gêneros" a assombrar a criação literária.

Em resumo: se, por um lado, o romance abre caminho para que se pense não mais em mulher como categoria central de análise (algo que, no momento contemporâneo, possui prevalência teórica e, ao mesmo tempo, no romance é incorporado de maneira a ignorar outras formas de exclusão social, como classes sociais), por outro lado, são pertinentes as críticas que apontam que, no processo criativo da autora, estejam acentuadas as diferenças biológicas binárias 
entre os sexos e os papéis típicos de um sistema heteronormativo. Sem dúvida, há uma dependência grande de aspectos físiológicos e biológicos na configuração utópica, além da idealização na binariedade (e não uma divisão entre três, quatro ou múltiplos gêneros). No saldo final, parece que são apresentados mais limites para se configurar uma utopia coerente no que diz respeito a gênero do que o romance conseguiria dar conta.

Este "fracasso" da autora caminha no sentido da pergunta "Seria possível conceber uma utopia no que diz respeito a gênero?”. Seria possível conceber a linguagem e a representação completamente fora do sistema heteronormativo? Transcender um aspecto da divisão entre seres humanos mais remoto do que a formação das classes sociais?

\subsection{O conceito de shiftgrethor}

Um elemento de análise interessante no romance é o conceito alienígena shifgrethor. O Enviado não logra compreender exatamente o que seja o termo, que se refere a uma forma de distinção dos gethenianos, feita de maneira bastante complexa e com decorrências importantes para a vida prática no planeta.

A interpretação proposta aqui é a seguinte: assim como os gethenianos não compreendem o que seja uma divisão entre humanos baseada em gênero, o Enviado não compreende o que seja uma divisão baseada no critério de shiftgrethor.

Le Guin escreve o romance tanto a partir da visão do alien quanto do colonizador. Considerando que o Enviado representa a posição de colonizador de outros planetas, ao menos no que diz respeito a propagar a "iluminação" e as "benesses" do Ekumen, uma pergunta possível seria: Could the gethenien speak?, em uma paródia da indagação de Spivak (2010) (que não é de tradução imediata em português, segundo Sandra Almeida, pois reforçaria a dualidade do verbo modal can: “O subalterno como tal pode, de fato, falar?”). Como seria apresentar uma diferença, que, a princípio, seria inexistente ou proibitiva? Como traduzir as tensões colocadas pela presença do enviado Geny Ali em Gethen, planeta que insiste em chamar de Inverno? Como construir um narrador que corrobore a hipótese de que os gethenianos seriam um antigo experimento de laboratório de seu próprio povo e implantar um critério novo (e aos gethenianos ilógico ou mesmo pervertido) de distinção entre as pessoas, ou seja, o gênero? 
Ursula Le Guin utiliza-se então do conceito de shifgrethor, que, no contexto da discussão de gênero no romance, poderia ser considerado um elemento que funcionaria como uma representação do olhar do alien a respeito da binária dos sexos.

O conceito fictício de shifgrethor, válido para os habitantes de Karhide, é uma espécie de código de honra ${ }^{33}$ ou senso de respeito, do qual decorrem intrincados códigos de conduta. É interessante perceber que, mais de uma vez, o narrador principal, estrangeiro à cultura karhideana, não compreende bem as nuances do shifgrethor:

Durante a pausa comecei a pensar que um alienígena inepto e indefeso não deveria exigir explicações do primeiro-ministro de um reino, sobretudo quando esse alienígena não compreende, e talvez jamais compreenda, as bases do poder e o funcionamento do governo do dito reino. Sem dúvida, era tudo uma questão de shiftgrethor - prestígio, aparência, posição, orgulho, o intraduzível e importantíssimo princípio de autoridade social em Karhide e em todas as civilizações de Gethen. E, se era este o caso, eu certamente não entenderia. (p.102)

Considerando que o romance trata da questão da ambissexualidade, mas a narra do ponto de vista de quem é /homem/ civilizador, o shifgrethor é o elemento que não pertence à lógica do colonizador. Marca a incompreensão de critérios que o narrador não alcança compreender, assim como os karhideanos não logram compreender a binária de gênero - ou não estão aptos a falar a esse respeito ou não são a isso incentivados, pois poderia soar como “perversão" em sua cultura.

Assim, a melhor maneira de representar a ausência da distinção entre sexos é utilizando um critério que também é estranho a leitores e narrador - um critério do alien, do outro.

Se, por um lado, o romance fracassa em conceber um padrão imaginativo além do heteronormativo - ratificando as críticas de Lem e Russ e autocrítica posterior de Le Guin -, por outro é feliz em imaginar outro critério, cuja lógica escapa à razão do principal narrador. A autora deixaria, então, o seu leitor em uma posição tão deslocada quanto o narrador ante os alienígenas, abrindo um espaço para que se imagine o que poderia ser a alteridade sem efetivamente descrevê-la ou delimitá-la.

Dessa maneira, o shifgrethor é uma maneira de, por intermédio da negatividade, representar a questão de gênero para os khahirdeanos, que não conhecem o conceito. Trata-se de um

33 "A sense of honor and respect that provides the Gethenians with a way to save face in a time of crisis" (McWHORTER, 1998). 
ponto que escapou da crítica que nos chegou ao conhecimento até então. Aqui se faz assim uma contribuição interpretativa aos estudos de LHD.

\subsection{HT, um romance recepcionado como feminista}

Desde 1969 (publicação de The Edible Woman e também de HT), Margaret Atwood foi recepcionada como escritora que defenderia "os direitos das mulheres" - embora a própria autora, na introdução ao livro em 1979, "se defenda" do rótulo dizendo-se "protofeminista". Muito da crítica sobre The Handmaid's Tale recai especificamente sobre o tema do feminismo e estudos de gênero, como o capítulo Second Wave Feminism as Anti-Utopia de Fiona Tolan, que escreve Margaret Atwood - Feminism and Criticism em 2007, e Engendering Genre: The Works of Margaret Atwood, de Reingard Nischik, de 2009.

Segundo Coral Ann Howells (1996, p. 18), o livro traria uma visão histórica sobre o movimento feminista norte-americano, desenhando o panorama desde como teria ocorrido a mudança dos clamores iniciais pela libertação feminina no pós-guerra até apresentando um feminismo mais teórico e com sutilezas políticas dos anos 1980 e 1990. A crítica ressalta que a análise de Atwood seria balizada então por parâmetros culturais, com padrões de interação social e suas consequências - assim como o feminismo contribui para alterações ideológicas além de seus círculos, também o próprio feminismo deveria ser transformado.

Assim como Le Guin, Margaret Atwood trabalha dentro do que foi convencionado se chamar de segunda onda do feminismo. Retomando as ideias de Donna Haraway, alguns dos temas da segunda onda giram "em torno dos 'determinismos biológicos' versus 'construcionismo social"” e "das 'biopolíticas' das diferenças de sexo/gênero [que] ocorrem no interior de campos discursivos pré-estruturados pelo paradigma de identidade de gênero, cristalizado nos anos cinquenta e sessenta”. No afã de elaborar superações teóricas sucessivas, Haraway aponta que algumas

(...) críticas não historicizaram ou relativizaram culturalmente as categorias 'passivas' de sexo ou natureza. Assim, as formulações de uma identidade essencial como homem ou como mulher permaneceram analiticamente intocadas e politicamente perigosas. (HARAWAY, 2004, p. 218) 
Corroborando as vozes críticas mais tradicionais sobre o romance, seguem aspectos de HT que marcam a identificação do romance com a agenda feminista da segunda onda, resumidos em alguns tópicos:

(a) o reconhecimento da autonomia do corpo: no romance, há uma ênfase na questão da fisiologia e destaque para a submissão a regras que interferem na autonomia sobre o próprio corpo o relato de Aia Offred aponta a todo tempo para um controle de seu corpo de mulher, propriedade administrada pelo Estado e usufruída pelo Comandante Fred, que é resultado da diferença abismal entre homens e mulheres, conferida pela marcação biológica;

(b) o questionamento do estado laico: em Gilead, o discurso religioso é entremeado ao discurso estatal, legitimando moralmente a submissão feminina no romance - um exemplo seria a discussão a respeito da decisão sobre a maternidade e das obrigações morais decorrentes da fertilidade (o coito sexual é previsto segundo ditames religiosos e as crianças geradas neste ato seriam destinadas conforme os "melhores interesses" daquela sociedade);

(c) a tematização das sex wars: quando o tema da pornografia é suscitado, no romance, faz alusão a este embate entre militantes feministas que se colocavam contra a indústria pornográfica. Como exemplo, Andrea Dworkin junto com Catharine MacKinnon almejavam leis que restringissem a pornografia, que era compreendida como forma de exploração inaceitável e chegaram a postular a Antipornography Civil Rights Ordinance por volta de 1983. Por outro lado, Ellen Willis (que criou o termo pro-sex feminism"), Rubin Gayle e outras teóricas entendiam que este movimento anti-pornografia ocultava um julgamento moral e uma ameaça a práticas sexuais fora do padrão heteronormativo - neste âmbito, foi criada a Feminists Anti-Censorship Taskforce (FACT) em 1984. Esses embates dividiram consideravelmente a militância;

(d) embates sobre "tipos de militância feminista": no romance, é patente a existência de duas personagens que seriam estereótipos de feministas - a mãe de Offred, militante que parece aludir às feministas da antiga esquerda comunista, e a amiga lésbica de Offred, Moira, que estaria mais alinhada a um feminismo LGBT dos anos 1980;

(e) o trabalho doméstico: grande parte do romance trata das minúcias do trabalho doméstico executado na casa do Comandante Fred e ilustra os debates internos de Offred, 
questionando, por intermédio da reflexão a respeito do trabalho das outras, a invisibilidade dessas ocupações.

Tendo esses tópicos da agenda feminista examinados, não é de se admirar que grande parte da crítica deste período inicial da produção de Margaret Atwood se debruce sobre a questão dos direitos das mulheres, definições de gênero e questões conexas.

Especificamente, a análise sobre como o trabalho doméstico é tratado no livro traz alguns acréscimos para a interpretação, pois é possível verificar como a forma do romance possui imbricações com questões ideológicas do best-seller.

Primeiramente, para contextualizar, os debates a respeito do valor do trabalho doméstico ganharam visibilidade no feminismo em dois momentos históricos anteriores, na Europa e América do Norte:

(...) durante a Depressão, quando as súbitas transformações sociais e econômicas provocaram mudanças nas relações das pessoas com o emprego e na maneira como eram concebidos o trabalho, a produtividade e os papéis na sociedade" e depois, nos anos de 1950, com o retorno das mulheres ao âmbito doméstico que, por conta da guerra, tinham ido trabalhar nas fábricas, "período de reajustamento à vida do lar, o que se tornou possível e até agradável graças à disponibilidade de novos equipamentos eletrodomésticos e de novos recursos dos meios de comunicação na esfera doméstica. (WILLIS, 1997, p. 112) (44 $^{34}$

Tendo em vista que o romance foi produzido nos Estados Unidos da década de 1980 (quando já se observa o ingresso maciço das mulheres brancas de classe média no mercado de trabalho), uma maneira de representar o retrocesso pelo qual essa nação teria passado para se transformar em Gilead é mostrar quanto tempo o trabalho doméstico ocupava na vida das mulheres, sendo praticamente a única atividade feminina possível neste futuro distópico, abarcando desde as pobres trabalhadoras até as senhoras das casas.

Assim, a primeira parte do romance traz, majoritariamente, o espaço privado, o que é doméstico, como o espaço da ação do romance. Essa característica aproxima a forma de HT à larga tradição de romances de língua inglesa voltados para mulheres - de Pamela, passando pela produção de Jane Austen, por Mrs. Dalloway, até chegarmos a outros romances da própria Atwood, como Lady Oracle. Segue um exemplo que ilustra o ponto:

\footnotetext{
${ }^{34}$ As considerações são válidas para os estudos feministas situados nos Estados Unidos e Europa.
} 
Rita está lá, sentada à mesa, descascando e fatiando cenouras. Cenouras velhas, são essas, grossas, guardadas por tempo demais no inverno, barbadas devido ao período de armazenamento. As cenouras novas, macias e claras só estarão maduras daqui a semanas. A faca que ela usa é afiada e reluzente e tentadora. Gostaria de ter uma faca como aquela. (ATWOOD, 2006, p. 62)

Entretanto, é fundamental atentar para a posição da narradora. Por mais que tenha cuidado ao descrever o trabalho doméstico executado ao seu redor, Aia Offred não está destinada a tais tarefas duras, com raras exceções, como fazer compras. Há uma configuração de classe social na narrativa: embora Offred esteja confinada e tenha o corpo escravizado, a aia é servida e cuidada, tendo muitos pequenos privilégios. Seu lugar por excelência é seu quarto, onde permanece aprisionada boa parte dos dias, aguardando cerimônias e ordens, mas é alimentada e tem as roupas limpas por outras mulheres.

Então, outro tema ganha prevalência, também típico da tradição de produtos culturais destinados a mulheres: o tema da espera. Estando livre de executar tarefas duras e tendo que ficar em seu quarto, Offred pouco pode fazer a não ser divagar, solitária:

Há tempo de sobra. Esta é uma das coisas para as quais não estava preparada - a quantidade de tempo não preenchido, o longo parêntese de nada. (ATWOOD, 2006, p. 87)

A espera é o gatilho para elucubrações mentais e aqui o sentimento de nostalgia impera, com recordações saudosas de um passado agora idealizado como "livre". Frise-se que o "passado da narrativa”, Estados Unidos pré-Gilead, coincide com a década de 1980, bem durante a exacerbação do backlash: nas memórias da aia Offred, não há nenhum backlash, somente dias de liberdade. Parece que o golpe de estado sofrido pelos Estados Unidos, transformado agora em Gilead, apaga todos os traços negativos desse tempo pretérito, cimentando um passado glorioso e livre. O sentimento nostálgico opera de modo a apagar os Estados Unidos reais em que Offred vivia, de modo que refaz os anos do backlash em uma aura de liberdade idealizada, que dificilmente teria se materializado. Esse sentimento é reavivado quando a Aia lê revistas antigas:

Luke e eu costumávamos passear juntos, de vez em quando, por estas ruas. Costumávamos falar em comprar uma casa como uma dessas, uma grande e velha casa, e restaurá-la. Teríamos um jardim, balanços para crianças. Teríamos filhos. Embora soubéssemos que não era muito provável que algum dia viéssemos a ter condições para isso, era um assunto de conversa, uma brincadeira de domingos. Tamanha liberdade, agora, parece quase sem importância. (ATWOOD, 2006, p. 35) 
É possível afirmar que a agenda feminista com a qual o romance está filiado possui traços liberais. Narra-se do ponto de vista da mulher de classe média imobilizada, pois clamores por mudanças sociais poderiam modificar suas conquistas anteriores e terminar com seus parcos privilégios (ficar no quarto à espera e fazer pequenas compras em lugar de trabalhar). Após anos de pleno emprego e melhorias no acesso ao consumo, "revolução era a última coisa em que as massas proletárias pensavam" (Hobsbawm, 2012, p. 296). Na era do Desmoronamento, a decaída do bloco de países soviéticos fez com que o slogan de Margaret Thatcher, "There is no alternative", tão repetido a ponto de ser abreviado como TINA, respondesse calando qualquer impulso utópico.

\subsection{HT, imaginar o feminismo somente dentro do possível}

$\mathrm{Na}$ curta segunda parte do livro, um dos temas centrais do texto seria a desconfiança e o questionamento a respeito da produção de saberes e seus lugares, muito em voga em nossos tempos e que produz ecos em discussões do feminismo contemporâneo. A academia, instituição que mesmo em um futuro muito distante terá o seu prestígio assegurado, é retratada como corrupta, misógina e tratando com frivolidade temas de violações graves a direitos humanos, que seria o caso do relatório em $O$ conto da Aia. Como citado anteriormente, a plateia, longe de se sentir indignada com a exposição de horrores e piadinhas misóginas, aplaude e incita o discurso do professor.

Em superfície, um dos temas dessa segunda parte seria, sem dúvida, o questionamento da produção de saber e sua utilização política como forma de manutenção de privilégios de classe e perpetuação das diferenças entre gêneros. Entretanto, se formos mais fundo na análise, poderia ser sugerido que a desconfiança no que diz respeito à academia não atinge, contudo, apenas a produção da ciência em geral: há um subtexto importante que coloca em perspectiva a própria produção teórica a respeito do feminismo à época.

Retomando-se o contexto histórico em que o livro foi produzido e alguns dos debates da segunda onda do feminismo, há narrativas que apontam para a "capitulação" do feminismo ante os "muros da academia" no período.

Clare Hemmings menciona as críticas à academização dos "estudos de gênero", que agora seriam o título acadêmico para "feminismo" - as acusações tratam-nos por "apolíticos", "autorreferentes" e "frequentemente interpretados, em contextos pedagógicos e conferências, como 
agressivamente inacessível”, acusações geralmente atribuídas às autoras Judith Butler, Donna Haraway e Gayatri Spivak. Tais "contranarrativas" chegam a denominar o estado de coisas por "morte do feminismo".

Clare Hemmings analisa estas contranarrativas que se opõem ao pós-estruturalismo pelas características da nostalgia (marcam a despolitização ou o sentimento de retorno para a época em que o feminismo convergia a um propósito comum) ou do retorno (revalorização de um passado imaginado) - a autora chama a atenção para a categoria de progresso/retrocesso que marca ambos os discursos. ${ }^{35}$

Para reforçar este subtexto, cita-se Mariza Corrêa quando comenta, no contexto brasileiro, a igual clivagem entre "militantes" e "acadêmicas", ilustrando a tensão que envolve o processo de academização dos estudos de gênero:

Esses grupos recém-criados eram, é claro, tão atravessados por dissensões políticas quanto quaisquer outros: ainda que a imprensa homogeneizasse o movimento, falando sobre as feministas, éramos de fato grupos com lealdades muito diversificadas - em relação à Igreja, ao Partido Comunista, ou à Universidade. Assim, uma das questões que reiteradamente aparecia nas nossas discussões era a clivagem entre militantes e pesquisadoras, clivagem que se tornou importante à medida que a pesquisa sobre a situação da mulher no país ganhou preeminência sobre os movimentos de mulheres. (CORREA, 2001)

O texto de Atwood pode ser lido a partir desse subtexto com ganhos interessantes de interpretação: se, por um lado, a estrutura circular, desde o início, coloca sob suspeita quem narra (os narradores de toda a história são, em sua essência, dois homens), ou seja, deve se colocar o que é narrado sob suspeição, no subtexto se coloca sob suspeita a própria produção acadêmica sobre o feminismo.

Nesse aspecto, o caráter apontado de fim das utopias feministas é fundamental para a compreensão da dimensão toda do livro. Fredric Jameson aponta uma crítica mais profunda a esse respeito, dado que o livro é também considerado a primeira distopia feminista:

(...) o Handmaid's tale (1985) de Margaret Atwood, (...) foi considerado como a primeira distopia feminista, dando assim notícia do fim da rica tradição de trabalhos feministas no gênero da utopia. (JAMESON, 2006a, p. 177)

\footnotetext{
${ }^{35}$ Ante as clivagens narrativas expostas, Hemmings faz um balanço, considerando a importância de se tecer relações entre as contestações e, acima de tudo, evitar um processo linear de deslocamento, de modo a deixar vias de debates sempre abertas. (HEMMINGS, 2009)
} 
Reforçando esta linha de raciocínio, não é à toa que HT traz dois estereótipos de militantes feministas: a mãe de Offred, identificada com os movimentos da esquerda tradicional comunista, cujo destino é uma espécie de deportação, e Moira, a melhor amiga de Offred, lésbica e rebelde que acaba por ser condenada à prostituição.

Na figura da mãe, são retratadas no estereótipo a "intolerância" e a "solidão" que este tipo de militância anticapitalista e consistente na radicalidade traria - tanto que a mãe termina por ser enviada às colônias. Em um dos episódios, antes do golpe de estado, depois de tomar umas doses, a senhora xinga o genro de "porco chauvinista" e desdenha de seu simples hobby de cozinhar, argumentando que ele foi obtido depois de muita luta de suas companheiras. Na figura da amiga Moira, caracterizada como uma representante do "feminismo da diferença", está clara sua preferência sexual e as vantagens da prostituição em Gilead, que soam para narradora como capitulação:

De qualquer maneira, veja sob o seguinte ponto de vista: não é tão ruim, há mulheres em penca por aqui. Paraíso de sapatão, você poderia chamar. (ATWOOD, 2006, p. 299)

Entre Moira e a mãe de Offred, resta uma ligação: "Sua mãe é uma pessoa impecável", diz Moira para Offred, “sua mãe é uma gracinha” (ATWOOD, 2006, p. 303).

Diferente da mãe e da amiga, ante a situação de confinamento e controles totais, a narradora parece manter certa "sanidade pacífica" e equilíbrio mental, ${ }^{36}$ como se os valores de Gilead a absorvessem, a rendessem (“A república de Gilead, dizia tia Lydia, não conhece fronteiras. Gilead está dentro de você”). Nas reflexões de Offred, encontra-se um tom depressivo sobre a própria situação, um tom que chega à indiferença, mas nunca à rebelião:

Estou em desgraça, o que é oposto de graça. Deveria me sentir pior quanto a isso.

Mas sinto-me serena, em paz, impregnada de indiferença. Não permita que os bastardos reduzam você a cinzas. Repito isso para mim mesma, mas não me transmite nada. Seria a mesma coisa que você dizer: Que não haja ar; ou: Não seja. (ATWOOD, 2006, 343)

O texto apresenta-nos um panorama de raras (ou nenhuma) saídas, diante desta distopia total do feminismo. Pouco a pouco, as frestas por onde se poderia vislumbrar alteridades possíveis

36 "Nenhuma esperança. Sei onde estou, e quem sou, e que dia é hoje. Esses são os testes, e estou sã. A sanidade é um bem valioso; eu a amealho e guardo escondida como as pessoas antigamente amealhavam e escondiam dinheiro. Economizo sanidade, de maneira a vir a ter o suficiente, quando chegar a hora”. (ATWOOD, 2006, p. 135) 
são tapadas - a história e sua reconstituição por acadêmicos não são confiáveis, as militantes e suas causas são como palavras ao vento, fáceis de serem combatidas e de serem afastadas, os próprios homens (nas figuras de Nick, Luke e mesmo o Comandante) parecem se importar pouco com a situação. O que sobra é a narrativa da resignação e da parca sobrevivência.

Assim, o romance parece perfazer duas das antigas vocações do gênero romanesco destinado ao público feminino: gratificar a resignação, concedendo uma dimensão digna à falta de outras soluções que não sejam prosseguir na adaptação a padrões socialmente estipulados, e ensinar como se portar e refletir. No momento atual, parece ser um alívio mental após a avalanche de questões que o feminismo colocara anteriormente e que parecem, ainda hoje, sem muitas respostas ou solução. Lembrando os velhos ensinamentos de Richardson sobre os próprios escritos (também best-sellers):

(...) instruction without entertainment (where I am capable of giving the best) would have but few readers. Instruction, Madam, is the pill; amusement is the gilding. ${ }^{37}$

Se, à época da publicação de Pamela (ano de 1740, romance epistolar de Richardson que narra "a história da heroína que resiste a todas as tentativas de sedução por parte de seu senhor, acabando por conquistar casamento e ascensão social como recompensa" (VASCONCELOS, [20])), as leitoras de Richardson "conseguiam transformar a impessoalidade e o tédio do mundo real num modelo gratificante em que cada elemento se convertia em algo que proporcionava emoção, admiração e amor" (WATT, 2007, p. 177), agora as leitoras de HT transformam a resignação e o sentimento de impotência ante o backlash em um modelo gratificante, no qual o sentimento de capitulação das conquistas femininas se converte em compreensão.

Atwood, celebrada como "defensora do direito das mulheres", neste best-seller faz com que as leitoras, que projetam a própria desilusão e a resignação ante o recrudescimento contra as conquistas feministas do capitalismo tardio, sintam-se compreendidas e acolhidas, ao menos por alguns instantes, o que poderia explicar o sucesso estrondoso do romance, inclusive entre feministas.

${ }^{37}$ RICHARDSON, Samuel, em carta para Lady Elchin em 22 de setembro de 1755 (reunida em "Correspondence", 1804). 
Corrobora esta leitura de gratificar a resignação e de sugerir o como se portar como mulher no capitalismo tardio a análise sobre o andamento cronológico arrastado da primeira parte do livro.

O tom dramático e memorialista confere várias idas e vindas, explicações detalhadas sobre pormenores domésticos, nunca solucionando o enredo em alguma vitória ou ato inesperado de Offred - quando ocorrem, são dissolvidos em outras memórias. Embora os fragmentos narrativos sejam entrecortados entre vários passados e um longo e tedioso presente, a falta de "golpe dramático" no enredo e a lenta sucessão de pequenos problemas domésticos favorecem que aproveitemos uma reflexão muito interessante sobre a estetização da "espera" e sua recepção no público feminino:

"A narrativa, colocando obstáculos cada vez mais complexos entre o desejo e sua realização, faz da espera um fim em si” - esta consideração de Tania Modleski, que se refere ao gênero das telenovelas, poderia perfeitamente se referir à primeira parte de HT. Susan Willis, quando discute como Modleski trata a dimensão da espera e o gênero televisivo, traz considerações que podem ser extrapoladas ao âmbito de HT:

Modleski compara habilmente a espera-componente-formal-da-telenovela com a experiência vivida pela dona de casa. Sozinha em casa, seu marido no trabalho, um ou todos os seus filhos na escola, a dona de casa desempenha as tarefas cotidianas necessárias à manutenção do lar e da família num ambiente em que tudo é espera. (...) Modleski conclui que o apelo das telenovelas reside na maneira com que elas transformam a espera em um prazer - a telenovela estetiza a espera e permite que a dona de casa transcenda sua experiência real e frustrante da espera e a conceba como um prazer. (WILLIS, 1997, p. 16)

Em HT, a estetização da espera não faz apenas com que a leitora transcenda a experiência real e frustrante da espera em si (que seria o caso levantado das telenovelas nos anos 80). Aqui, a espera possui um componente um pouco diferente, pois estetiza a espera no âmbito do confinamento - tanto no sentido do espaço doméstico e corporal quanto no sentido do confinamento intelectual. Offred, mais do que prisioneira, não possui o direito ao debate, à reflexão nem ao próprio corpo. A experiência real das mulheres, que se veem pressionadas cada vez mais a possuírem corpos com padrões de beleza impossíveis, a serem cabeças de família, a funcionarem como muros de arrimo em tempos de crise, acuadas nas liberdades sexuais e, ao mesmo tempo, seguirem esperando "seja pelo tocar do telefone, pelo soninho do nenê ou pela reunião da família" 
(WILLIS, 1997, p. 16), é estetizada em HT de maneira a permitir que a angústia e a pressão sejam concebidas como entretenimento, oferecendo um espaço catártico de compreensão.

Em resumo, Margaret Atwood cria uma aporia. Por um lado, por meio de uma estética que propicia o conforto momentâneo e a sensação de compreensão pela via do entretenimento, o romance ensina formas de se pensar e agir como mulher nesses novos velhos tempos. Por outro lado, as lutas existentes para a emancipação da mulher, que propõem um "outro programa" além do capitalismo, acabam sendo vítimas de suspeição ou de fracasso (a academia sob suspeita, a militância desacreditada), não sendo possível desenhar a alteridade possível, restando a recomendação "imagine somente dentro do possível”. 


\section{Capítulo 5 - Forma, funções ideológicas e impulsos subjacentes}

\section{$5.1 O$ romance como gênero ambivalente e acomodação de novos materiais}

A impossibilidade de perfazer utopias confere às duas obras uma maneira peculiar de arranjos formais. Ao mesmo tempo, é por intermédio da configuração das formas que se representa a impossibilidade utópica, como se estivéssemos diante das propriedades de um dispositivo literário. Nos dois romances, emergem estratégias formais bastante resistentes e auxiliam a não delinear respostas unívocas sobre o que poderia ser "um mundo melhor" - parece que as propriedades deste dispositivo literário agem mais para trazer esquivas do que para resolver as aporias que aportam.

O raciocínio inicia-se com uma pequena digressão sobre as características centrais da forma "romance" e sua existência na sociedade pós-industrial.

Muito da crítica de inclinação marxista na primeira metade do século XX irá caracterizar o romance como "forma problemática" ou "epopeia burguesa", investigando a fundo a questão da forma e da correspondência entre as categorias que estruturam a criação literária e a consciência coletiva. ${ }^{38}$ As análises são fortemente influenciadas por duas obras: Teoria do romance, do jovem Lukács (1914), e a Posição do narrador no romance contemporâneo, de Adorno (1954, p. 165) ${ }^{39}$, o qual irá formular o conceito "o romance como epopeia negativa", condição na qual o indivíduo liquidaria a si mesmo (ADORNO, 2003, p. 55). Adorno aponta a situação paradoxal do gênero romance, em contraste com o gênero épico: em nossa sociedade pós-industrial, não seria mais possível fazer uma narração e, no entanto, a forma do romance assim o exige - conforme elucida Leandro Konder:

\footnotetext{
38 Sobre a inovação do jovem Lukács na Teoria do romance: “O jovem Lukács subverteu essa perspectiva ao buscar uma nova correlação entre literatura e sociedade. Tal correlação não se dá mais no plano do conteúdo, mas da forma, da correspondência entre as categorias que estruturam a criação literária e a consciência coletiva". (FREDERICO, 2005).

${ }^{39}$ Segundo Rolf Tiedemann, Adorno apresentou o texto em uma conferência na cidade de Berlim, o qual foi publicado na Revista Akzente em 1954 e depois iria integrar o primeiro tomo de Notas de literatura publicado em 1958.
} 
As bases da atitude assumida pelo narrador se acham, segundo Adorno, destruídas pelas condições com que nos defrontamos hoje. Com a administração generalizada levada a cabo pelo neocapitalismo, com a manipulação das condutas humanas, a pretensão de refletir a realidade acaba resultando num acumpliciamento com o poder, na medida em que não se pode passar de reprodução da mera "fachada" do real. Impõe-se ao escritor, portanto, a renúncia ao ponto de vista "privilegiado" do narrador (KONDER, 1997, p. 16).

Há uma posição bem interessante, com ganhos de interpretação a respeito desse ponto, que deveria compor uma tríade com as obras citadas de Lukács e Adorno: o ensaio O romance está morrendo - contribuição à teoria do romance, de Ferenc Fehér (1974), que dialoga com o Lukács maduro e também com as reflexões de Lucien Goldmann na década de 1960. Em lugar de apostar na "morte do romance" ou seu "caráter problemático", Fehér sublinha um outro caráter do gênero: sua ambivalência. Citando um trecho de Carlos Frederico que contextualiza o debate:

(...) ao estudar as perspectivas do gênero romance, [Ferenc Fehér] criticou duramente as posições de Goldmann, a partir das reflexões do Lukács marxista de Escritos de Moscou. Para Fehér, a glorificação da epopeia e o consequente rebaixamento do romance é um equívoco. O romance não é um gênero problemático, mas ambivalente. Ele é fruto da sociedade burguesa e, como tal, sofre essa limitação; mas essa sociedade, ao contrário do mundo antigo, é estruturada sobre formas puramente sociais, e não mais naturais (FREDERICO, 2005).

$\mathrm{Na}$ introdução de Leandro Konder para a versão brasileira de $O$ romance está morrendo?, explica-se o conceito do que seria então gênero ambivalente:

Com o trabalho de Fehér, estamos em condições de compreender, efetivamente, porque o romance não está para morrer. O romance - observa Fehér - não é um gênero problemático e sim um gênero ambivalente. Num determinado nível, ele expressa a sociedade burguesa, com a qual nasceu e se desenvolveu. Em outro nível mais profundo, entretanto, o romance como gênero expressa a sociedade 'puramente social', a superação das barreiras naturais e dos 'laços de sangue', a radical socialização da vida e a generalização do caráter alternativo com que a atividade teleológica se apresenta aos olhos do sujeito consciente que a realiza". (Grifos no original.) (KONDER, 1997, p. 24)

Sendo ambivalente, o romance, pelas suas próprias características formais, consegue acomodar materiais novos provenientes da sociedade burguesa. Desde o século XIX, é a principal expressão da literatura de língua inglesa, passível de transmitir um novo tipo de consciência em formas comuns, fato este sem precedentes (WILLIAMS, 1970). Com "materiais novos" quer-se 
dizer maneiras diferentes de sociabilização e alterações nas estruturas de sentimento - as demandas do feminismo e suas utopias seriam exemplos de materiais novos nos romances em questão.

Exemplificando, com citações dos romances que evidenciam essas novas demandas, em LHD, propõe-se que se imagine uma civilização que estaria livre do complexo de Édipo e da ameaça de crimes sexuais, como o estupro - discussão que dificilmente tomaria forma no alto modernismo, principalmente, porque não era uma discussão premente dentro do horizonte histórico da época. O tema é acomodado por intermédio do uso de uma paródia de anotações científicas no capítulo A questão do sexo, nas observações de campo de Ong Tot Oppong, investigadora do primeiro grupo de terra ekumênico em Gethen/Inverno:

Considere: uma criança não tem nenhum relacionamento psicossexual com sua mãe ou seu pai. O mito de Édipo é inexistente em Inverno.

Considere: não existe sexo sem consentimento, não existe estupro.

Como ocorre com todos os mamíferos, exceto o homem, o coito só pode ser realizado por convite e consentimento mútuo; do contrário, não é possível. A sedução certamente acontece, mas deve ser tremendamente oportuna.

[Trecho do capítulo A questão do sexo, das observações de campo de Ong Tot Oppong, investigadora do primeiro grupo de terra ekumênico em Gethen/Inverno, ciclo 93 A.Y. 1448. (LE GUIN, 2005, p. 95)]

Em HT, discute-se a repressão às mulheres em Gilead e a repressão às feministas nos Estados Unidos nos anos de 1980. A acomodação formal do tema na obra ocorre por um mecanismo bem conhecido pelo jornalismo na televisão - a justaposição de imagens, igualando conteúdos pela forma sequencial de exibição, embora os conteúdos tenham mensagens bastante distintas (como exemplo, após noticiar muitos feridos em uma manifestação, se noticia o ganhador da loteria e a previsão meteorológica para o final de semana). No romance, a justaposição é a forma eleita para apontar como a educação das aias na nova sociedade teocrática é feita: mostra-se a pornografia como motivo de assassinato de mulheres e mostra-se as manifestações políticas feministas como atitudes de mulheres desocupadas e ignóbeis. Na narração de Offred, primeiro há menção de filmes com mulheres sendo humilhadas e mortas para se justificar a tutela religiosa do Estado de Gilead e, na sequência da narrativa, a aia conta que assiste a um documentário sobre as "Não mulheres", quando pode ver sua mãe participando em uma manifestação pró-aborto. A própria narrativa adotada essa forma sequencial, marcada pela justaposição de imagens, para igualar as mensagens e criar uma relação entre os temas: 
Por vezes a fita que ela [tia Lydia] exibia era um velho filme pornográfico, dos anos 70 ou 80. Mulheres ajoelhadas chupando o pênis ou armas, mulheres amarradas ou com coleira de cachorro ao redor do pescoço, mulheres penduradas em árvores ou de cabeça para baixo, nuas, com as pernas mantidas abertas, mulheres sendo estupradas, surradas, mortas. (...) Reflitam cuidadosamente sobre as alternativas, dizia tia Lydia. Vocês vêem como as coisas costumavam ser? Isso era o que eles pensavam das mulheres na época. A voz dela tremia de indignação (...).

Por vezes, contudo, o filme seria o que tia Lydia chamada de um documentário de Não mulheres. Imaginem, dizia tia Lydia, desperdiçarem seu tempo assim, quando deveriam ter estado fazendo alguma coisa útil (...).

Atrás dessa mensagem há outras faixas, e a câmera as mostra brevemente: LIBERDADE PARA ESCOLHER. QUE TODO BEBÊ SEJA UM BEBÊ QUERIDO. RETOMEMOS NOSSOS CORPOS. VOCÊS ACREDITAM QUE O LUGAR DE UMA MULHER SEJA NA MESA DA COZINHA? Debaixo da última faixa há um desenho de um corpo de mulher, deitada numa mesa, o sangue pingando dela.

Essas acomodações de novos materiais nos romances, que despontam segundo ocorrências históricas, não ocorrem harmonicamente, transformando a própria forma-romance, ao mesmo tempo em que a forma-romance se impõe sobre essas demandas dos tempos, daí a importância da noção de ambivalência.

O romance, como gênero ambivalente, traz ainda outra característica que possibilita essas acomodações - seu acréscimo de emancipação (FEHER, 1997, p. 38). Em uma época em que a produção estética é integrada à produção de mercadorias em geral, em que a cultura é a cultura da imagem, do simulacro e do enfraquecimento da historicidade (JAMESON, 2006a, p. 30), o espírito do make it new do alto modernismo continua vigente, ditando a necessidade de usar "formas experimentais e inovadoras", o que ainda se revela importante para duas obras que se apresentam como mercadoria editorial, que devem conter certo frescor e autenticidade em suas elaborações. Neste caso, discutir a inexistência de estupro em uma sociedade na forma de paródia de relatório científico ou discutir campanhas pró-aborto utilizando a forma televisiva de justapor imagens com conteúdos distintos são exemplos deste acréscimo de emancipação, que consegue prover esta inovação em temas e formas, aspecto fundamental a dois produtos que pertencem à cultura de massa. 


\subsection{Um método capaz de fazer justiça}

Fredric Jameson possui um texto muito importante, que fornece um método de análise para apontar e interpretar as funções ideológicas e utópicas da cultura de massa, bastante útil a estas inquietações: Reificação e utopia na cultura de massa (JAMESON, 1994).

Partindo do legado da Escola de Frankfurt sobre a estrutura mercantil da cultura de massa, linha crítica que elencou um "inventário exaustivo de modelos variantes e de outros traços além da reificação mercantil", Jameson localiza um ponto frágil nos escritos frankfurtianos, ponto que fica mais evidente após a experiência histórica pós-moderna: os frankfurtianos trariam uma valorização da alta arte modernista tradicional, tida como positiva e como o locus de uma produção estética 'autônoma', genuinamente crítica e subversiva". Segundo Jameson, artistas como Schoenberg, Beckett e Brecht não poderiam servir mais como o padrão eternamente citado para “aferir o 'estado degradado' da cultura de massa” (JAMESON, 1994, p. 6), passando o crítico a sugerir uma maneira de lidar com ela - considerá-la uma manifestação dialeticamente interdependente da alta cultura, sendo a tarefa da crítica refletir a respeito do capitalismo tardio e de sua dependência, agora estrutural, da cultura de massa.

Jameson sugere ainda afastar a falsa questão do "valor da obra", o que remonta a binariedades e essencialismos entre categorias que pouco ajudam na análise desses produtos culturais (como bom e mau, positivo e negativo etc.), entendendo a produção artística da cultura de massa como específica do processo histórico, sendo tarefa do crítico tratar de materiais provenientes de subgêneros literários bastante fixos - como gótico, best-seller, suspense, ficção científica, biografia, pornografia -, livros que concorrem com produtos culturais vindos do cinema e da televisão e que devem cumprir, no pacto com o leitor, suas expectativas de consumo mercantilizadas, bastante diferentes das expectativas modernistas:

(...) os antigos gêneros pré-capitalistas eram signos de algo como um 'contrato' estético entre o produtor cultural e um certo público homogêneo de classe ou grupo; eles extraíam sua vitalidade do status social e coletivo (que, por certo, variava amplamente de acordo com o modo de produção em questão), da situação da produção e consumo estéticos - vale dizer, do fato de que a relação entre artista e público era ainda, de um modo ou de outro, uma instituição social e uma relação social e interpessoal concreta, com sua própria validação e especificidade. Com o advento do mercado, esse status institucional do consumo e da produção artísticos desaparece: a arte passa a ser um ramo a mais da produção de mercadorias, o artista perde todo o status social e defronta-se com as opções de se tomar um poete maudit 
ou um jornalista, a relação com o público é problematizada, este se transforma num virtual public introuvable. (JAMESON, 1994)

No caso, os romances de Le Guin e de Margaret Atwood são usufruídos pelos leitores nessa relação de mercadoria, pertencendo aos subgêneros, respectivamente, ficção científica e bestseller (mesmo que possa haver esforços críticos para inseri-las na continuidade da "alta literatura" ${ }^{40}$ e essas observações de Jameson são interessantes para não se elaborar uma análise romantizada dentro de padrões estéticos positivistas e calcados em teorias sobre o "valor da obra literária”, que não auxiliam a desvendar camadas menos óbvias dos textos. Categorias de análise como "originalidade" e "estilo", em subgêneros em que se espera que cumpram expectativas de quem os usufrui, já não são mais interessantes, pois se aguarda que esses produtos repitam esquemas preconcebidos em uma desejável repetição, permitindo ao público a agradável sensação de "ver a mesma coisa vezes e vezes a fio". Para pontuar ainda observações sobre a forma romance no pós-modernismo, é interessante lembrar-se de não tomar por empréstimo critérios de análise do alto modernismo como referência - por exemplo, as pretensões formais de James Joyce ou Virginia Woolf estariam longe de Ursula Le Guin ou Margaret Atwood - aquelas que poderiam ser resumidas pela frase de Lodge: “O romance moderno não tem um verdadeiro começo, visto que nos faz mergulhar num fluxo constante de experiência, com o qual nos familiarizamos progressivamente por um processo de inferência e associação; o final geralmente é aberto ou ambíguo"(LODGE, 1999, p. 394). Aqui não se trata mais de louvar o "inconfundível estilo de cada autor" e, sim, de vislumbrar como cada vez mais tênue a fronteira entre as denominadas alta cultura e cultura de massa e o aparecimento de novos tipos de texto, "impregnados das formas, categorias e conteúdos da mesma indústria cultural que tinha sido denunciada com tanta veemência por todos os ideólogos do moderno" (JAMESON, 2006a, p. 28).

$\mathrm{Na}$ análise deste corpus, encerra-se, assim, um confronto metodológico que Jameson pretende resolver, sugerindo outra maneira de análise, uma metodologia que aqui será considerada para se trabalhar a emergência da questão utópica nos dois romances:

Precisamos, assim, de um método capaz de fazer justiça simultaneamente às funções ideológicas e às utópicas ou transcendentes da cultura de massa. É o

${ }^{40}$ A observação é válida principalmente para a fortuna crítica relacionada à obra de Atwood, que constrói a argumentação a respeito da valorização da obra dentro de marco estético modernista. No caso de Le Guin, em se tratando de obra de ficção científica, gênero cuja crítica já percebe que a produção estaria à margem da literatura tida como "alta cultura", essa tentativa é menos frequente. Aqui talvez se possa ver o alcance do pensamento do crítico Darko Suvin, autor que logrou estabelecer critérios próprios para este gênero literário. 
mínimo necessário, como pode testemunhar a supressão de algum desses termos: já comentamos a esterilidade do antigo tipo de análise ideológica, o qual, ignorando os componentes utópicos da cultura de massa, culmina na denúncia vazia da função manipulatória e do estado degradado daquela. Mas parece igualmente óbvio que o extremo complementar - um método que celebraria os impulsos utópicos, na ausência de qualquer conceito ou menção da vocação utópica da cultura de massa simplesmente reproduz as ladainhas da crítica de mitos, na sua forma mais acadêmica e esteticizante, e priva esses textos de seu conteúdo semântico, ao mesmo tempo em que lhes subtrai sua situação social e histórica concreta. (JAMESON, 2006a, p. 18)

O texto de Jameson, então, possui um segundo movimento, em que trata de propor chaves interpretativas para filtrar os "impulsos subjacentes", apresentando, então, sua metodologia. Procura defender que a função de ideológica de produtos da cultura de massa não se completa sem a presença do potencial utópico e transcendente, estando esta dimensão implícita mesmo no mais degradado tipo de cultura de massa, não importando "quão debilmente, negativa e crítica da ordem social, da qual, enquanto produto e mercadoria, deriva”. A hipótese é que as obras de cultura massificada não conseguem ser ideológicas sem trazerem, dialeticamente, utopias imbricadas, devendo oferecer um "grão genuíno de conteúdo". Apesar de as obras provenientes de cultura de massa também não serem capazes de administrar angústias sobre a ordem social, Jameson faz a seguinte proposta sobre a postura da crítica ante essa incapacidade:

Nossa proposta sobre o poder de atração das obras de cultura de massa defendia que tais obras são incapazes de administrar angústias sobre a ordem social, a menos que primeiro as hajam revivido e lhes tenham conferido alguma expressão rudimentar; agora, procuraremos sugerir que angústia e esperança são duas faces da mesma consciência coletiva, de tal modo que as obras de cultura de massa, mesmo que sua função se encontre na legitimação da ordem existente - ou de outra ainda pior -, não podem cumprir sua tarefa sem desviar a favor dessa última as mais profundas e fundamentais esperanças e fantasias da coletividade, às quais devemos reconhecer que deram voz, não importa se de forma distorcida. (JAMESON, 2006a, p. 19)

Aqui se faz a tentativa de tratar dessas funções ideológicas e funções utópicas em cada um dos romances, observando quais vozes distorcidas apontam esperanças e anseios a coletividade em uma época histórica em que esse vislumbre parece não ser mais possível.

Os romances em análise apresentam esta contaminação pela indústria cultural. Le Guin trabalha dentro da tradição da ficção científica (embora "tradição" seja talvez uma palavra forte para o gênero, pois seria muito recente), que por excelência se configura dentro de uma paisagem "degradada", habitada por "bolsilivros de aeroporto e suas subcategorias do romanesco e do gótico, 
da biografia popular, das histórias de mistério e assassinatos" (JAMESON, 2006a, p. 28). LHD é livro vendido em banca de jornal, e oscila entre a linguagem científica, que pega de empréstimo da antropologia e da astronomia, até momentos de pieguice sobre um amor entre alienígenas. HT é um best-seller cuja linguagem apresenta também oscilações - desde o uso de tom confessional, lições de autoajuda, piadinhas e cenas de suspense.

As oscilações entre essas linguagens e uso de subgêneros, muitos tidos como subalternos diante do panteão modernista, parecem configurar uma formulação própria aos livros, como se $a$ falta de um gênero preponderante, a ausência de um estilo único e essas oscilações constituíssem exatamente a noção de forma desses romances.

\subsection{Descontinuidades de gêneros e a força da tradição em LHD}

Nos romances em análise, manifestam-se diversos tipos de imaginação e de atitudes em face do mundo - emergem os "novos materiais", desejos utópicos ligados à emancipação das mulheres, tentativas de prefigurar a sociedade em outras lentes que não as androcêntricas. Dessa maneira, a forma do romance apenas dará conta de exprimir essas realidades sociais por ser ambivalente, por conseguir absorver outros gêneros literários, e reapresentá-las dentro de sua própria moldura.

A maneira pela qual as autoras trabalham essas novas realidades sociais em cada livro é distinta. Mas ambas lançam mão de um artifício-base: o uso de descontinuidades de gêneros. ${ }^{41}$ Com esse conceito de "descontinuidade de gênero" se quer referir ao uso de um arcabouço linguístico específico - uso de tons, construção de narrador, linguagem, espaço - completamente diferente a cada trecho do livro, como se fosse outra narrativa. Não é simplesmente o tom do narrador que muda, como no caso da volubilidade de Brás Cubas analisada por Schwarz (2000); aqui, é como se as obras fossem formadas por grandes colchas de retalhos de narrativas completamente diferentes entre si, as oscilações a que nos referíamos anteriormente.

\footnotetext{
${ }^{41}$ Considera-se aqui a ideia de gênero literário consolidada pela crítica - nas palavras de Rosenfeld: “(...) o uso da classificação de obras literárias por gêneros parece ser indispensável, simplesmente pela necessidade de toda ciência de introduzir certa ordem na multiplicidade dos fenômenos. Há, no entanto, razões mais profundas para a adoção do sistema de gêneros. A maneira pela qual é comunicado o mundo imaginário pressupõe certa atitude em face deste mundo ou, contrariamente, a atitude exprime-se em certa maneira de comunicar. Nos gêneros manifestam-se, sem dúvida, tipos diversos de imaginação e de atitudes em face do mundo" (ROSENFELD, 2001, p. 19).
} 
Fredric Jameson, em A virada cultural, também partiu das análises de Lukács sobre o romance que inspiraram Fehér, mas com uma crítica que resultará em outro conceito que interessa à ideia de descontinuidade de gênero - o de autonomização como característica do pós-moderno: Jameson vê a reificação modernista em termos de análise, de decomposição e, sobretudo, de diferenciação interna em uma mesma obra. Aqui se refere ao uso de formas distintas colocadas juntas, escolhas que antes seriam consideradas inconcebíveis. Em um paralelo com a noção de taylorização na produção de mercadorias (contemporânea ao modernismo) que irá se tornar a produção em massa - separação de diferentes estágios e sua organização em termos de "eficiência" -, o crítico compara que formas de abstração que pareciam "feias, dissonantes, escandalosas, indecentes ou repulsivas" se tornaram tendência no consumo cultural: "Se a autonomização - o tornar-se independente das partes ou dos fragmentos - caracteriza o moderno, ela também se aplica bastante à pós-modernidade” (JAMESON, 2006b, p. 237-238).

O uso programado de descontinuidade de gêneros possui uma relação muito importante com o tema do presente trabalho: é por intermédio deste artifício que as obras se sustentam, mesmo diante de suas impossibilidades de configuração utópica. Como se o uso de formas descontínuas e autonomizadas apresentasse uma estratégia para tapar buracos imaginativos e desviar a atenção de um todo que não consegue se erguer. Na dialética das formas, por outro lado, o uso reiterado de descontinuidades genéricas poderia contribuir para a configuração das aporias que os romances apresentam. Vejamos como isso se apresenta em cada romance.

A noção de gênero descontínuo presume que o romance tenha por abstração uma forma homogênea inicial - a forma contínua seria considerada a partir das estruturas linguísticas e gramaticais típicas, por exemplo, do romance inglês do século XIX, algo entre o romance "social" (observações e descrições precisas da vida em geral, da comunidade) e o romance "pessoal" (observações e descrições precisas de pessoas, das unidades). Gênero descontínuos ocorreriam todas as vezes em que os textos são compostos por formas heterogêneas, estranhas ao romance.

Traçando-se um paralelo entre a análise que Roberto Schwarz realiza sobre as descontinuidades em Memórias Póstumas de Brás Cubas, ao aludir às interrupções e à volubilidade do narrador de Brás Cubas, o crítico anota os apólogos, anedotas, vinhetas, charadas, caricaturas e outras modalidades curtas, "formas fechadas em si mesmas, e neste sentido matéria romanesca de segunda classe, estranha à exigência de movimento global própria ao grande romance oitoentista" 
(SCHWARZ, 2000, p. 51). Embora a distância com nosso objeto de estudo seja grande, uma lição é possível retirar deste método de análise de Schwarz: como gêneros de cunho subalterno, estranhas à tradição do "grande romance", acabam por perfazer a forma do próprio romance.

$\mathrm{Na}$ ficção científica, é muito comum que autores lancem mão do expediente das descontinuidades genéricas, até com apropriação de gêneros mais próximos à cultura de massa, considerados subalternos diante da tradição do romance no alto modernismo (até a própria ficção científica pode ser caracterizada como subalterna, por ter sua divulgação nesse caldo menos ilustrado) - os livros apresentam divagações sobre antropologia, manuais de pilotar espaçonaves, anotações de experiências genéticas, relatos de aventuras, o que constituiria o "romance em si".

Fredric Jameson analisa este fenômeno em Generic Discontinuities in SF: Brian Aldiss' Starship, ensaio publicado na revista Science Fiction Studies que depois integrará o livro Arqueologias do Futuro (2005). Neste ensaio, Jameson descreve como sucessivamente, em Starship de Brian Aldiss, ocorrem rupturas nos gêneros utilizados entre um segmento de texto e outro, que se poderia chamar de quebrar as "expectativas de gênero" - inicialmente, sugere-se que a obra seja um livro de memórias, depois parece um romance de aventura e assim caminham as páginas do romance até que, em determinado momento, se está diante de uma obra de caráter social ou político. Diferente da estética moderna, em que o tema do romance teria que estar imbricado na linguagem a todo o tempo e por toda a obra, agora é na forma de justapor gêneros distintos que esse caráter temático se estabelece. A técnica por detrás desta forma é a colagem: a colocação, em precária coexistência, de elementos retirados de diferentes fontes e contextos, elementos que derivam, em sua maior parte, de modelos literários mais antigos, forma de justaposição que Jameson irá descrever como "uma espécie de agregação desesperada de tudo o que se têm à mão", que acaba por ter efeito sobre a nossa própria recepção genérica (JAMESON, 2005).

Aplicando-se essas considerações para se pensar sobre as descontinuidades de gênero em LHD: neste romance, há uma profusão de formas literárias distintas, com modos narrativos superpostos, mesclados, e desse modo se constitui, segundo Jameson, quase em uma antologia de diferentes tipos narrativos (JAMESON, 2005, p. 319) - encontram-se de "romance político" até "relato de viagem", textos antropológicos, sobre sexualidades, etc. Entretanto, a amarração das expectativas de gênero atua dentro de um caráter político ou, ainda, refere-se a um tema social: a História do planeta Gethen. 
As narrativas e descrições que se alternam fazem, todas, referência a um mesmo centro o planeta, seus habitantes e a ameaça velada da integração de Gethen ao Ekumen. A colagem aqui também possui função estrutural, pois as "expectativas genéricas" atuam no sentido de formular a pergunta: o que acontecerá com os habitantes do planeta Inverno?

Interessante verificar como a questão das descontinuidades genéricas atua com relação à questão das políticas utópicas e de gênero ( gender).

O crítico Rafail Nudelman discute como os temas ambissexualidade e androginia acabam sendo incorporados na formação do romance, sugerindo que há uma relação entre androginia e unidade que perpassaria grande parte da construção do livro ("um movimento da fragmentação à unidade"). Cite-se trecho do romance LHD abaixo:

Considere: não existe nenhuma divisão da humanidade em metades forte e fraca, protetora/protegida, dominante/submissa, dona/escrava, ativa/passiva. Na verdade, pode-se verificar que toda a tendência ao dualismo que permeia o pensamento humano é muito reduzida, ou alterada, aqui em Inverno. (LE GUIN, 2005, p. 95)

Nudelman (1975) coloca que a concepção do planeta Gethen apresenta o devir do Uno: o que seria geralmente separado na realidade está unido. Até mesmo a maneira pela qual o enredo caminha para uma compreensão e realização desta unidade - resumir a lenda fundadora de LHD na corporificação da androginia - é por intermédio de uma criatura que se relaciona tradicionalmente com a condição não-fragmentada do mundo. Nudelman também acrescenta que não é gratuita a citação sobre a na tradição chinesa com o yin (feminino, esquerda) e o yang (masculino, direita) e o caminho do tao, até mesmo "a divindade chinesa anciã da luz e da escuridão também era andrógina".

O tema da unidade estaria, para Nudelman, presente na própria estrutura do romance, incorporada nas observações sobre a androginia. Inclusive, considera até circular ou una a forma em que a liga espacial hainiana se forma e se constitui: "The space which the League embraces is united and linked only in the sense that it all makes up the League's space; there is no unified system of coordinates or reference points, no grid of relative distances” (NUDELMAN, 1975). A contribuição interessante de Nudelman aqui é apontar como a representação da ausência de divisão entre gêneros (gender) possui uma relação com a própria forma do romance. 
O que escapa à crítica de Nudelman é a oscilação entre os diferentes gêneros literários que compõe o romance e sua relação com os estudos de gênero (gender studies). Embora haja as descontinuidades genéricas já apontadas, existe uma narrativa central que domina as demais - tanto por ser mais extensa como por ter a curva dramática acentuada, dentro de um conjunto de outros textos. Esta é o relatório de Genly Ai, o primeiro Móvel em Gethen/Inverno. Sua dominância é ajudada, além da extensão e dramaticidade, por ter a função estrutural de apresentar aos poucos a cultura dos alienígenas a partir de um padrão humano conhecido. Embora Le Guin procure discutir a ideia de colonização, é a partir da voz do colonizador (ou de um mero batedor a serviço da "metrópole") que temos a narrativa estruturada: o Enviado é um homem.

Os gêneros literários que são utilizados como base para a constituição do relato de Genly Ai são muito próximos do gênero "aventura" - narrativas populares sobre culturas não-ocidentais em que há o predomínio de explicações básicas sobre costumes estranhos e alteridades, entremeados a relatos de viagens. No relatório, encontram-se estes elementos: Ai relata como se vestem, o que comem, viaja a outras regiões, detalha como permaneceu vivo e os perigos que correu. Tradicionalmente, trata-se de um gênero literário voltado a "leitores homens", na construção da ideologia de sua capacidade de dominar a natureza não-conhecida, de apreender e conquistar habitantes de outros lugares, de se relacionar com questões sociais que despontam com o neocolonialismo.

Entretanto, parece que este gênero literário inspirado no romance de aventura não dará conta de explicar a vivência ou as transformações que o próprio narrador irá sofrer em um mundo sem gênero. Genly Ai, na sua fuga pela enormidade do Gelo Gobrin, apaixona-se por Estraven que guarda no corpo a potência adormecida até entrar no cio de ser homem e mulher -, que faz também o papel clássico de "informante nativo". Neste ponto do romance, parece que outro gênero emerge, o parente "feminino" do romance de aventura: o romance sentimental. Estraven, considerado traidor pelo seu povo como uma Malinche, auxilia o Enviado Genly Ai a escapar pelo gelo. Uma vez concluída a missão, entrega seu peito aos tiros de revólver de incursão, colocando fim na trama do amor alienígena que parecia ser impossível.

No ponto alto da revelação:

Vi, então, novamente, e de uma vez por todas, o que sempre tivera medo de ver e vinha fingindo não ver nele: que ele era uma mulher, assim como era um homem. Qualquer necessidade de explicar as origens desse medo desapareceu junto com o 
próprio medo; o que me restou, finalmente, foi a aceitação dele tal como era. Até então eu o rejeitara, recusara-lhe sua própria realidade. Ele estava totalmente correto quando disse que era a única pessoa em Gethen que confiava em mim, e o único getheniano de quem eu desconfiava. Ele tinha sido o único a me aceitar inteiramente como ser humano: que havia gostado de mim como pessoa, e me oferecera completa lealdade. E que, portanto, exigira de mim o mesmo grau de reconhecimento, de aceitação. Eu não estivera disposto a lhe oferecer isto. Tinha sentido medo de fazê-lo. Não queria oferecer minha confiança, minha amizade, a um homem que era mulher, uma mulher que era homem.

Constrangido, explicou simplesmente que estava no kemmer e tentava me evitar, na medida do possível. - Não devo tocá-lo - disse, com extremo embaraço; dizendo isto, virou o rosto.

- Entendo - respondi. - E concordo. (LE GUIN, 2005, p. 240)

A relação entre Genly e Estraven parece-se com muitas de romances sentimentais - cá estão o impedimento de se relacionarem (não mais de ordem familiar, como ser Montecchio, e sim ser de outro planeta); a impossibilidade do toque e da consumação da paixão, o sentimento aflorado e sufocado, que acaba no dramático sacrifício de Estraven, falecendo por Genly. Quem esperava da obra ideias e reflexões para além do binômio homens/mulheres parece que se frustrou - nada mais reacionário do que colocar a liberdade maravilhosa de seres ambissexuais dentro da heteronormatividade de um romance água com açúcar, que ensina como as mulheres devem se portar e conter seus desejos tanto sexuais quanto políticos.

Interessante esta intromissão do gênero do romance sentimental em uma obra que, até o momento, possuía como caráter central a discussão sobre o futuro do planeta Gethen, as possibilidades de uma outra história para aqueles alienígenas. A esta intromissão, que parece indevida, denomina-se aqui a força da tradição.

A intromissão do gênero sentimental e o fechamento da obra giram em torno da relação interpessoal Genly-Estraven - inclusive, o Enviado acaba frente a frente com o filho de Estraven, o que nele provocará sentimentos fortes, um "rapaz sisudo, impetuoso e provinciano, emudeceram-me por um instante" (LE GUIN, 2005, p. 290). Ou seja, em lugar de resolver as contradições ou dar uma pista sobre o futuro político-econômico de Gethen, Le Guin simplesmente termina o romance como uma história de amor e ainda insere um apêndice insosso (alvo, aliás, de muitas críticas de cientistas) sobre "o calendário e o relógio gethenianos" (LEM, 1971).

Aponta-se assim uma relação entre a impossibilidade da utopia e o aparecimento da discussão de gênero (gender) que estaciona por intermédio da forma. A reflexão sobre gênero no 
romance, que emerge do conteúdo representado, acaba apontando seu lado reacionário diante do ideal feminista - essa intromissão da tradição é possibilitada pela intermitência das formas e uso das descontinuidades de gênero.

Como continuar o conflito e finalmente configurar a utopia social econômica e também de equidade entre homens e mulheres ao mesmo tempo? A imaginação utópica estaciona, retrocede, não nos concede respostas. Apresenta uma história de amor impossível, gênero literário que reforça estereótipos de gênero e papéis sexuais. Ou seja, em lugar de auxiliar na formatação de uma utopia, a forma descontínua contribui para que o romance tenha um traço reacionário no que diz respeito ao feminismo. E, ainda, não nos concede uma resposta sobre como poderia ser uma utopia social. Caberiam estes dois ideais numa forma literária? Não sabemos. Contudo, o relevante é que esses desejos sigam emergindo para que se possa regressar e refletir: "Poderia existir algo para além disso".

Vistas por este prisma, o romance parece conter uma formulação que revela um desagradável montante de desejos irreconciliáveis e opostos que surgem da ordem social vigente: um desejo pueril por frear a roda da história em Gethen e por se permanecer ignorante sobre a ameaça do colonialismo interplanetário do Ekumen; um desejo por se relacionar com seres alienígenas que desconheceriam a opressão de gênero, relacionamento apenas possível pela ameaça da dominação. Nos dizeres de Jameson (2006a, p. 258), a ordem utópica parece ser uma estrutura maquiavélica de organização social e prática, oculta através da falsa universalidade dos diferentes regimes utópicos, que acaba por se dissolver no logro dos fantasmas das relações pessoais e em questões de ordem prática.

Estes desejos irreconciliáveis e opostos despontam no título ao romance, recortado de um verso bastante significativo no contexto da obra que traz um tema bastante complexo dentro da suposta liberdade sexual dos gethenianos e da utopia de gênero: o incesto. O trecho do verso que dá título ao romance, aparece em uma narrativa em primeira pessoa do getheniano Estraven, quando a Canção de Tormer é recitada ao Enviado Ai, no momento em que ambos peregrinam solitários pelo Gelo Gobrin e uma forte amizade florescente entre os dois. Estraven recita:

Luz é a mão esquerda da escuridão e escuridão, a mão direita da luz. 


\author{
Dois são um, vida e morte, unidas \\ como amantes no kemmer, \\ como mãos entrelaçadas, \\ como o caminho e a chegada. (LE GUIN, 2005, p. 224)
}

O narrador emociona-se muito e lembra que os versos constavam na carta de despedida de seu irmão antes de morrer, irmão com quem Estraven havia mantido uma relação incestuosa. Na obra, há uma repetição do tema sobre a impossibilidade do incesto - a regra de costume mais antiga era permitir o kemmerings (relacionamento) entre irmãos até o nascimento do primeiro filho:

Naquele tempo, como hoje, era permitido aos irmãos germanos permanecerem juntos como kemmerings até um deles gerar um filho; mas, depois disso, tinham de se separar; assim, nunca lhes era permitido jurar kemmering por toda a vida. (LE GUIN, 2005, p. 29)

Essas repetições são colocadas como parábolas, dentro da forma maior do romance, marcado pela descontinuidade de gêneros. Em uma delas, a mais expressiva e em que há a outra referência à "mão esquerda" seria o capítulo O lugar dentro da nevasca (retirado "de uma coleção de fitas de áudio das 'história de lares' do Karhide norte, dos arquivos da Faculdade de Historiadores de Erhenrang, narrador desconhecido"): um getheniano de nome Getheren, perdido no Gelo Pering, encontra o fantasma de seu irmão no meio de uma nevasca. O irmão havia cometido suicídio por não querer viver em outro kemmering a não ser com Getheren, com quem mantinha relação incestuosa. O fantasma consegue segurar o irmão amado pela mão esquerda. Getheren foge do fantasma do irmão, sobrevive à nevasca e "não sofreu nenhum dano permanente, exceto na mão esquerda, que estava congelada e precisou ser amputada”.

O tema do incesto como proibição, em uma civilização que gozaria de uma grande liberdade sexual, aparece assim como tabu em Gethen. A força da tradição desponta aqui mais uma vez. O surgimento do desejo entre irmãos e sua repetição no romance é curiosa, pois emerge como uma necessidade da existência de algum tipo de repressão - repressão em uma cultura, na qual, a princípio, isto pareceria impensável. Parece que não seria mais possível prever uma sociedade liberta da eterna frustração. A narrativa pune sua própria pulsão desejante, como se fosse impensável conseguir imaginar a felicidade que seria uma coletividade não seja atormentada pela questão do desejo. 
Segundo Jameson, parte da fascinação causada exercida pela obra de Le Guin deriva certamente do impulso subterrâneo que carrega em seu interior na direção de um "descanso" utópico, em direção a um "não lugar" supremo da coletividade não atormentada nem pelo sexo, nem pela história, sem superficialidades de objetos irrelevantes para a vida humana (JAMESON, 2006a, p. 332). Entretanto, não resistindo à estrutura maquiavélica da utopia, onde havia então um sonho por uma "sociedade melhor" (sem a divisão das pessoas em gênero e com grande liberdade sexual), emerge um traço típico da cultura dominante: a necessidade de repressão, seja pela proibição do incesto, seja pela proibição de se relacionar com espécies diferentes, que acaba por gerar a angústia existencial em Estraven, que é resolvida de forma melodramática pelo suicídio. Não se trata aqui de resolver este dilema da imaginação, que falha onde mais desejaria se desenvolver, ou de desanuviar suas tensões ou ainda de solucionar sua antinomia fundamental. Pelo contrário, se trata de produzir novas versões a estas tensões, novas proporções que perturbem as antigas e as atuais utopias e convertam a antinomia em si na estrutura central e no coração latente de própria utopia.

\subsection{Resignação e a emergência da solidariedade}

Durante muitos anos, Margaret Atwood relutou em considerar sua produção como ficção científica (após a entrada no século XXI, perde esta insistência), preferindo denominar sua obra como "ficção especulativa", com a justificativa de que, menos do que lidar com os limites tecnológicos e avanços da ciência, a construção com que trabalha teria a ver com um "pensar o futuro próximo". ${ }^{42}$ Desta ideia, é importante apontar sua candidatura a ter um parentesco com a dita literatura culta, cânone que inclusive estudou academicamente - esforço talvez mais evidente em sua obra poética, que muitas vezes faz releituras da mitologia grega, bem mais se aproximando

\footnotetext{
42 "If you're writing about the future and you aren't doing forecast journalism, you'll probably be writing something people will call either science fiction or speculative fiction. I like to make a distinction between science fiction proper and speculative fiction. For me, the science fiction label belongs on books with things in them that we can't yet do, such as going through a wormhole in space to another universe; and speculative fiction means a work that employs the means already to hand, such as DNA identification and credit cards, and that takes place on Planet Earth." (ATWOOD, 2005)
} 
destas tradições do que se afastando delas. ${ }^{43}$ Assim, embora estejamos no "vale-tudo" do balé das formas pós-modernas, Atwood atua dentro de um registro em que os gêneros literários com que trabalha estão inseridos em uma tradição - uma atitude bastante diferente da de Le Guin.

Também ao contrário do romance de Le Guin, em que o caráter político e social emerge da colagem de diferentes gêneros literários, HT apresenta um aspecto mais próximo do romance do alto modernismo neste quesito, pois o tema político do feminismo aparece ressaltado nos conteúdos literários com bastante insistência, seja no trabalho da linguagem, na configuração dos narradores, no espaço descrito. Aqui há uma clara obediência às “expectativas genéricas”. O propósito é narrar uma distopia feminista e isto é seguido com caráter programático.

Com relação às descontinuidades genéricas, em HT, temos uma grande ruptura entre narradores, que marcará a diferença entre a primeira e a segunda partes da obra. Não assistimos aqui à colagem entre narrativas curtas completamente diferentes (como ocorre em LHD) e melhor se configuram oscilações na narradora da primeira parte, a qual alterna digressões, pensamentos, fatos corriqueiros, tentativas de fuga, fragmentos que não possuem necessariamente ligação no enredo.

A descontinuidade de gêneros entre o relato testemunhal e o relatório acadêmico, evidenciada pela ruptura abrupta entre narradores possui, em HT, uma função similar à apresentada em LHD - atuar como um disfarce para as limitações na imaginação utópica. A diferença entre as técnicas estaria em como emerge a força da tradição de papeis de gênero em cada obra. Em LHD, a tradição emerge como um desvio imaginativo à questão utópica, que termina por não ser completada. Em HT, a tradição surge como ponto de partida para a configuração da distopia, respaldada pela resignação que atua como princípio de composição da obra dentro do espírito dos tempos de backlash.

Na primeira parte, apresenta-se um drama sem linearidade e, depois, um abrupto corte final, para dar início à estranha e curta segunda parte da obra. Na narração da Aia, explica-se a tragédia que a acometeu: perdeu toda a liberdade, direitos, e agora é uma serviçal sexual de uma ditadura teocrática. Longe de ter proporções épicas e arroubos, esta tragédia é contada em tom cotidiano, como se Offred estivesse acostumada a contextos sem esperanças, sem o "verdadeiro

\footnotetext{
${ }^{43}$ Análises podem ser lidas em DAVEY, 1984.
} 
caráter trágico". A resignação opera como princípio de composição. Não apenas como tema do romance, mas também como organizador da estrutura formal.

Nenhuma esperança. Sei onde estou, e quem sou, e que dia é hoje. Esses são os testes, e estou sã. A sanidade é um bem valioso; eu a amealho e guardo escondida como as pessoas antigamente amealhavam e escondiam dinheiro. Economizo sanidade, de maneira a vir a ter o suficiente, quando chegar a hora. (ATWOOD, 2006, p. 135)

Somado a este princípio, chama a atenção o uso do gênero testemunhal, cuja existência é explicada pelo narrador da segunda parte. Trata-se de uma forma bastante contemporânea, poderíamos dizer típica da segunda metade do século XX. Os testemunhos de pessoas comuns que vivenciaram fatos históricos ganharam destaque da opinião pública, motivados pelos movimentos de revisão de crimes humanitários e pela instauração de tribunais que visam a reconstituir crimes relacionados a direitos humanos, e os testemunhos acabam sendo parâmetros para a revisão dos fatos - aqui poderíamos apontar desde o julgamento de Eichmann, em que o próprio acusado testemunha, ${ }^{44}$ até a instauração das Comissões da Verdade, para investigar crimes das ditaduras latino-americanas, que fazem parte da ratificação das "transições democráticas" locais. Citando Beatriz Sarlo, que analisa o gênero e o impacto público dos testemunhos:

Os crimes das ditaduras foram exibidos em meio a florescimento de discursos testemunhais, sobretudo porque os julgamentos dos responsáveis (como no caso argentino) exigiram que muitas vítimas dessem seu testemunho como prova do que tinham sofrido e do que sabiam que outros sofreram até morrer. No âmbito judicial e nos meios de comunicação, a indispensável narração dos fatos não foi recebida com desconfiança sobre as possibilidades de reconstituir o passado, salvo pelos criminosos e seus representantes, que atacaram o valor probatório das narrações testemunhais, quando não as acusaram de ser falsas e encobrir os crimes da guerrilha. (SARLO, 2007, p. 46)

No conto da Aia propriamente dito, o texto adquire este estatuto de documento histórico ao ser enunciado pelo Prof. Pieixoto, que nos conta a fonte do relato, a fixação do áudio em fitas cassete e sua reconstituição, utilizando-se um método de pesquisa histórica que se assemelha às correntes atuais que valorizam a historiografia oral. Há um efeito de sentido interessante na utilização do gênero testemunhal, pois se presume que a memória seja preservada pela vivência da experiência:

\footnotetext{
${ }^{44}$ A obra canônica a respeito do julgamento é ARENDT, Hannah. Eichmann em Jerusalém. São Paulo: Companhia das Letras, 1999.
} 
O testemunho, por sua autorrepresentação como verdade de um sujeito que relata sua experiência, exige não ser submetido às regras que se aplicam a outros discursos de intenção referencial, alegando a verdade da experiência, quando não a do sofrimento, que é justamente a que deve ser examinada. (SARLO, 2007, p. 38)

O expediente de representar um testemunho do horror cria uma ilusão que provavelmente explica os impulsos de leitores que relatam terem "devorado o livro": gêneros testemunhais parecem garantir sentidos à experiência, ao mesmo tempo em que este sentido seja desmantelar a verdade de uma história maior. Entretanto, quando o relatório acadêmico faz a revelação de que tudo não passava de um testemunho reconstituído, é ambígua a relação entre o uso do gênero testemunhal e a posição do narrador: quem reconstitui é o próprio suspeito, muito ao contrário do ocorre nas Comissões da Verdade. Será que a reconstituição feita pelo odioso Prof. Pieixoto é fidedigna? A resignação opera no sentido de apagar a ideia de que "há uma verdade oculta a ser descoberta”, ou seja, o gênero testemunhal é utilizado beneficiando a dúvida sobre a verdade que apresenta, invertendo sua função política originária.

Outro gênero comentado pela crítica a HT seria o epistolar, berço do romance de língua inglesa, conhecido por ser destinado à educação sentimental das mulheres. ${ }^{45}$ As comparações com o gênero epistolar surgem, pois o relato da Aia fragmenta experiências, como se a cada dia descrevesse uma situação completamente diferente, narra suas vãs tentativas de permanecer fiel à sua cultura de mulher de classe média dos anos 1980 - ávida por revistas femininas que sobraram do expurgo e transformando o gesto de passar manteiga no rosto como hidratante em um ato de resistência cultural - não sendo insubordinada como a amiga Moira ou mesmo a mãe (cujos destinos não são nada animadores).

Aqui se revela uma função ideológica comum da tradição dos romances epistolares que está presente em HT: a vocação didática em prever e ensinar formas de comportamento adequado às mulheres dos anos de 1980. Em seu Pós-modernismo, Jameson irá apontar como, nas eras clássicas, as obras de arte eram imbuídas de funções didáticas e pedagógicas, principalmente em seu viés moralista. Após o modernismo, essa vocação se encontraria intimidada por razões históricas as quais se originam desde a valorização indevida do "gênio" burguês, tão em voga no alto modernismo, até intervenções partidárias no mundo das artes "revolucionárias" (JAMESON, 2006a, p. 76). No pós-modernismo, a cultura de massa acaba por assumir a tarefa de reinventar e fortalecer a hegemonia. Dessa forma, é importante se pensar nas dimensões didáticas e pedagógicas de uma

${ }^{45}$ A exemplo do citado Pamela, or virtue rewarded, de Richardson, publicada em 1740. 
literatura que, até então, pareceria engajada em criticar as condições sociais impostas às mulheres, como mencionado anteriormente. Assim, embora HT contenha uma forte carga de engajamento político, perfaz uma das vocações mais antigas ao gênero romanesco destinado às mulheres - que por ora vemos emprestado às telenovelas e séries de TV: auxiliar na sedimentação e na apreensão da ideologia, um entender os "como se portar", "como responder a estímulos emocionais", "como sentir".

Aqui se refere ao que Williams irá denominar de "processos de incorporação" - na consolidação das estruturas de sentimento, para utilizar termo do autor, haverá uma seleção elaborada historicamente para se definir o que sustentará a cultura dominante, no nosso caso prático, patriarcal:

(...) nós só podemos entender uma cultura dominante e efetiva se entendermos o processo social do qual ela depende: o processo de incorporação. Os modos de incorporação têm grande significado social. As instituições educacionais são geralmente os agentes principais na transmissão de uma cultura efetiva e dominante, e esta é, em nossos dias, uma atividade de grande importância, tanto econômica quanto cultural; de fato, é as duas coisas ao mesmo tempo. Além disso, num nível filosófico, no verdadeiro nível da teoria e no nível da história das várias práticas, há um processo que chamo de tradição seletiva: aquilo que, no interior dos termos de uma cultura dominante e efetiva, é sempre transmitido como "a tradição", "o passado importante". Mas o principal é sempre a seleção, o modo pelo qual, de um vasto campo de possibilidades do passado e do presente, certos significados e práticas são enfatizados e outros negligenciados e excluídos. (WILLIAMS, 2005, p. 217)

$\mathrm{Na}$ época da ascensão do romance burguês, esse aspecto dos processos de incorporação foi muito ligado à consolidação de valores patriarcais e atinge toda a linhagem de romances destinados ao público feminino. Aqueles romances retiravam do clamor por mudanças sociais a matéria literária que seria então reapresentada como arroubos sentimentais de relações interpessoais de cunho privado. Tais relações (que, por sua vez, guardam a reminiscência de um impulso subjacente por algum tipo de alteração no status quo) passarão por mil obstáculos, colocando-se a felicidade maior da mulher burguesa nas mãos de um homem comum, geralmente seu futuro marido, que a proverá com a responsabilidade por uma prole e por uma casa para transformar em lar. Resumida assim, parece uma narrativa pouco atraente e previsível, mas está entranhada ainda na maioria dos produtos culturais da cultura de massa, basta ligar a televisão, ir ao cinema, escutar canções recentes. Agora, em um século marcado pelas alterações nas relações de poder entre mulheres e homens (por exemplo, com a entrada maciça das mulheres de classe média no mercado 
de trabalho), mas com poucas modificações nas instituições fundamentais, seguindo vigentes a propriedade privada e a divisão em classes sociais, esta tarefa pedagógica de consolidação de valores patriarcais não é de somenos importância na produção cultural.

Em The handmaid's tale, para desespero das feministas mais críticas, a aia Offred ainda permanece à espera de um príncipe encantando que a retire daquela situação, colocando suas virtudes a salvo, como professaria Richardson às mulheres jovens do século XVIII, prosseguindo na melhor tradição dos romances epistolares didáticos endereçados a mulheres.

Exemplificando essas discussões com um trecho importante do romance, o final da primeira parte. Não se apresenta um desfecho exatamente dito para a história de Offred, esta parte termina subitamente quando a narradora é colocada em uma camionete, não sabendo se fugirá de Gilead ou será trucidada pelo regime ("e assim eu entro, embarco na escuridão ali dentro; ou então na luz"), não ficando claro se a caminhonete pertence a um grupo subversivo para salvar a Aia.

De qualquer forma, esta ação tem um homem por figura central: Nick. Ele habita a mesma casa, trabalha como motorista do Comandante. Até então, Offred, secretamente, o visita de noite, o que custaria a vida dos dois. Offred lhe disse seu verdadeiro nome e os dois mantém uma relação amorosa, embora não falem quase nada sobre o assunto, temendo a repressão. Neste episódio final, é Nick que aparece como um segurança e conduz a aia à caminhonete:

Espero um estranho, mas é Nick quem abre e empurra a porta, acende a luz. Não consigo situar isso, a menos que ele seja um deles. Sempre houve essa possibilidade. Nick, o Olho, investigador particular. Trabalho sujo é feito por gente suja.

Seu merda, penso. Abro minha boca para dizê-lo, mas ele avança, chega bem junto de mim e sussurra:

- Está tudo certo. É Mayday. Vá com eles. - Ele me chama por meu verdadeiro nome. Por que isso deveria significar alguma coisa?

- Eles? - digo. Vejo dois homens parados atrás dele, a luz acima no corredor transformando cabeças em caveiras. - Você deve estar louco. - Minha suspeita paira no ar acima dele, um anjo sombrio advertindo-me para não acreditar. Posso quase vê-lo. Por que não deveria ele saber da existência; eles a terão arrancado à força, espremendo, esmagando, retorcendo um número suficiente de corpos, um número suficiente de bocas a esta altura.

- Confie em mim - diz ele; o que por si só nunca foi um talismã, não traz nenhuma garantia. 
Mas eu agarro, esta oferta. É tudo o que ainda me resta. (ATWOOD, 2006, p. 346)

A crítica analisa o relacionamento da Aia com Nick de formas distintas. A vertente mais ingênua apontaria o amor como uma força subversiva. Concordar com este ponto de vista simplificado seria reforçar a lição hegemônica sem uma contestação maior do que essa subserviência poderia trazer. Prefere-se aqui a lucidez de Madonne Miner, que verifica um caráter reacionário nesta subserviência da Aia ao "amor" e ao colocar sua vida nas mãos de Nick, um príncipe salvador:

Instead, I argue that the novel subverts the subversive force of love, and that it raises serious questions about a man-woman axis, when this axis models itself upon patterns that restrict rather than liberate. In its representation of such patterns in relationships between Offred and Luke, Offred and the Commander, Offred and Nick, the novel insists upon love's limitations, rather than upon its latitudes. (MINER, 1991)

A solução formal de Atwood para a resolução do amor impossível entre Offred e Nick, seu possível príncipe-salvador, é menos radical do que o suicídio de Estraven por Genly em LHD. Contudo, da mesma forma, o relacionamento acaba de forma abrupta: esta parte do romance termina. O que esta quebra significaria? Parece que o princípio da resignação opera novamente, desta vez, com todos os ventos da força da tradição ao seu favor: que futuro imaginar para esta Aia fora de Gilead? Seria uma feliz exilada em outro país, com suas revistas femininas e hidratantes? Tornaria clara, por fim, sua ideologia liberal - uma vez assegurados a liberdade e o poder de consumo, as condições sociais restantes são bastante toleráveis, mais do que isso, desejáveis, não é mesmo?

Indo além à crítica de Miner, aponta-se, nesta passagem, uma emergência utópica em um romance de completo fechamento distópico: a solidariedade. Não seria esta solidariedade entre o motorista e aia que teria motivado essa subversão? Mais do que o amor, não seria a solidariedade que faria existir uma organização complexa (como seria possivelmente a Mayday) para retirar as mulheres férteis de Gilead? Observe-se que o motorista Nick também é um subordinado, não tendo os privilégios de homens como os Comandantes, se vislumbra uma identificação motivada pela opressão por classe social e não exatamente pela distinção entre homens e mulheres. Aqui, utilizando-se a metodologia de Jameson, se apresenta um acréscimo à interpretação mais conhecida de HT: aponta-se a emergência de valores que transcendem a cultura dominante, ocorrências que passam pelas frestas das formas literárias conservadoras que conformam o romance. Obras da 
cultura de massa contém uma dimensão utópica e assim, além da questão de gênero, que acaba sendo sufocada em HT, no melhor espírito sombrio dos tempos de backlash, a chama da esperança por uma ligação coletiva que transcenda o capitalismo é acendida. Entretanto, mal nomeada, desaparece, não se sustenta, provavelmente por não existir ainda uma experiência histórica que ajude a vislumbrar o que seria essa transcendência. A narrativa é interrompida, tem-se o final da primeira parte. 


\section{Capítulo 6: Considerações finais}

Embora a utopia a respeito da questão de gênero seja a questão candente em ambos os romances, a imaginação utópica apresenta limitações no momento em que esta utopia é apresentada - no vocabulário de Jameson, a ordem utópica padece com sua estrutura maquiavélica (JAMESON, 2006a, p. 258), incapaz de permanecer unívoca e não se dissolver ante as configurações atuais das relações pessoais e de organização social. Ocorreria, em cada um dos romances, uma dupla capitulação: seja no plano da utopia política, seja no plano da utopia feminista. Os dois livros não conseguiriam apontar, enquanto representação, o que poderia ser a sociedade atual alémcapitalismo, além-patriarcado. As obras sublinham a incapacidade dos tempos presentes em imaginar outras formas de organização social, principalmente de concatenar os dois anseios: a mudança sobre justiça econômica e justiça de gênero.

Em LHD, essa capitulação ocorre no plano das formas, em que se empresta várias formas e soluções ao enredo típicas de romances tradicionais para mulheres, e ocorre ainda no plano dos materiais acomodados na foram romance, em que a configuração de seres ambissexuais, que estariam libertos supostamente da violência sexual e de não satisfazerem seus desejos, sejam punidos pelo tabu do incesto, como se fosse insuportável imaginar um mundo de desejo pleno -bém se mencione novamente a dependência imaginativa do modelo heteronormativo, inter-relacionado com aspectos biológicos. Entretanto, o romance mostra o embate entre civilizações com meios de produção distintos - os colonizadores hainianos, os burocratas de Orgoryen e os medievais harhideanos - mesmo que a obra não apresente respostas às perguntas que não podemos formular, aponta o impulso subterrâneo para uma vontade de se atingir o "descanso" utópico, de uma coletividade não atormentada nem pelo sexo, nem pela história (JAMESON, 2006a, p. 332).

Margaret Atwood, por sua vez, não se propõe a representar uma utopia. Em HT, não se consegue vislumbrar qualquer outra ordem social possível além do capitalismo, com destaque à economia de guerra, e do patriarcado fortalecido em um estado teocrático, em grande sintonia com o espírito do backlash, que se abate nos anos de 1980, mitigando consideravelmente as conquistas feministas, fenômeno que aparece conjugado com a derrocada do bloco soviético e fortalecimento do neoliberalismo. Pode-se dizer que a função ideológica de HT é colocar em discussão as 
possibilidades de mudança que a questão de gênero trouxe às relações sociais na segunda metade do século XX, embora o processo de incorporação desta questão acabe, em última análise, dialogando com a ideologia mais tradicional, reafirmando a cultura dominante resignadamente. $\mathrm{O}$ caráter didático do romance surge em sua vertente mais conservadora: absorvendo as demandas políticas feministas e apresentando, uma vez mais, as velhas respostas de relacionamentos patriarcais, realizando o fechamento utópico. O interessante da obra é a emergência do valor da solidariedade entre a aia e o motorista - solidariedade que parece despontar para superar a opressão de classe social - o que sugere que, mesmo nos best sellers mais vendidos, ainda pulsa um desejo por transcender o que se conhece hoje por única alternativa.

A impossibilidade de configuração de utopias não se trata somente de uma falha intrínseca das obras: o horizonte histórico não aponta hoje um caminho real e unívoco que possa oferecer uma via de transcendência ao que se apresenta. O grande motivo de estudo ser realizado é apontar nos romances, sem os retirar da condição de produto da cultura de massa, seus fracassos imaginativos e novamente receber o mundo como realmente se apresenta para que novas utopias, mesmo que fracassem, possam ser acalentadas. 


\section{Bibliografia}

ADORNO, Theodor W.; HORKHEIMER, Max. A dialética do esclarecimento: fragmentos filosóficos. Rio de Janeiro: Jorge Zahar, 2011.

ADORNO, Theodor W. Notas de literatura. Tomo I. São Paulo: Duas Cidades, 34, 2003.

ADORNO, Theodor; BENJAMIN, Walter; BLOCH, Ernst; BRECHT, Bertold; LUKÁCS, Georg. Aesthetics and politics. London: Verso, 2007.

AMARAL, Adriana. Visões perigosas: uma arque-genealogia do cyberpunk. Porto Alegre: Sulina, 2006.

ANDERSON, Perry. A Crise da Crise do Marxismo: introdução a um debate contemporâneo. São Paulo: Brasiliense, 1987.

ANDERSON, Perry. Arguments within western marxism. London: Verso, 1980.

ANDERSON, Perry. As origens da pós-modernidade. Rio de Janeiro: Jorge Zahar, 1999.

ANDERSON, Perry. Considerações sobre o marxismo ocidental. São Paulo: Brasiliense, 1989.

ANDERSON, Perry. The Left in the fifties. New Left Review, n. 29, p. 3-18,1965.

ARNOLD, Matthew. Culture and anarchy and other writings. Cambridge:

Cambridge University, 1993.

ATTEBERY, Brian. Decoding Gender in Science Fiction. New York: Rutledge, 2002. P. 131 .

ATWOOD, Margaret. Negotiating with the dead: a writer on writing. Cambridge: Cambridge University, 2002. 
ATWOOD, Margaret. O Conto da Aia. Trad. Ana Deiró. São Paulo: Rocco, 2006.

ATWOOD, Margaret. Selected Poems: 1966-1984. Oxford: Oxford University, 1990.

ATWOOD, Margaret. Survival: a thematic guide to canadian literature. Toronto: Anansi, 1972. Republicado em 2012.

ATWOOD, Margaret. Wandering Wenda and Widow Wallop's Wunderground Washery. Toronto: McArthur \& Co., 2011.

ATWOOD, Margaret. Wilderness Tips. Toronto: McClelland \& Stewart, 1991.

AUERBACH, Erich. Mimesis: the representation of reality in western literature. Princeton: Princeton University, 2003.

BADDELEY, Gavin. Goth Chic: um guia para a cultura dark. Rio de Janeiro: Rocco, 2005.

BAKHTIN, Mikhail. The dialogic imagination: four essays. Austin: University of Texas, 1992.

BARBOUR, Douglas. Wholeness and Balance in the Hainish Novels of Ursula K. Le Guin. Science Fiction Studies 1.3, p. 164-73, 1974. Disponível em: http://www.depauw.edu/sfs/backissues/3/barbour3art.htm. Acesso em: 14 de dez. 2014.

BAUDRILLARD, Jean. A transparência do mal: ensaios sobre os fenômenos extremos. Campinas: Papirus, 1990.

BELL, Daniel. The end of ideology: on the exhaustion of political ideas in the fifties. New York: Macmillan,1961.

BENJAMIN, Walter. Obras escolhidas: magia e técnica, arte e política. São Paulo, Brasiliense, 1993. $6^{\mathrm{a}}$ edição.

BENJAMIN, Walter. Understanding Brecht. London: New Left Books, 1973. 
BICKMAN, Martin. Le Guin's The Left Hand of Darkness: Form and Content. Science Fiction Studies 4.1, p. 42-47, 1977. Disponível em http://www.depauw.edu/sfs/backissues/11/bickman11.htm. Acesso em: 14 de dez. 2014. BOLTANSKI, Luc; CHIAPELLO, Ève. The new spirit of capitalism. London: Verso, 2005.

BOUDON, Raymond. A ideologia: ou a origem das ideias recebidas. São Paulo: Ática, 1989.

BROOKS, Cleanth. The well wrought urn: studies in the structure of poetry. New York: Harcourt, Brace, 1947.

BUHLE, Paul. Marxism in the United States: remapping the history of american Left. London: Verso, 1987.

BUTLER, Judith. Problemas de gênero: feminismo e subversão da identidade. Trad. Renato Aguiar. Rio de Janeiro: Civilização Brasileira, 2003.

BUTLER, Judith. Undoing gender. Nova York: Routledge, 2004.

CALLAWAY, Alanna. Women disunited : Margaret Atwood's The handmaid's tale as a critique of feminism. Master Theses, San Jose State University, 2008. Disponível em http://scholarworks.sjsu.edu/cgi/viewcontent.cgi?article=4501\&context=etd_theses. Acesso em 14 dez. 2014.

CAMEPELLO, Eliane, O Kunstlerroman de autoria feminina - a poética da artista em Atwood, Tyler, Pinon e Valenzuela, Rio Grande: FURG, 2003.

CANDIDO, Antonio. Crítica e Sociologia. In: Literatura e Sociedade. Rio de Janeiro: Ouro sobre Azul, 2006.

CARNEIRO, André. Introdução ao estudo da "science fiction". São Paulo: Scorpio, 2004.

CARVER, Raymond. Short Cuts. New York: Vintage, 1993. 
CARVER, Terrell. (ed.). The Cambridge companion to Marx. Cambridge: Cambridge University, 1995.

CAUSO, Roberto de Sousa. Ficção científica, fantasia e horror no Brasil: 1875 a 1950. Belo Horizonte: UFMG, 2003.

CEVASCO, Maria Elisa B. P. S. (org). A cultura do dinheiro: ensaios sobre a globalização. Petrópolis: Vozes, 2001.

CEVASCO, Maria Elisa B. P. S. Dez Lições de Estudos Culturais. São Paulo: Boitempo, 2003.

CEVASCO, Maria Elisa B. P. S. E agora? O que ainda pode fazer a crítica cultural empenhada? Crítica Marxista (São Paulo), v. 1, p. 129-140, 2006.

CEVASCO, Maria Elisa B. P. S. Momentos da crítica cultural materialista. In: Terceira Margem. Revista do Programa de Pós-Graduação em Ciência da Literatura. Rio de Janeiro, ano IX, n. 12, 2005. Disponível em:

http://www.ciencialit.letras.ufrj.br/terceiramargemonline/numero12/sumario.html. Acesso em: 13 de dez. 2014.

CEVASCO, Maria Elisa B. P. S. Para ler Raymond Williams. São Paulo: Paz e Terra, 2001 .

CLEMESHA, Arlene. O que está acontecendo? São Paulo: Instituto de Estudos Avançados da Universidade de São Paulo, 2013. Debate público realizado na Sala de Eventos do Instituto, em 21 de junho de 2013 e transmitido ao vivo pelo site do Instituto. Conteúdo indisponível.

COHEN, Monica. Professional domesticity in the Victorian novel: women, work and home. Cambridge: CUP, 1998.

COOKE, Nathalie. Margaret Atwood: A Critical Companion, Greenwood Press, Westport, 2004. 
COOKE, Nathalie. Margaret Atwood: A Critical Companion. Westport: Greenwood, 2004;

CORREA, Mariza. Do feminismo aos estudos de gênero no Brasil: um exemplo pessoal. Cadernos Pagu. Campinas, n. 16, 2001. Disponível em: http://www.scielo.br/scielo.php?script=sci_arttext\&pid=S0104$83332001000100002 \& \operatorname{lng}=$ en\&nrm=iso. Acesso em: 14 de dez. 2014.

COSTA, Claudia de Lima e ÁVILA, Eliana. Gloria Anzaldúa, a consciência mestiça e o "feminismo da diferença". Revista Estudos Feministas. Florianópolis, vol. 13, n. 3, set.-dez. 2005. Disponível em: http://dx.doi.org/10.1590/S0104-026X2005000300014. Acesso em: 14 de dez. 1014.

COSTA, Claudia de Lima. O leito de Procusto: gênero, linguagem e as teorias feministas. In: Cadernos Pagu. Campinas, n. 2, p. 141-174, 1994.

COSTA, Iná Camargo. Panorama do Rio Vermelho: ensaios sobre o teatro americano moderno. São Paulo: Nankin, 2001.

CUNHA, Fausto. A ficção científica no Brasil. In: ALLEN, L. David. No mundo da ficção científica. Trad. Antonio Alexandre Faccioli e Gregório Pelegi Toloy. São Paulo: Summus, 1974.

DAMASCO, Mariana Santos; MAIO, Marcos Chor; MONTEIRO, Simone. Feminismo negro: raça, identidade e saúde reprodutiva no Brasil (1975-1993). Revista Estudos Feministas. Florianópolis, vol. 20, n. 1, jan.-abr. 2012. Disponível em: http://www.scielo.br/scielo.php?script=sci_arttext\&pid=S0104026X2012000100008\&lng=en\&nrm=iso. Acesso em: 14 de dez. 2014.

DAVEY, Frank. Margaret Atwood: a feminist poetics. Vancouver: Talonbooks, 1984.

DAVIDOFF, Leonore; HALL, Catherine. Family fortunes: men and women of the English middle-classes, 1780-1850. London: Routledge, 1987. 
DAVIDSON, Arnold E. Future Tense: making history in The handmaid's tale. In: CASTRO, Jan Garden; SPANCKEREN, Kathryn van. Margaret Atwood: vision and forms. Carbondale: Southern Illinois University, 1988.

DAVIS, Mike. Prisoners of the american dream: politics and economy in the history of the U.S. working class. London: Verso, 1990.

DEBORD, Guy. A sociedade do espetáculo. Rio de Janeiro: Contraponto, 1997.

DELAMONT, Sara e DUFFIN, Lorna (eds.). The nineteenth-century woman: her cultural and physical world. London: Croom Helm, 1976.

DENNING, Michael. The cultural front: the laboring of American culture in the twentieth century. London: Verso, 1997.

DUPLESSIS, Rachel. Writing Beyond the Ending: Narrative Strategies of TwentiethCentury Women Writers (Everywoman.), Indiana Univ, 1985.

DWORKIN, Andrea. Pornography: men possessing women. Plume, 1991.

EAGLETON, Terry. Marxism and literary criticism. Berkeley: University of California, 1976.

EAGLETON, Terry. Raymond Williams: critical perspectives. London: Polity, 1989.

EAGLETON, Terry. The English novel: an introduction. Oxford: Blackwell, 2005.

FALUDI, Susan. Backlash: the undeclared war against American women. Nova Iorque: Anchor Books, 1992.

FEHER, Ferenc. O romance está morrendo? São Paulo: Paz e Terra, 1997.

FELINTO, Erick. A religião das máquinas: ensaios sobre o imaginário da cibercultura. Porto Alegre: Sulina, 2005.

FERNANDES, Fábio. A construção do imaginário cyber: William Gibson, criador da cibercultura. São Paulo: Anhembi Morumbi, 2006. 
FERNANDES, Fábio. Arthur C. Clarke e William Gibson: visões da aldeia global de McLuhan no futuro próximo. Revista GHREBH: São Paulo, mar. 2003. Disponível em: http://revista.cisc.org.br/ghrebh2/artigos/02fabiofernandes032003.html. Acesso em: 14 de dez. 2014.

FITTING, Peter. "So We All Became Mothers": New Roles for Men in Recent Utopian Fiction. Science Fiction Studies 12.2, 1985. Disponível em http://www.jstor.org/stable/4239682. Acesso em: 14 de dez. 2014.

FRANZEN, Niklas e RÜSCHE, Ana. Movimentos portadores de uma nova cultura política - os novos movimentos sociais e as novas formas de resistência na América Latina. Disponível em http://www.rosaluxspba.org/2014/09/movimentos-portadores-deuma-nova-cultura-politica. Acesso em: 14 de dez. 2014.

FRASER, Nancy. From redistribution to recognition? Dilemmas of justice in a 'postsocialist' age. New Left Review, n. 212, p. 68-93, July/August. 1995.

FRASER, Nancy. O Feminismo, o capitalismo e a astúcia da história. Revista Mediações. Londrina, vol. 14, n. 2, 2009.

FRASER, Nancy. Reconhecimento sem ética? In: Lua Nova, São Paulo, 70: p. 101138, 2007.

FREDERICO, Carlos. A sociologia da literatura de Lucien Goldmann. Revista Estudos Avançados. São Paulo, vol. 19, n. 54, p. 429-446, 2005. Disponível em http://www.scielo.br/pdf/ea/v19n54/21.pdf. Acesso em 14 de dez. 2014.

FREUD, Sigmund. (1919). O ‘estranho’. In: Edição Standard Brasileira das Obras Completas de Sigmund Freud. Rio de Janeiro: Imago, Vol. XVII, 1996.

FREUD, Sigmund. (1924). A dissolução do complexo de Édipo. In: Obras Completas, vol. 16: O Eu e o Id e outros textos (1923-1925). São Paulo: Companhia das Letras, 2011. 
FREUD, Sigmund. (1925). Algumas consequências psíquicas da diferença anatômica entre os sexos. In: Obras Completas, vol. 16: O Eu e o Id e outros textos (1923-1925). São Paulo: Companhia das Letras, 2011.

FRYE, Northrop. Anatomy of criticism: four essays. Princeton: Princeton University, 1973.

GINWAY, M. Elizabeth. Ficção científica brasileira: mitos culturais e nacionalidade no país do futuro. São Paulo: Devir, 2005.

GONÇALVES, Eliane; PINTO, Joana Plaza. Reflexões e problemas da "transmissão" intergeracional no feminismo brasileiro. Cadernos. Pagu. Campinas, n. 36, jun. 2011. Disponível em: http://www.scielo.br/scielo.php?script=sci_arttext\&pid=S0104$83332011000100003 \& \operatorname{lng}=e n \& n r m=$ iso. Acesso em 14 de jun. 2014.

GORDON, Joel. Turning Pages: The Life and Literature of Margaret Atwood. VFormation Productions, 2007.

HARAWAY, Donna. Gênero para um dicionário marxista: a política sexual de uma palavra. In: Cadernos Pagu. Campinas, n. 22, p.201-246, 2004.

HARDT, M. and WEEKS, K. (eds.). The Jameson reader. Oxford: Blackwell, 2000.

HARVEY, David. A companion to Marx's Capital. London: Verso, 2010.

HARVEY, David. A condição pós-moderna: uma pesquisa sobre as origens da mudança cultural. São Paulo: Loyola, 2006.

HAUG, W. Crítica da Estética da Mercadoria. São Paulo: Unesp, 1996.

HAUSER, A. História social da arte e da literatura. São Paulo: Martins Fontes, 2000.

HAYLES, N. Katherine. How we became posthuman: virtual bodies in cybernetics, literature and informatics. Chicago: University of Chicago, 1999. 
HEMMINGS, Clare, Telling feminist stories - Contando estórias feministas. In: Revista Estudos Feministas, vol.17 no.1 Florianópolis, Jan./Apr. 2009. Disponível em http://dx.doi.org/10.1590/S0104-026X2009000100012. Acesso em: 14 de dez. 2014.

HEMMINGS, Clare. Telling feminist stories: contando estórias feministas. In: Revista Estudos Feministas. Florianópolis, vol. 17, no. 1., jan.-abr. 2009. Disponível em: http://dx.doi.org/10.1590/S0104-026X2009000100012. Acesso em 14 de dez. 2014.

HEMMINGS, Clare. Why Stories Matter: the political grammar of feminist theory. Durham: Duke University, 2011.

HOBSBAWM, Eric. A era das revoluções: 1789-1848. Rio de Janeiro, Paz e Terra, 1977.

Hobsbawm, Eric. A era dos extremos: o breve século XX - 1914-1991. São Paulo: Companhia das Letras, 2012.

Hobsbawm, Eric. Como mudar o mundo: Marx e o marxismo, 1840-2011. São Paulo: Companhia das Letras, 2011.

HOSSNE, Andrea Saad. Bovarismo e romance: Madame Bovary e Lady Oracle, São Paulo, Ateliê, 2000.

HOWELLS, Coral Ann. Margaret Atwood, Londres: Palgrave Macmillan, 2005.

HOWELLS, Coral Ann. The Cambridge Companion to Margaret Atwood, Cambridge: Cambridge UP, 2006.

HUNTINGTON, John. Public and Private Imperatives in Le Guin's Novels. Science Fiction Studies 2.3, p. 237-243, 1975. Disponível em http://www.depauw.edu/sfs/backissues/7/huntington7art.htm. Acesso em: 14 de dez. 2014.

INGERSOLL, Earl (org.). Waltzing Again: new and selected conversations with Margaret Atwood. Princeton: Ontario Review, 2006. 
INGERSOLL, Earl G., Margaret Atwood: Conversations. Princeton, New Jersey: Ontario Review, 1990.

INGHAM, Patricia. The language of gender and class: transformation in the Victorian novel. London: Routledge, 1996.

JAMESON, Fredric. (a) Pós-modernismo: a lógica cultural do capitalismo tardio. Trad. Maria Elisa Cevasco. São Paulo: Ática, 2006.

JAMESON, Fredric. (a) The geopolitical aesthetic: cinema and space in the world system. Bloomington, Indiana: Indiana University, 1992; London: British Film Institute, 1992.

JAMESON, Fredric. (b) A virada cultural: reflexões sobre o pós-modernismo. Rio de Janeiro: Civilização brasileira, 2006.

JAMESON, Fredric. (b) Signatures of the Visible. New York: Routledge, 1992.

JAMESON, Fredric. Archaeologies of the future: the desire called utopia and other science fictions. London: Verso, 2005.

JAMESON, Fredric. As Sementes do Tempo. São Paulo: Ática, 1997.

JAMESON, Fredric. Brecht and method. London: Verso, 1998.

JAMESON, Fredric. Generic Discontinuities in SF: Brian Aldiss' Starship. In: Science Fiction Studies. Greencastle, IN, vol. 1, n. 2, parte 2, outono 1973. Disponível em: http://www.depauw.edu/sfs/backissues/2/jameson2art.htm. Acesso em: 14 de dez. 2014. JAMESON, Fredric. Late Marxism: Adorno, or, the persistence of the dialectic. London: Verso, 1990.

JAMESON, Fredric. Marxism and form: twentieth-century dialectical theories of literature. Princeton: Princeton University, 1971.

JAMESON, Fredric. O inconsciente político. São Paulo: Ática, 1999. 
JAMESON, Fredric. Pós-modernidade e sociedade de consumo. Trad. Vinicius Dantas. In: Novos Estudos. CEBRAP. São Paulo, n. 12, p. 16-26, jun. 1985. Disponível em: http://pt.scribd.com/doc/53755636/Fredric-Jameson-Pos-modernidade-e-sociedadede-consumo. Acesso em: 14 de dez. 2014.

JAMESON, Fredric. Reificação e utopia na cultura de massa. In: Crítica Marxista. São Paulo, vol. 1, n. 1, p. 1-26, 1994. Disponível em: http://www.ifch.unicamp.br/criticamarxista/arquivos_biblioteca/CM_1.2.pdf. Acesso em: 14 de dez. 2014.

JAMESON, Fredric. The ideologies of theory: essays, 1971-1986. London: Verso, 2008. 679 p.

JAMESON, Fredric. Then you are them. In: London Review of Books. London, n. 17, vol. 31, 10 set. 2009. Disponível em: http://www.lrb.co.uk/v31/n17/fredricjameson/then-you-are-them. Acesso em: 13 de dez. 2014.

JAMESON, Fredric. World reduction in Le Guin: the emergence of utopian narrative. In: Science Fiction Studies. Greencastle, IN, n. 7, vol. 2, parte 3, nov. 1975. Disponível em: https://www.depauw.edu/sfs/backissues/7/jameson7art.htm. Acesso em: 13 de dez. 2014.

KOLLER, Sílvia Helena; NARVAZ, Martha Giudice. Metodologias feministas e estudos de gênero: articulando pesquisa, clínica e política. In: Psicologia em estudo. Maringá, vol. 11, n. 3, p. 647-654, set.-dez. 2006.

KONDER, Leandro. A questão da ideologia. São Paulo: Companhia das Letras, 2002. KONDER, Leandro. Introdução: uma nova teoria do romance. In: FEHER, Ferenc. $O$ romance está morrendo? São Paulo: Paz e Terra, 1997.

KURZ, Robert. O Colapso da Modernização: da derrocada do socialismo de caserna à crise da economia mundial. Trad. Karen Elsabe Barbosa. São Paulo: Paz e Terra, 2004.

LACAN, Jacques. Escritos. Rio de Janeiro: Jorge Zahar, 1998. 
LE GUIN, Ursula K. Is Gender Necessary? In: The Language of the Night: Essays on Fantasy and Science Fiction. New York: G.P. Putnam’s Sons, p. 161-169, 1979.

LE GUIN, Ursula K. Is Gender Necessary? Redux. In Dancing at the Edge of the World: Thoughts on Words, Women, Places. New York: Grove Press: p. 7-16, 1989.

LE GUIN, Ursula K. Re: Lost Opportunities, SF Commentary, 26, p. 90-93, 1972.

LE GUIN, Ursula. A Mão esquerda da Escuridão. Trad. Susana Alexandria. São Paulo: Aleph, 2005.

LEAVIS, Frank R. For continuity. Cambridge: Minority, 1933.

LEFANU, Sarah. Ursula K. Le Guin. In: Feminism and Science Fiction. Bloomington: Indiana UP, p. 130-146, 1989.

LEM, Stanislaw. Lost Opportunities. In: SF Commentary. Melbourne, n. 24, nov. 1971.

LEMOS, André. Cibercultura: tecnologia e vida social na cultura contemporânea. Porto Alegre: Sulina, 2002.

LODGE, David. (ed.). 20th century literary criticism: a reader. London: Longman, 1972.

LODGE, David. A linguagem da ficção modernista. In: BRADBURY, Malcolm; MCFARLANE, James. Guia geral do Modernismo. São Paulo: Schwarcz, 1999. LUKÁCS, Georg. A teoria do romance: um ensaio histórico-filosófico sobre as formas da grande épica. São Paulo: Duas Cidades; Editora 34, 2000.

LUKÁCS, Georg. History and class consciousness. Trans. Rodney Livingstone. Cambridge, Massachusetts: MIT, 1971.

MARCUSE, Herbert. Eros e civilização, Rio de Janeiro, Zahar, 1975. 
MARX, Karl.; ENGELS, Friedrich. Collected Works. 50 volumes. New York: International Publishers, 1975-2005.

McCCOMBS, Judit (org). Critical Essays on Margaret Atwood, G. K. Hall \& Co., Boston, 1988.

McCCOMBS, Judit (org). Critical Essays on Margaret Atwood. Boston: G. K. Hall, 1988.

McLUHAN, Marshall. Os meios de comunicação como extensões do homem. São Paulo: Cultrix, 1969.

McLUHAN, Marshall; POWERS, Bruce R. The global village: transformations in world life and media in the 21st century. New York: Oxford University, 1989.

McWHORTER, Carrie B. Brandishing shifgrethor: LeGuin's "The left hand of darkness". In: Notes on Contemporary Literature. West Georgia College. Carrollton, GA, n. 28, jan., 1998.

MINER, Madonne. "Trust Me": reading the romance plot in Margaret Atwood's The handmaid's tale. In: Twentieth Century Literature. Hofstra University. Hempstead, NY, vol. 37, n. 2, pp. 148-168, verão 1991. Disponível em: http://www.jstor.org/stable/441844. Acesso em: 14 de dez. 2014.

MINER, Madonne. "Trust Me": Reading the Romance Plot in Margaret Atwood's The Handmaid's. In: Twentieth Century Literature, Hofstra University, Vol. 37, p. 148168, 1991. Disponível em http://www.jstor.org/stable/441844. Acesso em 14 dez. 2014. MITCHELL, Juliet e OAKLEY, Ann. Who's afraid of feminism? Seeing through the backlash. New York: The New York Press, 1997.

MORETTI, Franco. Atlas of the European novel: 1800-1900. London, Verso, 1999. MORGAN, Ellen. The Feminist Novel of Androgynous Fantasy. Frontiers: A Journal of Women Studies 2.3, p. 40-49, 1977. 
MORRISON, Sarah. Mothering Desire: The Romance Plot in Margaret Atwood's The Handmaid's Tale and Susan Fromberg Schaeffer's The Madness of a Seduced Woman. In: Tulsa Studies in Women's Literature, Vol. 19, No. 2, p. 315-336, 2000. Disponível em http://www.jstor.org/stable/464432. Acesso em 14 dez. 2014.

MURPHY Patrick D. The Left Hand of Fabulation: The Poetry of Ursula K. Le Guin. In: The Poetic Fantastic: Studies in an Evolving Genre. Eds. Patrick D. Murphy and Vernon Ross Hyles. Westport: Greenwood, p. 123-36, 1989.

NEUMAN, Shirley. 'Just a Backlash': Margaret Atwood, Feminism, and The Handmaid's Tale. University of Toronto Quarterly 75.3, p. 857-868, 2006. Disponível em http://mpenglish.pbworks.com/f/HT+-+Historical.pdf. Acesso em 14 dez. 2014.

NISCHIK, Reingard M (org). Margaret Atwood: Works and Impact. Toronto: House of Anansi Press, 2002.

NISCHIK, Reingard M. (org.). Engendering Genre: The Works of Margaret Atwood. Ottawa: University of Ottawa, 2009.

NISCHIK, Reingard M. (org.). Margaret Atwood: Works and Impact. Toronto: House of Anansi, 2002.

NOLAN, Fiona. Feminist Utopias and Questions of Liberty: Margaret Atwood's The Handmaid's Tale as Critique of Second Wave Feminism. In: Women: A Cultural Review, p. 18-32, 2005.

NOLASCO, Edgar Cézar; LONDERO, Rodolfo Rorato (orgs.). Volta ao mundo da ficção científica. Campo Grande: UFMS, 2007.

NUDELMAN, Rafail. Approach to the Structure of Le Guin's SF: basic to Le Guin's SF. In: Science Fiction Studies. Greencastle, IN, vol. 2, n. 7, parte 3, nov. 1975. Disponível em http://www.depauw.edu/sfs/backissues/7/nudelman7art.htm. Acesso em: 14 de dez. 2014.

OLIVEIRA, Marluce de Freitas, Unmasking The Tale: Margaret Atwood's The Handmaid's Tale. Dissertação defendida em 2002, UFMG. 
PALMER, D. J. The rise of English studies: an account of the study of English language and literature from its origin. London: Oxford University, 1965.

PEEL, Ellen. Black and White and Read All Over: The Semiotics of Difference and Chiaroscuro in Le Guin's Left Hand of Darkness. In: Semiotics Around the World: Synthesis in Diversity. Eds. Irmengard Rauch and Gerald F. Carr. Berlin: Mouton de Gruyter, p. 453-56, 1997.

PEEL, Ellen. Politics, Persuasion and Pragmatism: A Rhetoric of Feminist Utopian Fiction. Columbus, OH: Ohio State UP, p. 109-149, 2002.

PEEL, Ellen. Reading piebald patterns in Le Guin's The Left Hand of Darkness. In: Women of Other Worlds: Excursions through Science Fiction and Feminism. Eds. Helen Merrick and Tess Williams. Nedlands, AU: University of Western Australia Press, p. 3140, 1999.

PISCITELLI, Adriana. Re-criando a (categoria) mulher? In: ALGRANTI, Leila (org.). A prática feminista e o conceito de gênero. Campinas: IFCH-Unicamp, 2002. Disponível em: http://www.scielo.br/pdf/cpa/n22/n22a09.pdf. Acesso em 14 de dez. 2014.

POOVEY, Mary. Uneven developments: the ideological work of gender in midVictorian England. University of Chicago, 1988.

PRINS, Baukje; MEIJER, Irene Costera. Como os corpos se tornam matéria: entrevista com Judith Butler. Revista Estudos Feministas. Florianópolis, vol. 10, n. 1, pp. 155-167, jan. 2002. ISSN 0104-026X. Disponível em: http://dx.doi.org/10.1590/S0104-026X2002000100009. Acesso em: 14 de dez. 2014. REYNOLDS, Margaret. Margaret Atwood: The Essential Guide to Contemporary Literature, London: Vintage, 2002.

REYNOLDS, Margaret. Margaret Atwood: The Essential Guide to Contemporary Literature. Londres: Vintage, 2002.

ROSENFELD, Anatol. Teatro épico. São Paulo: Perspectiva, 2001. 
RUBIN, Gayle. (a) Thinking sex: notes for a radical theory of the politics of sexuality. In: REITER, Rayna (ed.). Toward an anthropology of women, New York: Monthly Review, 1975.

RUBIN, Gayle. (b) The traffic in women: notes on the political economy of sex. In: REITER, Rayna Rapp. (ed.) Toward an anthropology of women. New York, Monthly Review, 1975.

RUSHOWY, Kristin. School board says it's taking complaint about book seriously. Toronto Star Newspaper, Toronto, 17 jan. 2009. Disponível em: http://www.thestar.com/article/572699. Acesso em: 14 de dez. 2014.

RUSS, Joanna. The images of women in science fiction in images of women in fiction: feminist perspectives. S.K. Cornillon (ed.). Bowling Green, Ohio: Bowling Green University Popular Press, 1972.

SARLO, Beatriz. Tempo passado: cultura da memória e guinada subjetiva. São Paulo: Companhia das Letras; Belo Horizonte: UFMG, 2007.

SCHOLZ, Roswitha. O tabu da abstracção no feminismo: como se esquece o universal do patriarcado produtor de mercadorias. In: EXIT! Crise e crítica da sociedade das mercadorias. Berlim, n. 8, jul. 2011. Disponível em: http://obeco.planetaclix.pt/roswitha-scholz15.htm. Acesso em: 14 de dez. 2014.

SCHOLZ, Roswitha. O valor é o homem: teses sobre a socialização pelo valor e a relação entre os sexos. Tradução portuguesa de Der Wert ist der Mann (In: Krisis n. 12, pp. 19-52, 1992) por José Marcos Macedo. In: Novos Estudos. CEBRAP. São Paulo, n. 45, pp. 15-36, jul. 1996. Disponível em http://obeco.planetaclix.pt/rst1.htm. Acesso em: 14 de dez. 2014.

SCHWARZ, Roberto. Ao vencedor as batatas: forma literária e processo social nos inícios do romance brasileiro. São Paulo: Duas Cidades, 1977.

SCHWARZ, Roberto. Duas meninas. São Paulo: Companhia das Letras, 1994.

SCHWARZ, Roberto. Que horas são? São Paulo: Companhia das Letras, 1989. 
SCHWARZ, Roberto. Um mestre na periferia do capitalismo: Machado de Assis. São Paulo: Duas Cidades, 2000.

SCOTT, Joan, Gênero: uma categoria útil para a análise histórica. Trad. Christine Rufino Dabat e Maria Betânia Ávila. [S.l.: s.n., entre 1995 e 2014]. Disponível em: http://www.dhnet.org.br/direitos/textos/generodh/gen_categoria.html. Acesso em: 14 de dez. 2014.

SILVA, Aristóteles de Almeida. O capitalismo tardio e sua crise: estudo das interpretações de Ernest Mandel e a de Jürgen Habermas. Dissertação de mestrado em Sociologia. Campinas: Unicamp, 2012.

SKORUPA, Francisco Alberto. Viagem às letras do futuro: extratos de bordo da ficção científica brasileira, 1947-1975. Curitiba: Tetravento, 2002.

SOARES, Marcos César de Paula. As figurações do falso em O Agente Secreto. Tese de doutorado apresentada ao Departamento de Letras Modernas, FFLCH-USP, 2000.

SOARES, Marcos. O projeto inacabado de Cidadão Kane. In: SOARES, Marcos; CEVASCO, Maria Elisa (eds.). Crítica cultural materialista. São Paulo: Humanitas, 2008.

SODRÉ, Muniz. A ficção no tempo: análise da narrativa de science fiction. Petrópolis: Vozes, 1973.

SPIVAK, Gayatri Chakravorty. Pode o subalterno falar? Trad. Sandra Regina Goulart Almeida, Marcos Pereira Feitosa e André Pereira Feitosa. Belo Horizonte: UFMG, 2010.

STAELS, Hilde. Margaret Atwood's The Handmaid's Tale: resistance through narrating. In: English Studies, volume 76, Issue 5, 1995.

SUlliVAN, Rosemary. The Red Shoes: Margaret Atwood Starting Out, Toronto: HarperCollins, 1998. 
SUVIN, Darko. Parables of De-Alienation: Le Guin's Widdershins Dance. In Science Fiction Studies 7, Vol. 2, Nov. 1975. Disponível em http://www.depauw.edu/sfs/backissues/7/suvin7art.htm. Acesso em: 13 de dez. 2014.

SUVIN, Darko. An interview with Darko Suvin: science fiction and history, cyberpunk, russia. In: Science Fiction Studies. Greencastle, IN, vol. 18, n. 54, p. 253 261, jul. 1991.

SUVIN, Darko. Metamorphoses of science fiction: on the poetics and history of a literary genre. New Haven: Yale University, 1979.

SUVIN, Darko. The SF novel in 1969. In: BLISH, James (org). Nebula Award Stories Five. London: Gollancz, 1970.

TAVARES, Bráulio. O que é ficção científica. São Paulo: Brasiliense, 1986. Coleção Primeiros Passos.

Thompson, Edward P. The making of the English working class. London, Penguin, 1991.

TILLACK, Tim. Essay: the critical reception of Ursula K. Le Guin's "Left Hand of Darkness". Disponível em:

http://knowledgeeater.blogspot.com.br/2011_10_01_archive.html. Acesso em: 14 de dez. 2014.

TOLAN, Fiona. Margaret Atwood: feminism and criticism. Amsterdam: Rodopi B. V., 2007.

VASCONCELOS, Sandra Guardini. Formação do Romance Brasileiro: 1808-1860 (Vertentes Inglesas). Ensaio. Campinas, [20-]. Disponível em http://www.unicamp.br/iel/memoria/Ensaios/Sandra/sandra.htm. Acesso em: 14 de dez. 2014.

WATSON, Ian. Le Guin's Lathe of heaven and the role of Dick: the false reality as mediator. In: Science Fiction Studies. Greencastle, IN, n. 5, vol. 2, parte 1, mar. 1975. 
Nota n. 4. Disponível em: http://www.depauw.edu/sfs/backissues/5/watson5art.htm. Acesso em: 13 de dez. 2014.

WATSON, Ian. Le Guin's Lathe of Heaven and the Role of Dick: The False Reality as Mediator. Science Fiction Studies 2.1, p. 67-75, 1975.

WATT, Ian. A ascensão do romance: estudos sobre Defoe, Richardson e Fielding. São Paulo: Companhia das Letras, 2007.

WEYANT, Curtir. Secondary Bibliography: Left Hand of Darkness. Disponível em http://www.curtisweyant.com/scholarship/biblio/secondary-bibliography-left-hand-ofdarkness. Acesso em: 14 de dez. 2014.

WILLIAMS, Raymond. Base e superestrutura na teoria cultural marxista. Revista USP, São Paulo, n.65, p. 210-224, março/maio 2005. Disponível em http://www.revistas.usp.br/revusp/article/viewFile/13448/15266. Acesso em: 14 de dez. 2014.

WILLIAMS, Raymond. Marxism and Literature. Oxford: Oxford University, 1977.

WILLIAMS, Raymond. The English Novel: from Dickens to Lawrence. London: Chatto \& Windus, 1970.

WILLIS, Susan. Cotidiano: para começo de conversa. São Paulo: Graal, 1997. ZIZEK, Slavoj. First as tragedy, then as farce. London: Verso, 2009. 